\title{
Convergent, Stereoselective Synthesis of the GHIJ fragment of Brevetoxin A
}

Michael T. Crimmins, * J. Lucas Zuccarello, Pamela A. Cleary, Jonathan D. Parrish

Venable and Kenan Laboratories of Chemistry, University of North Carolina at Chapel

Hill, Chapel Hill, North Carolina, 27599

Supporting Information (2 of 2): ${ }^{1} \mathrm{H}$ and ${ }^{13} \mathrm{C}$ NMR spectra for compounds $\mathbf{6}-\mathbf{1 5}, \mathbf{1}$,

16-20, 2, 3, 21, 4, 22-25, 5; ${ }^{1} \mathrm{H}$ NMR spectrum for diol derivative of compound 5; and ${ }^{1} \mathrm{H}$,

${ }^{13} \mathrm{C}$, COESY, and NOESY NMR spectra for the diacetate derivative of compound $\mathbf{5}$ 


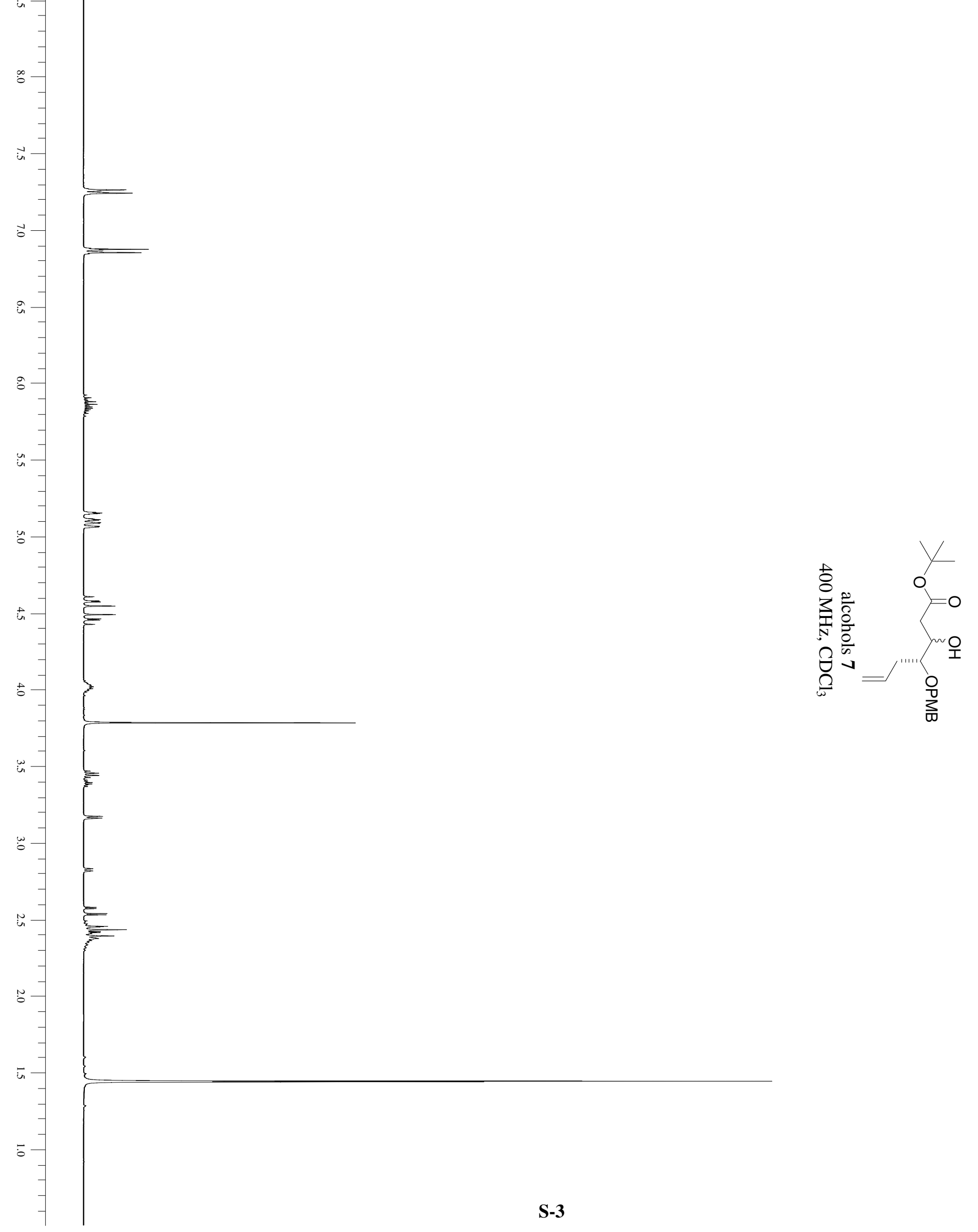



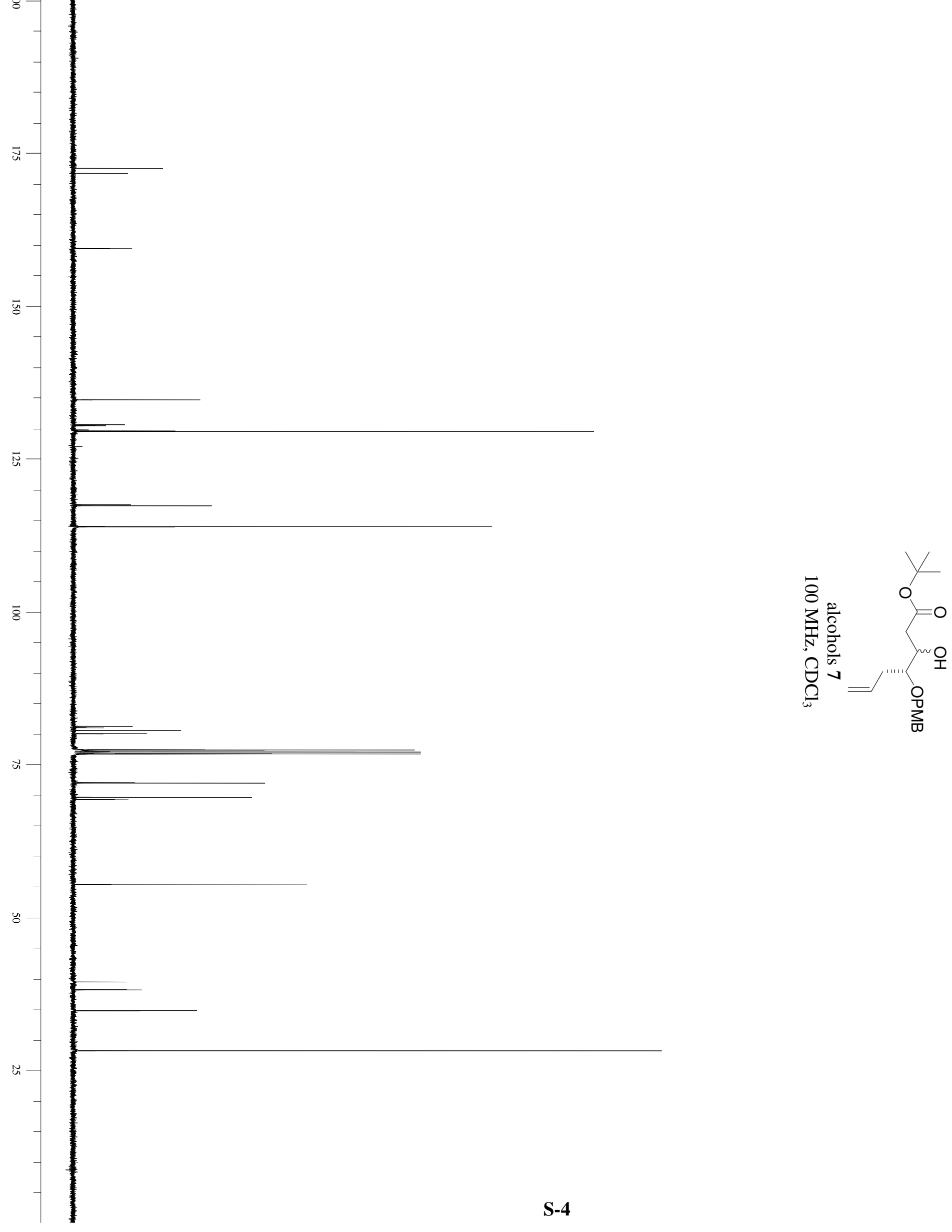


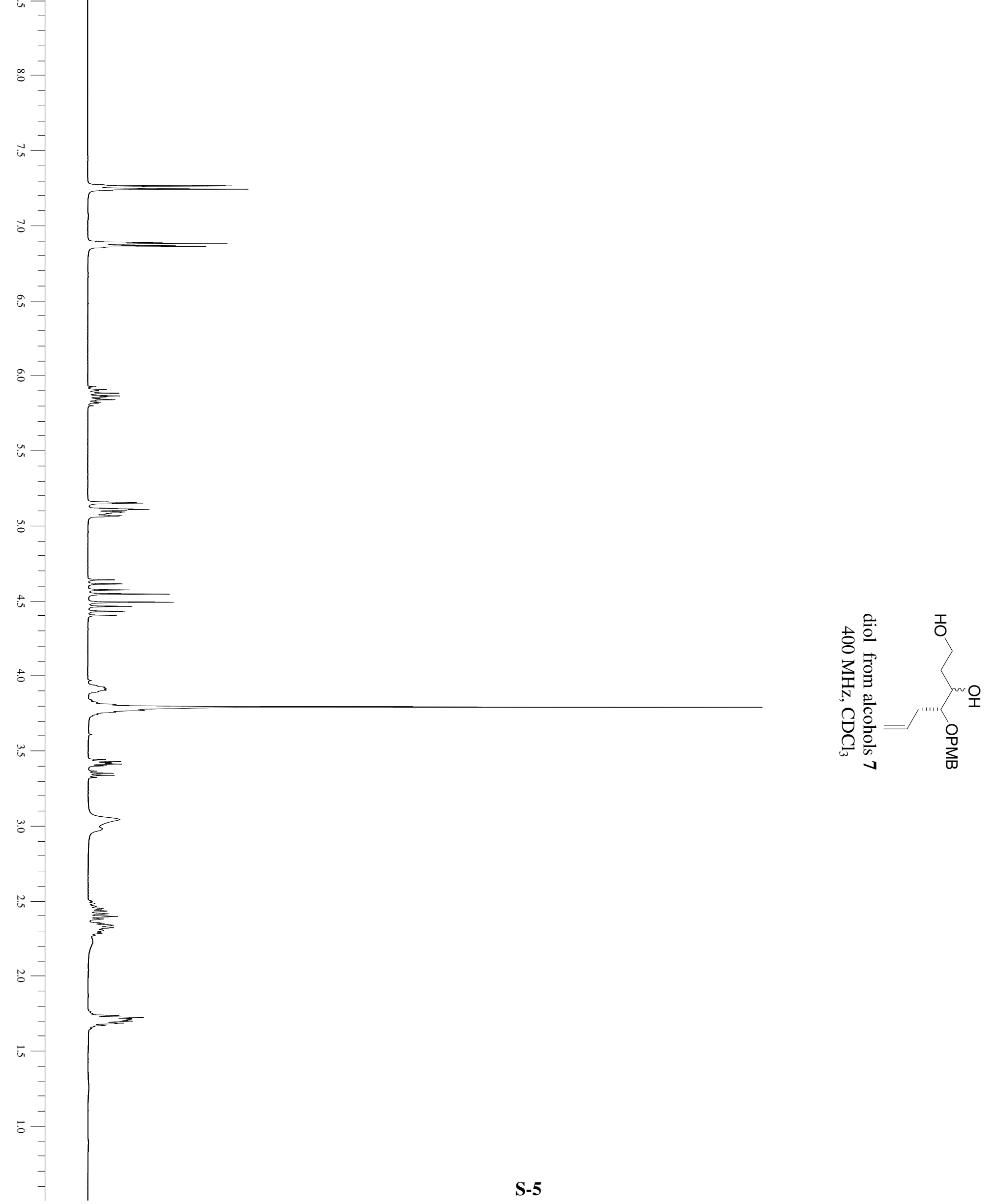




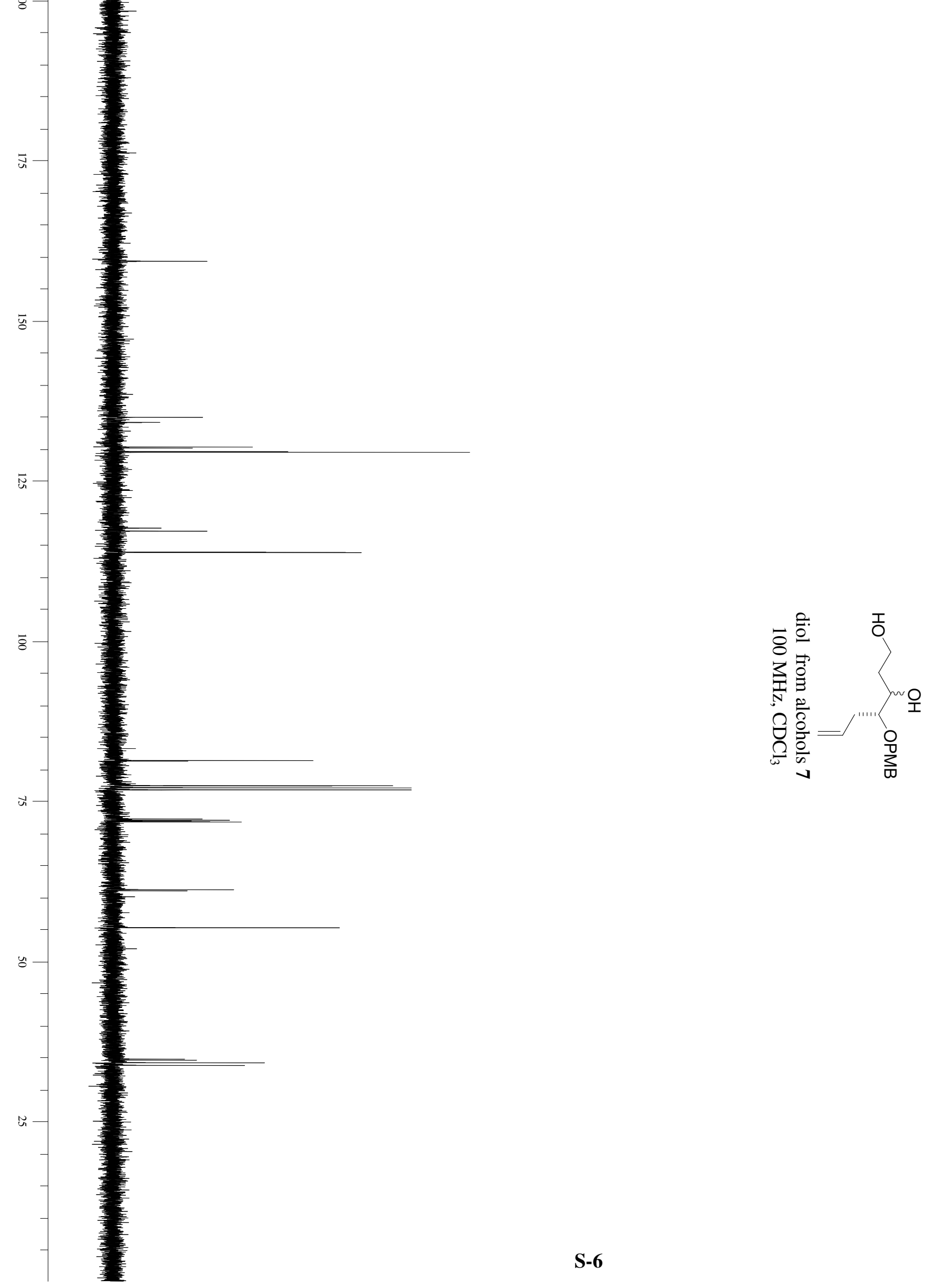




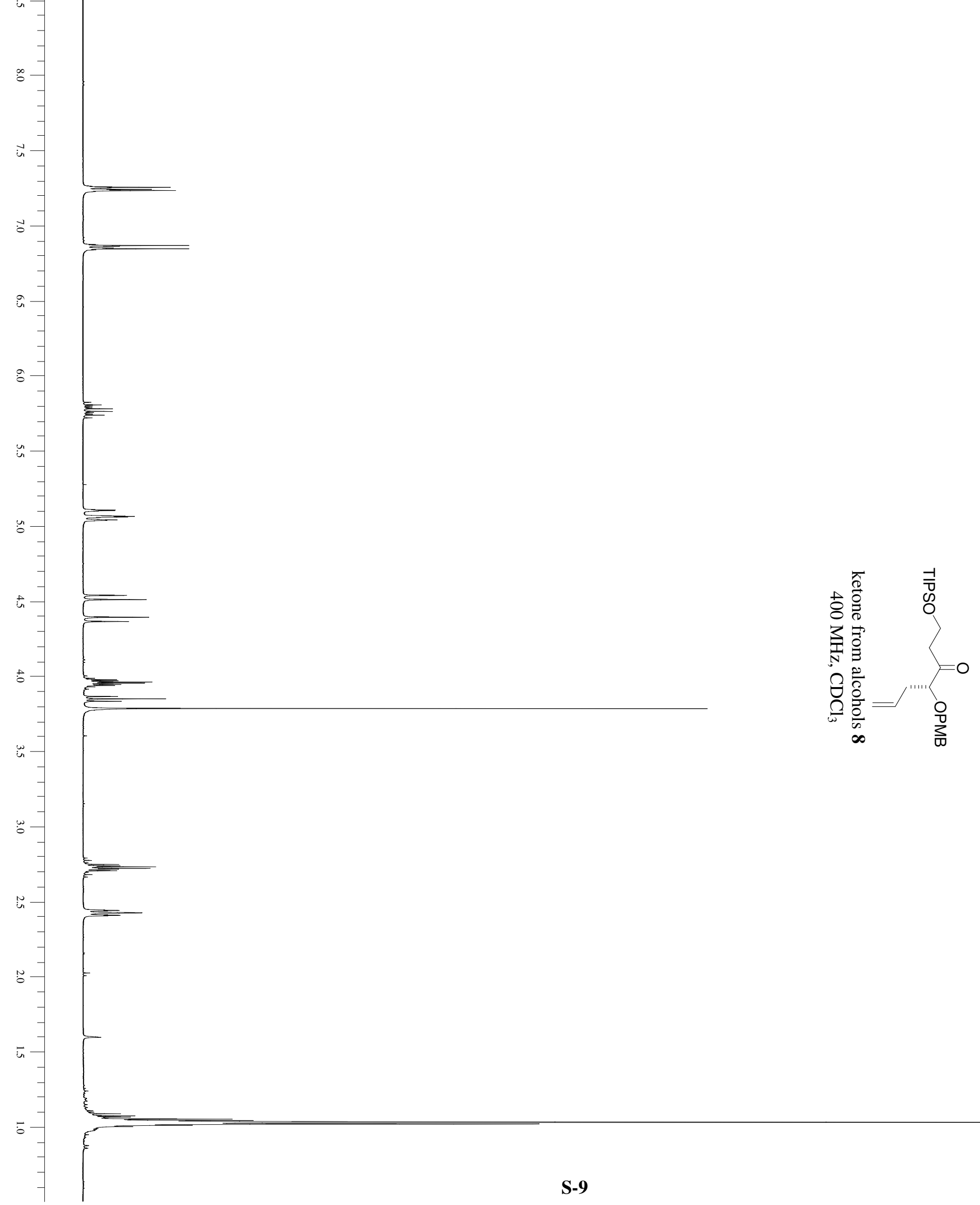




$$
=
$$




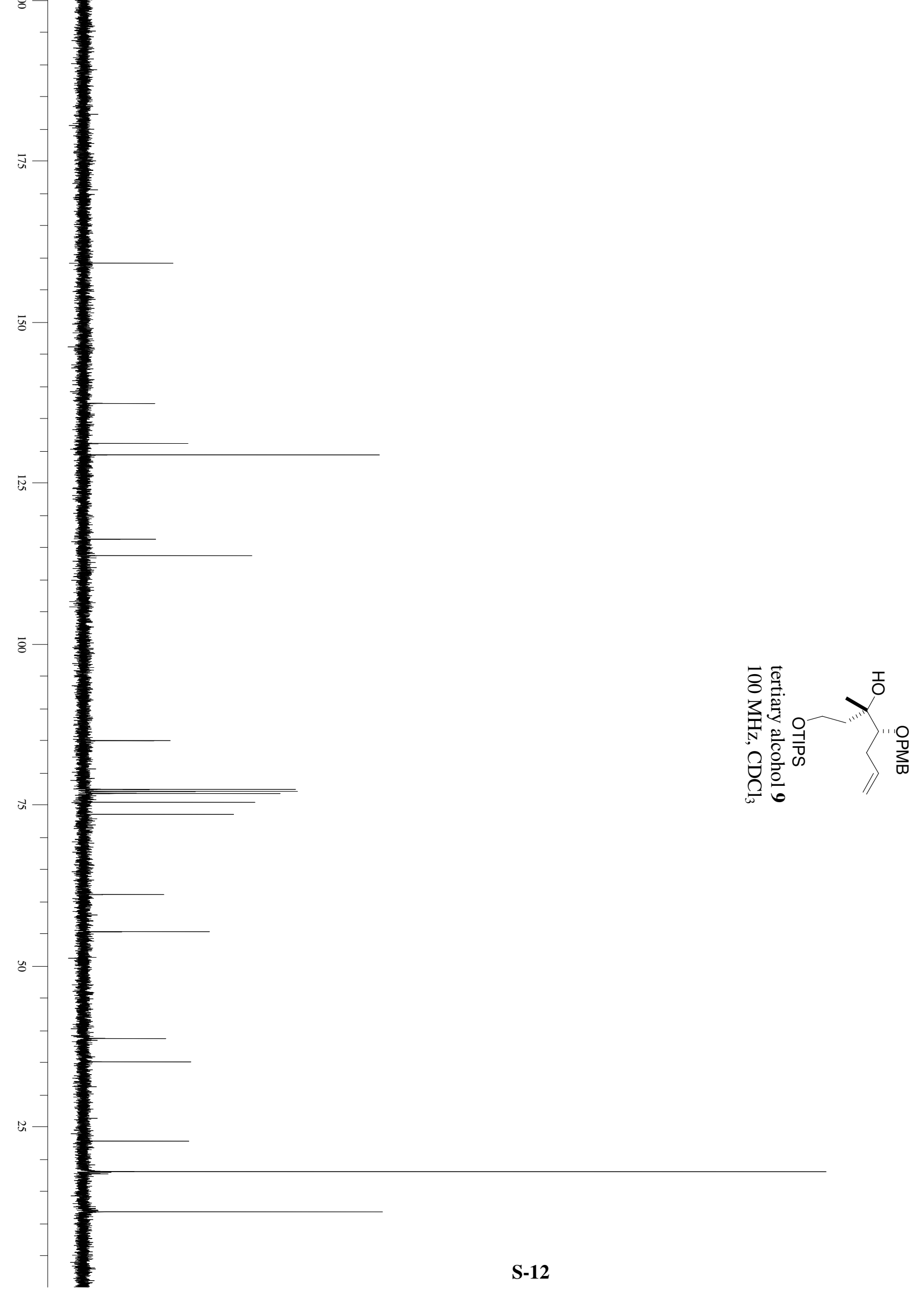




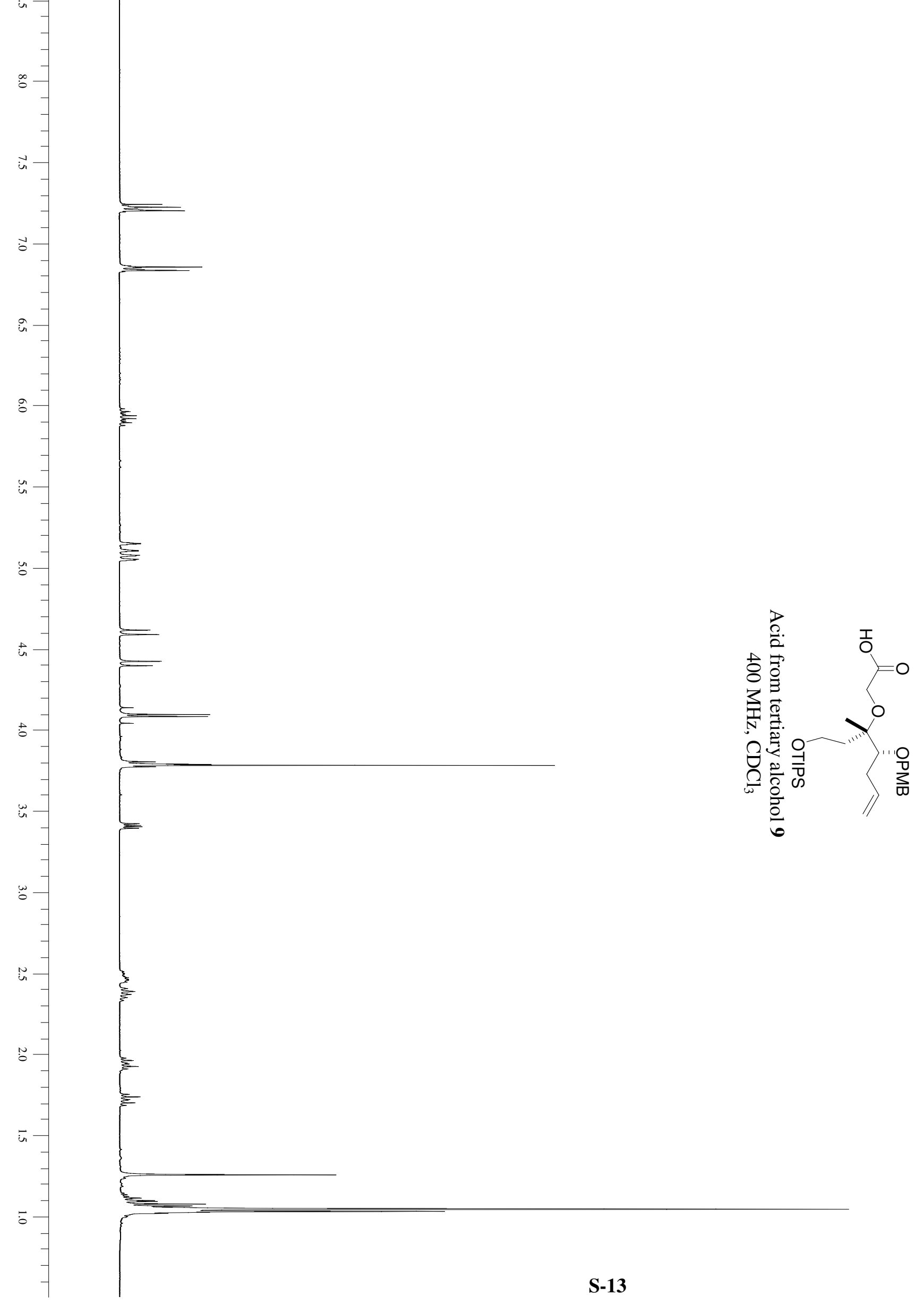




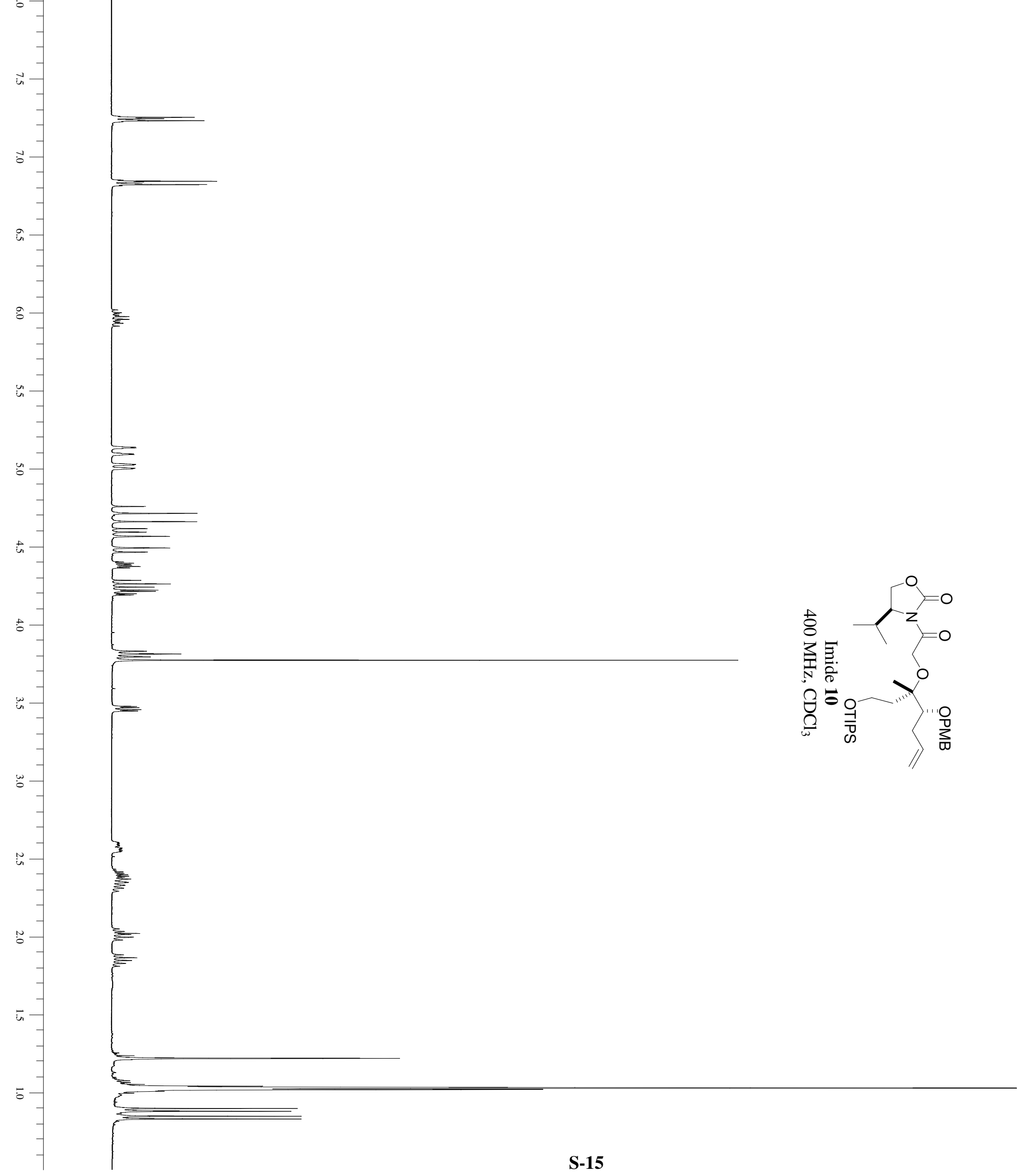




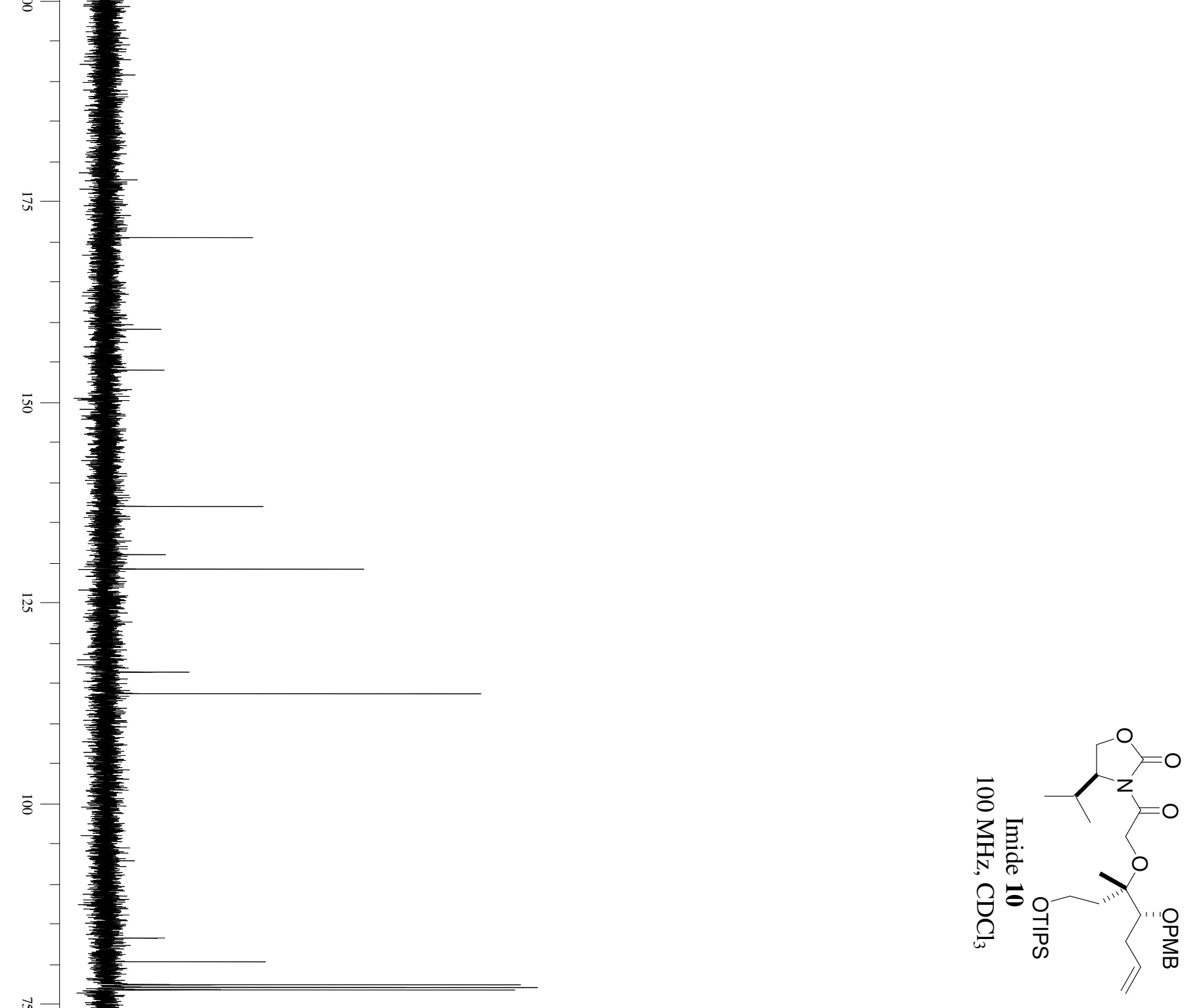

S-16 


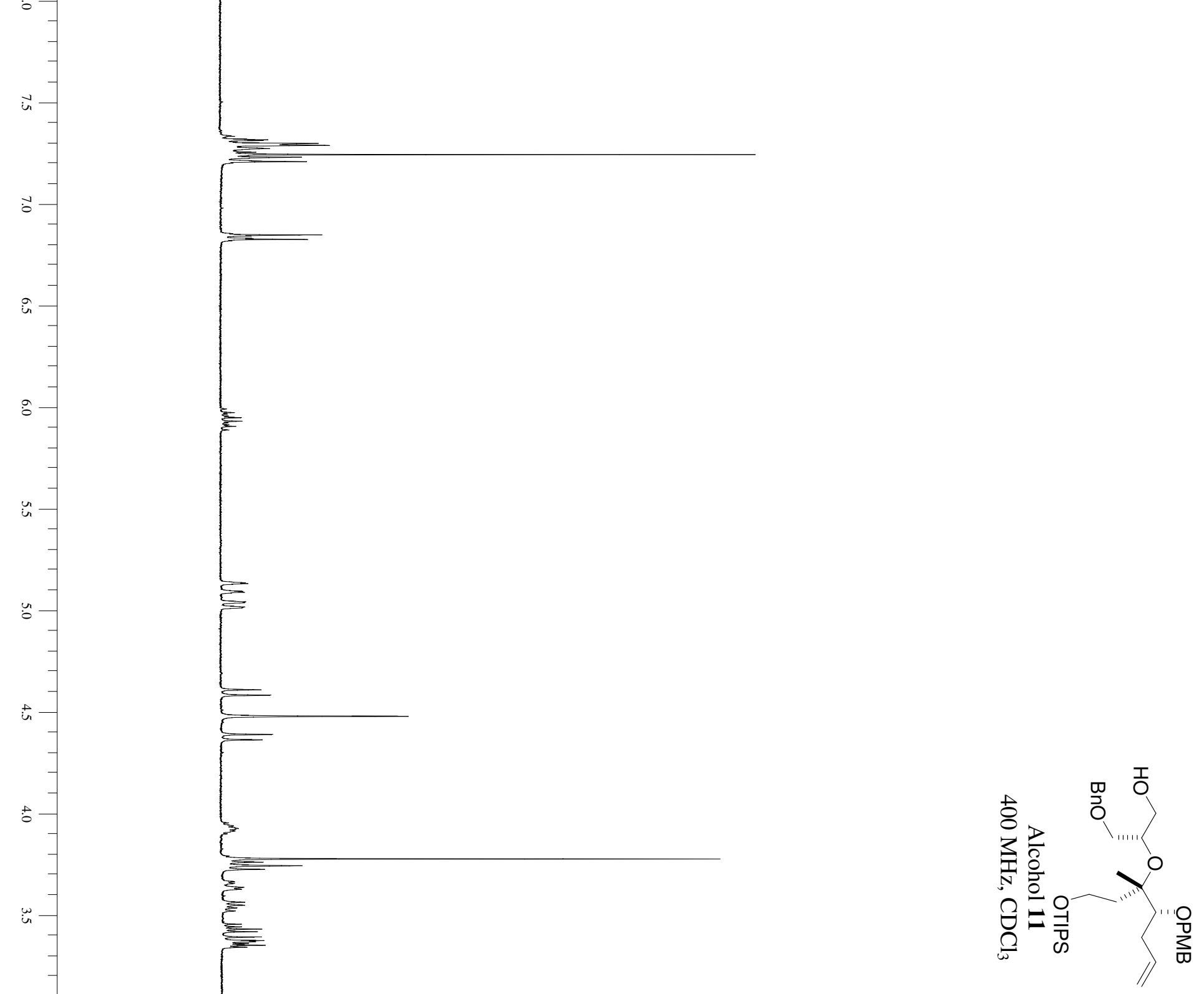




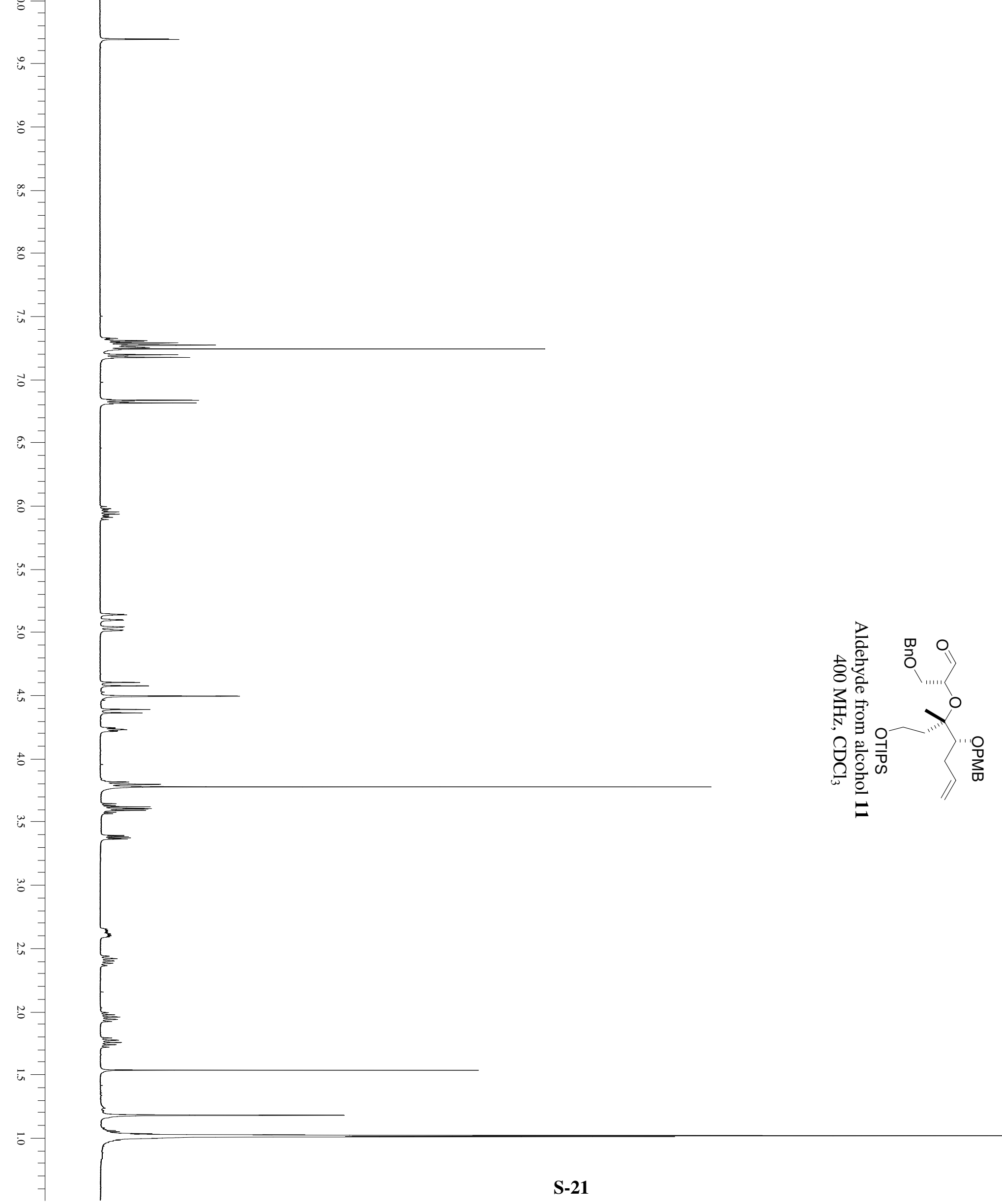




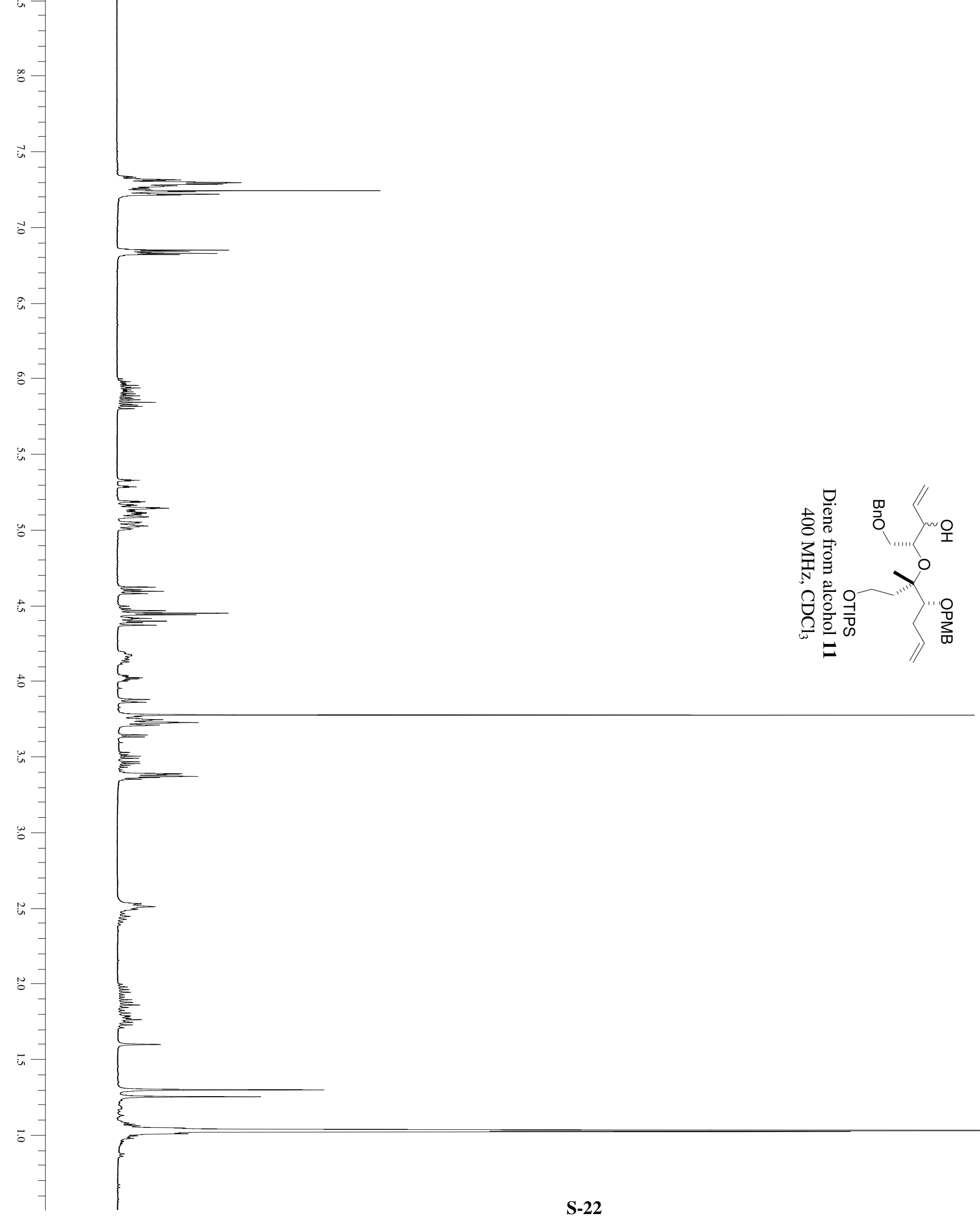




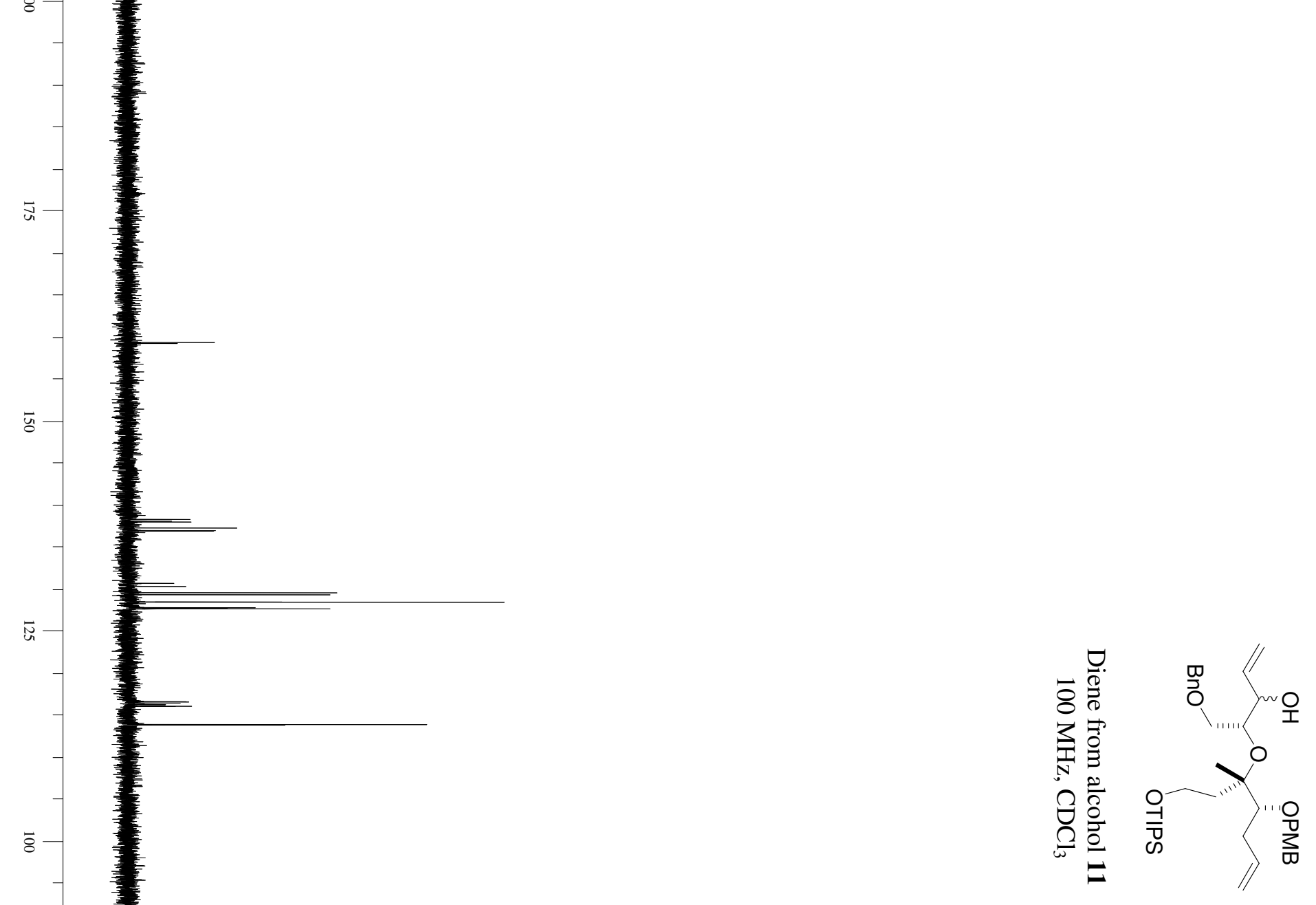




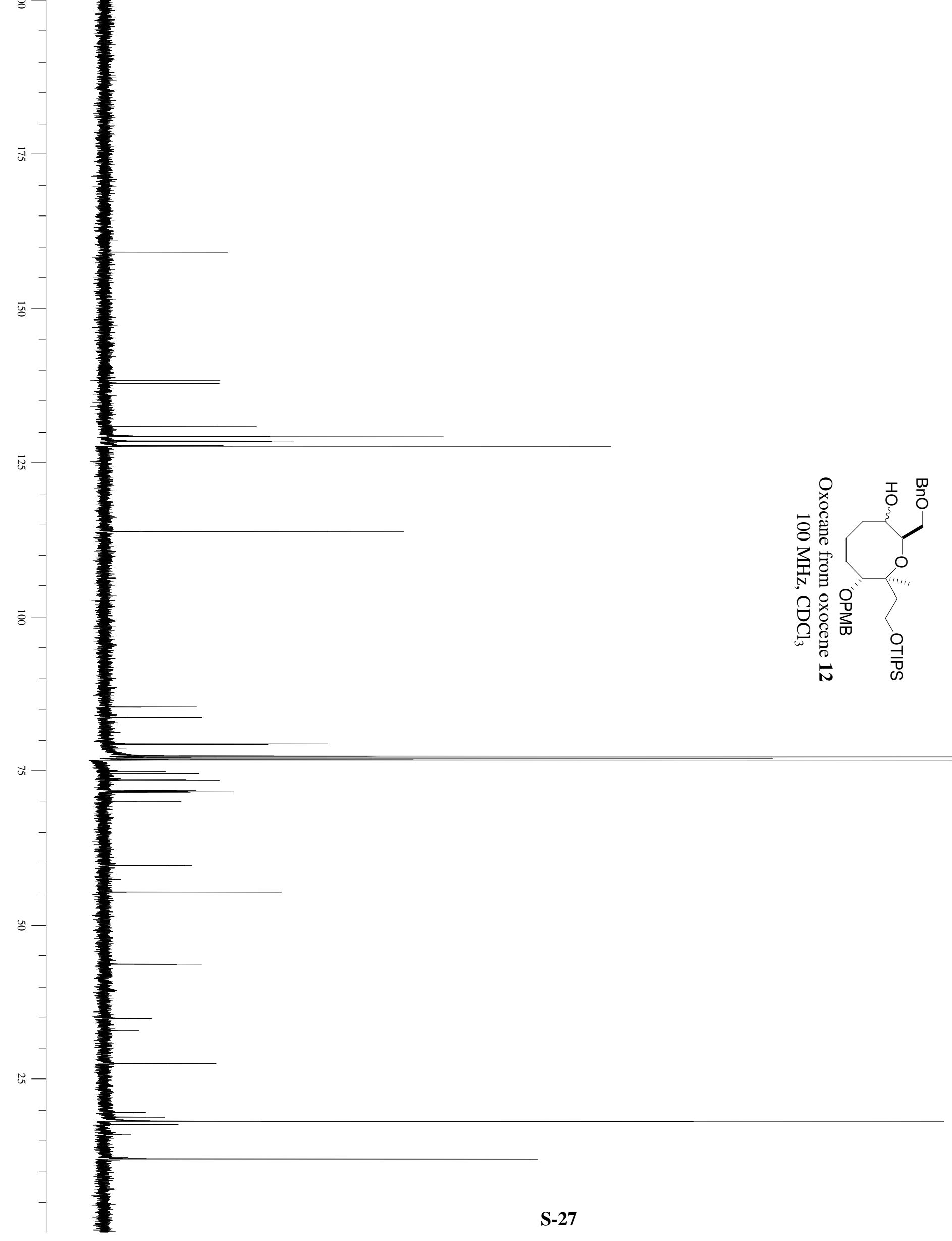




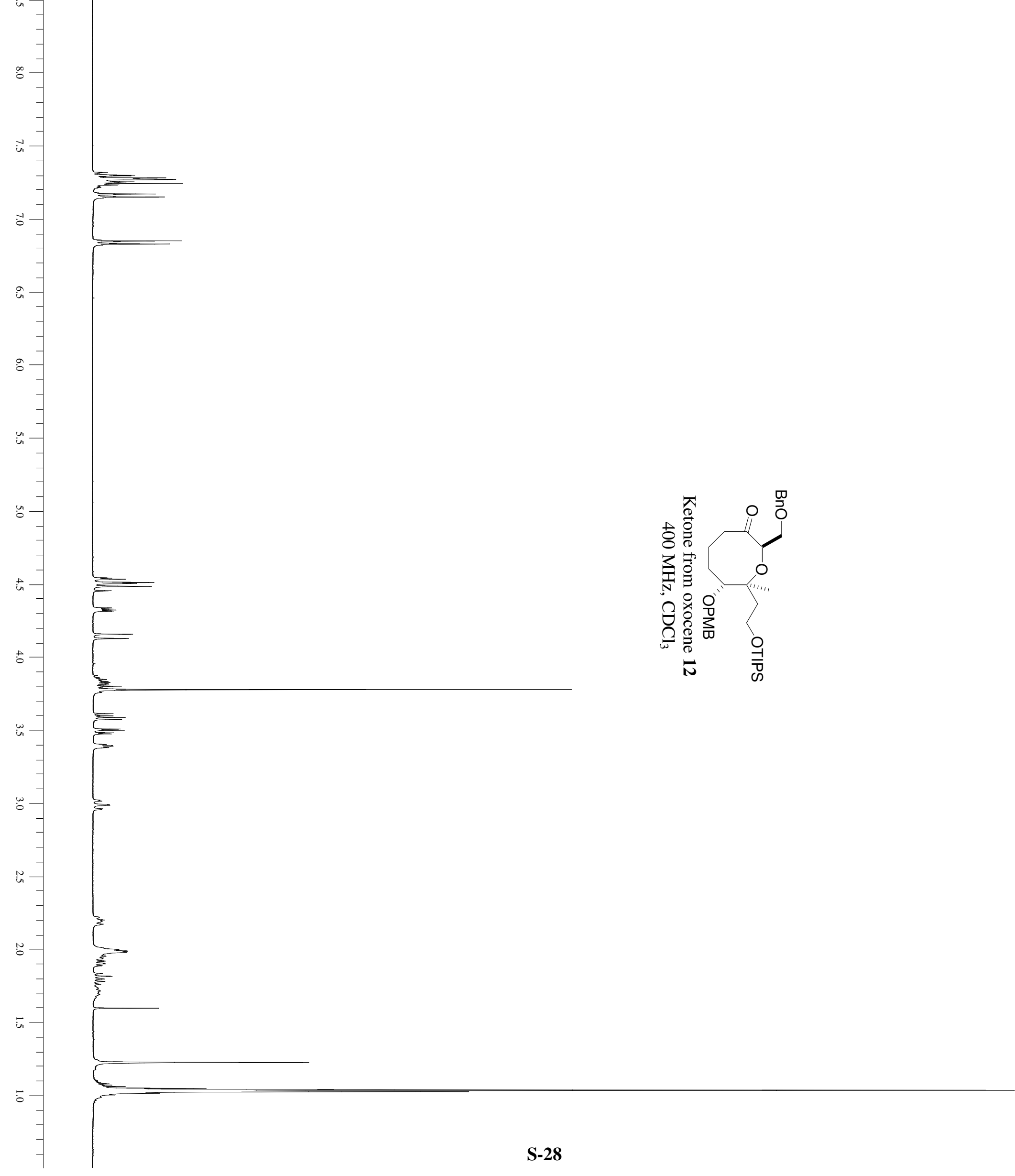




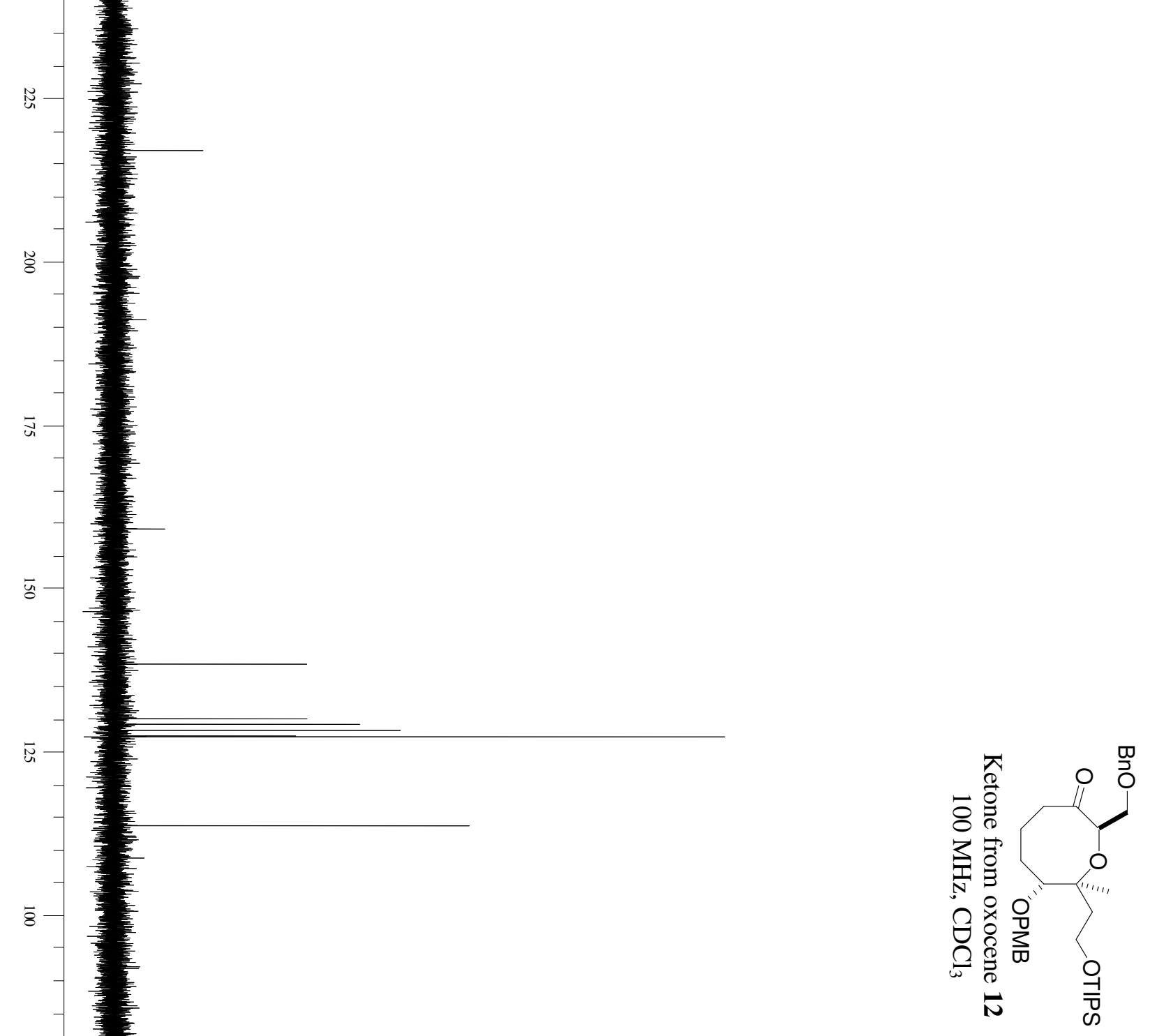




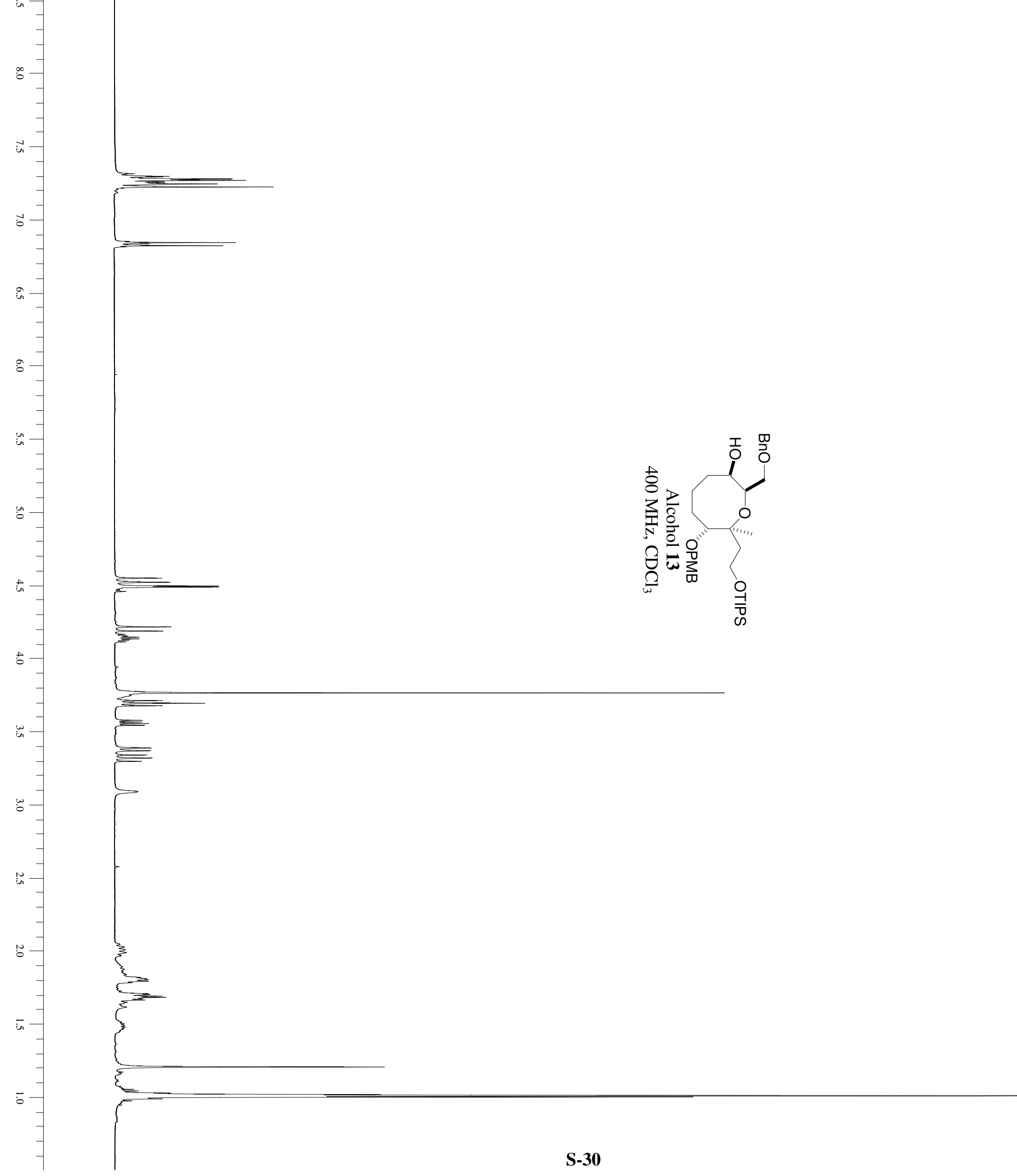




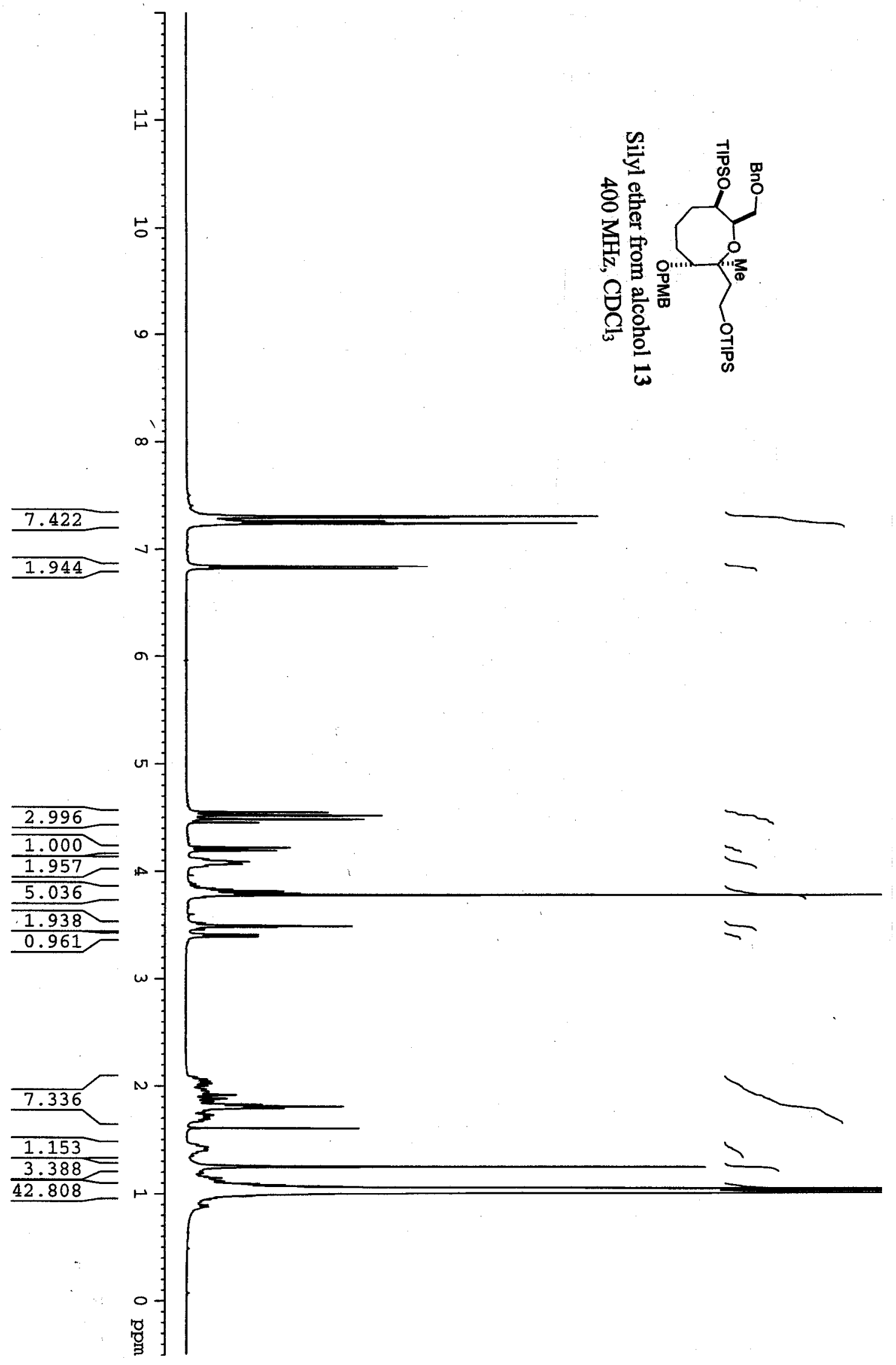




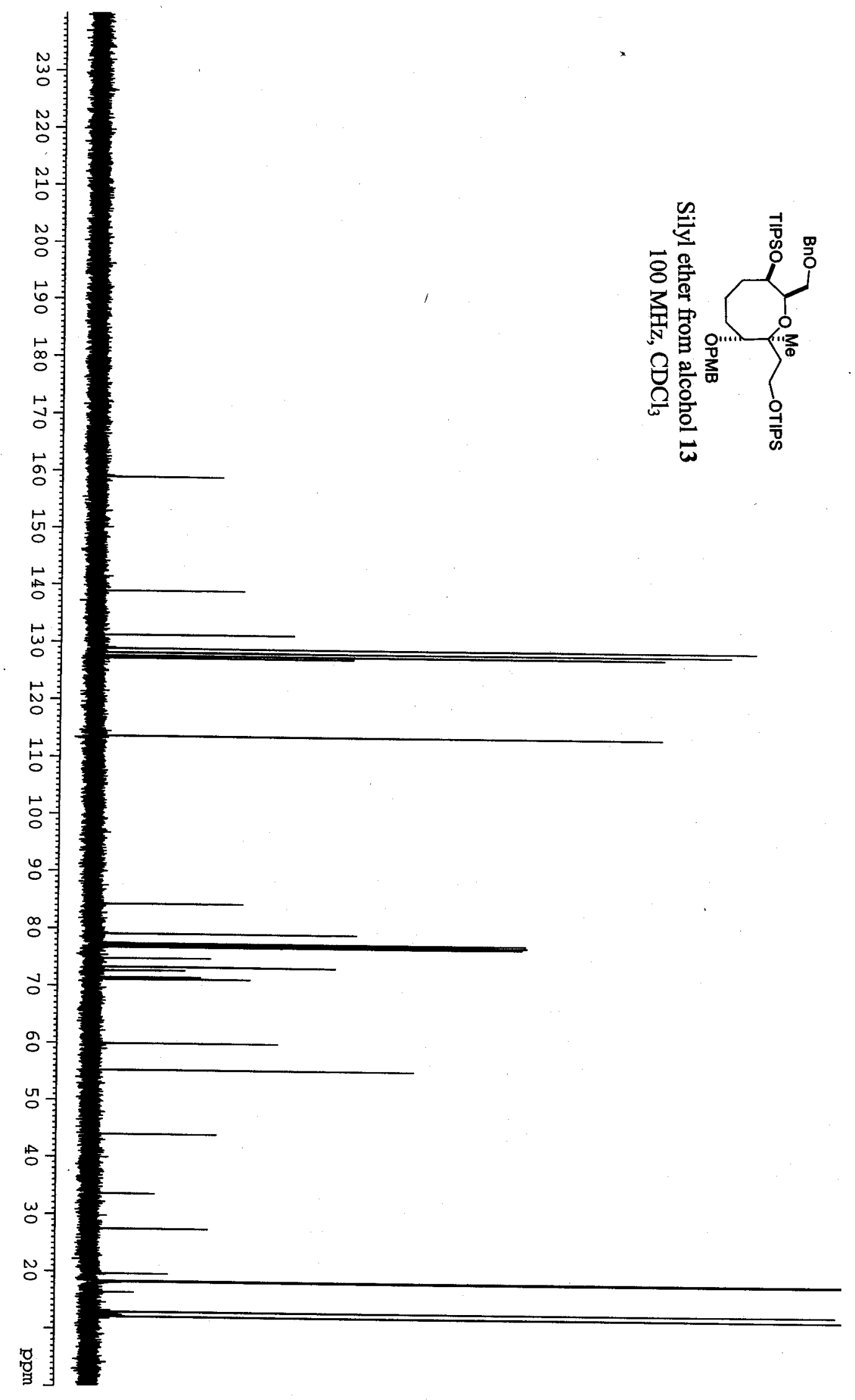




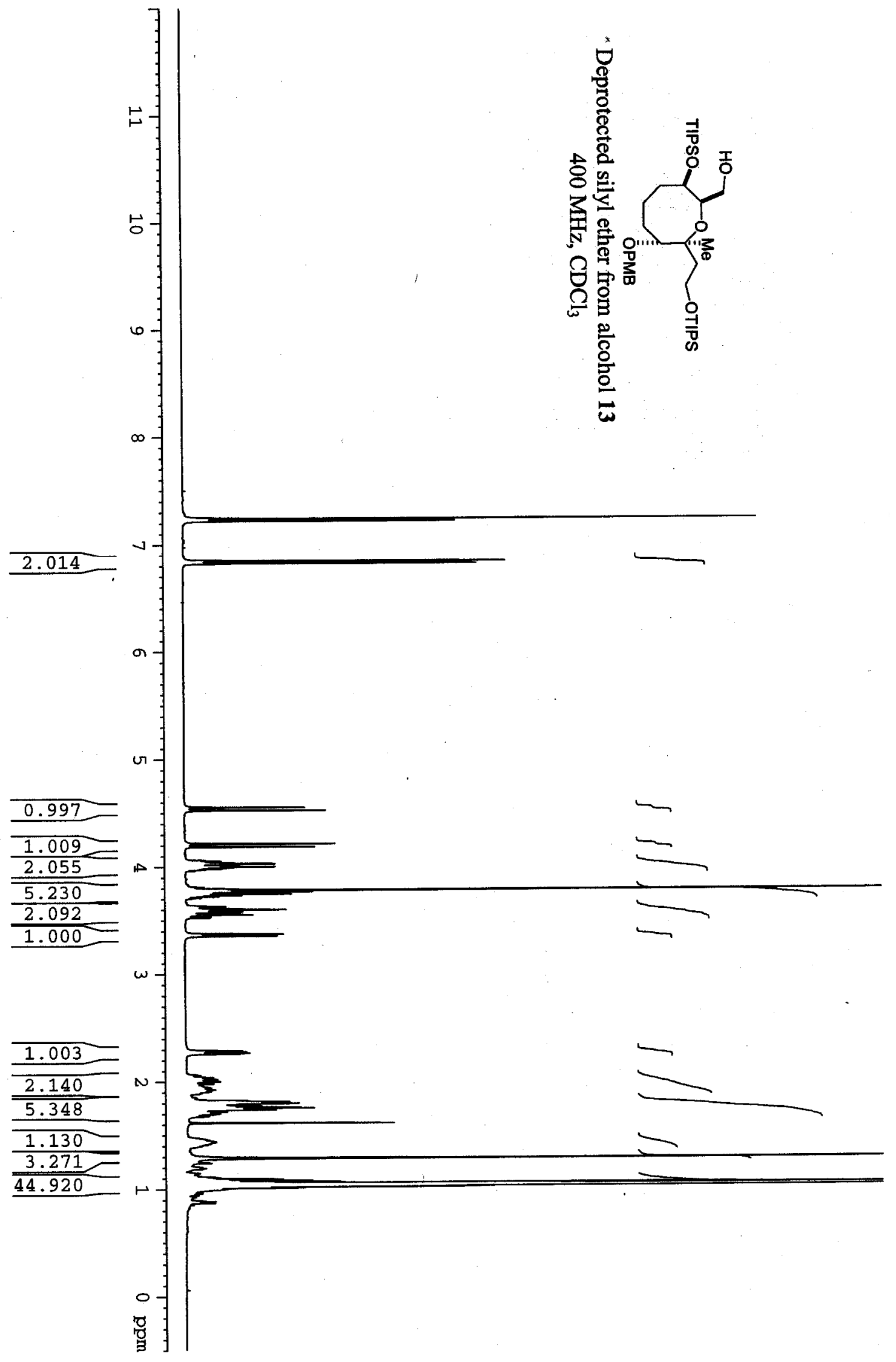




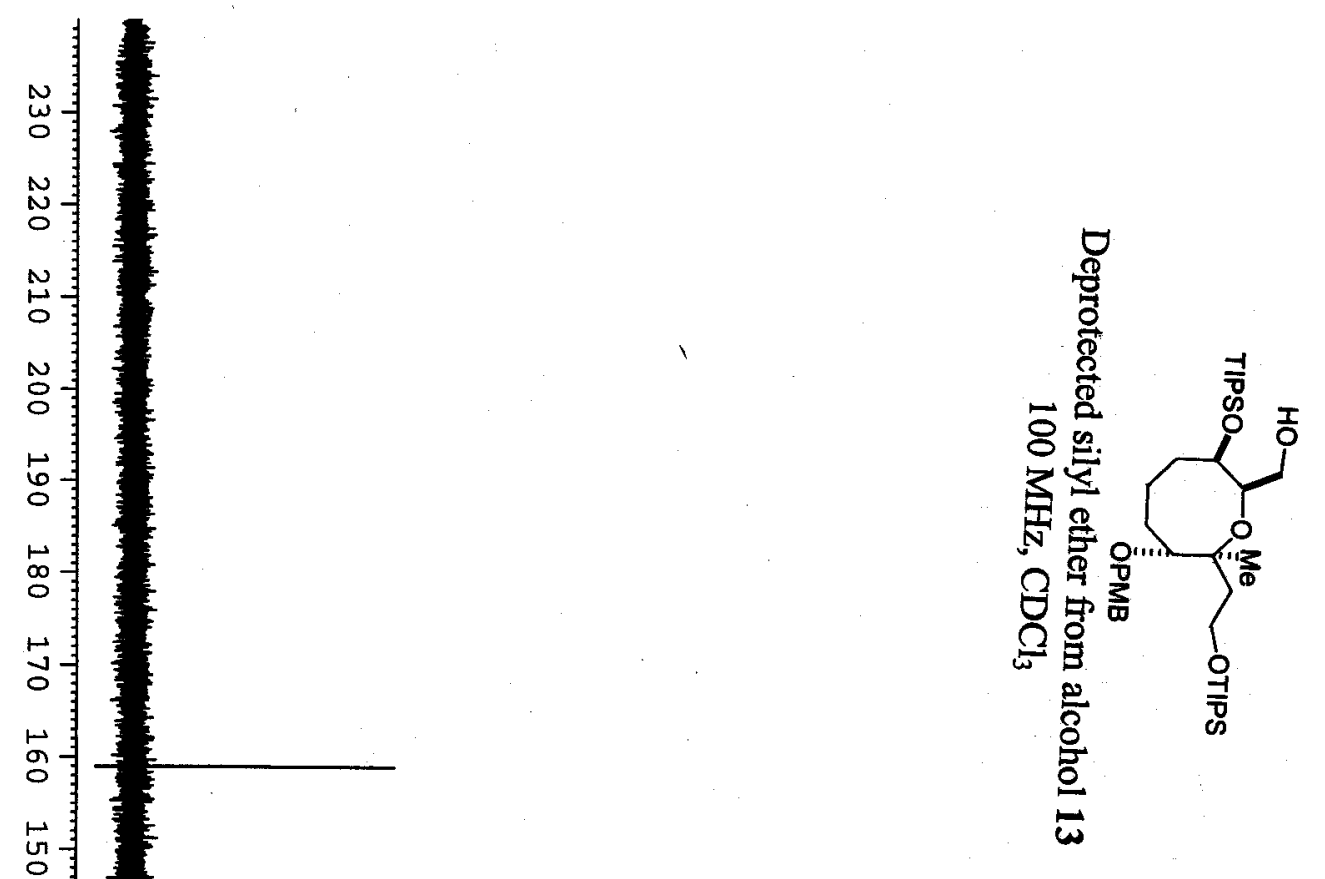




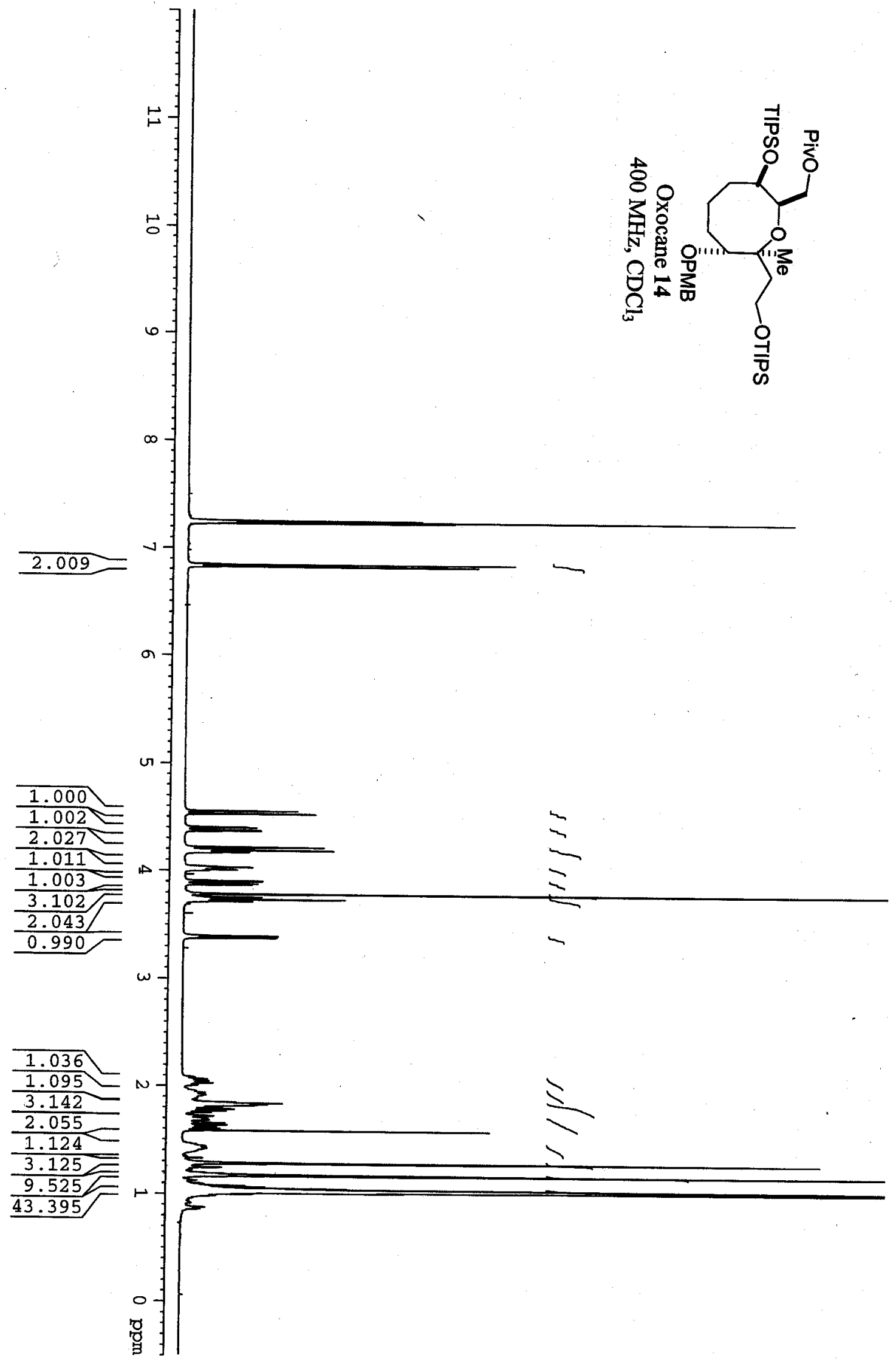




$$
\text { L }
$$




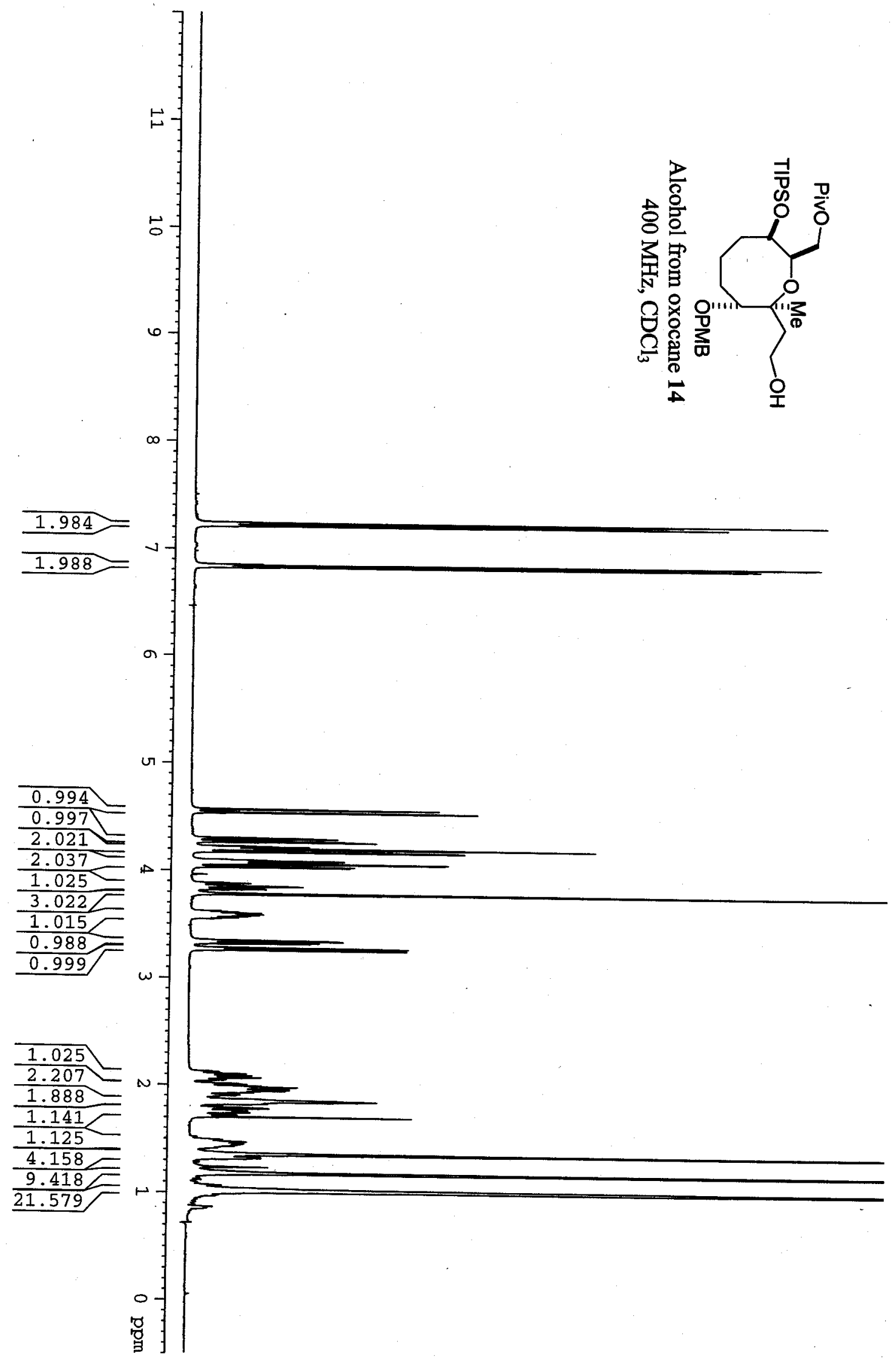




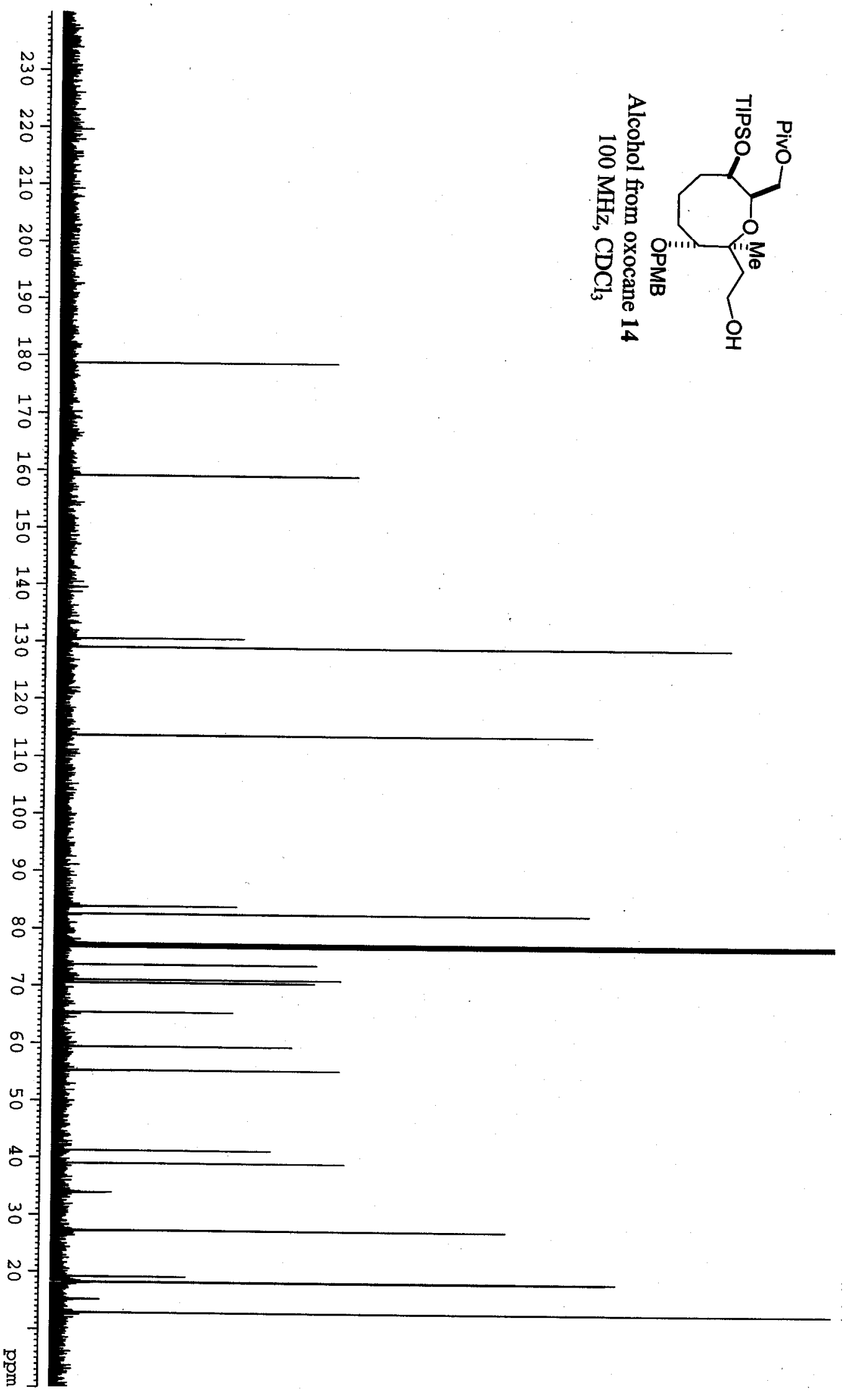




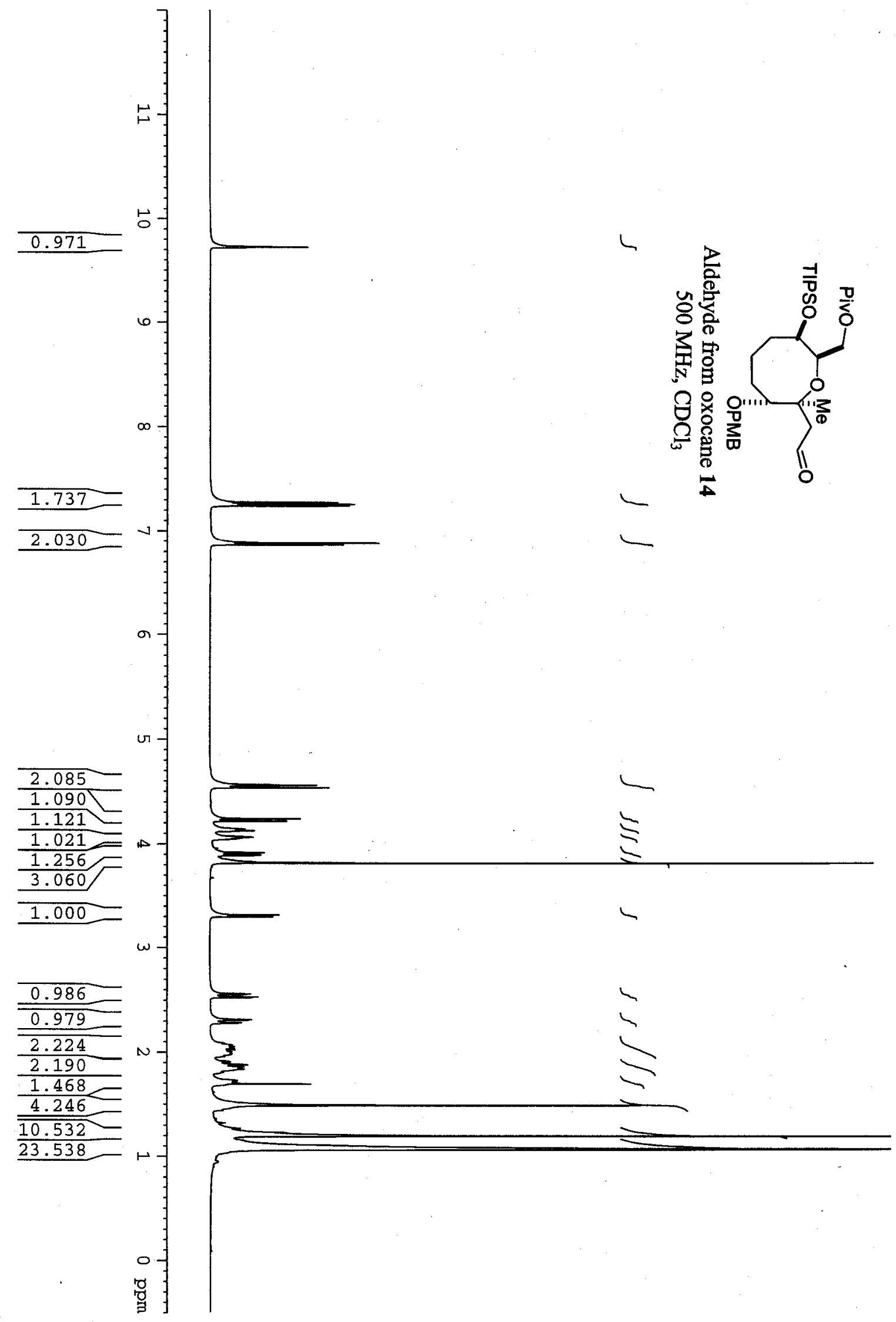




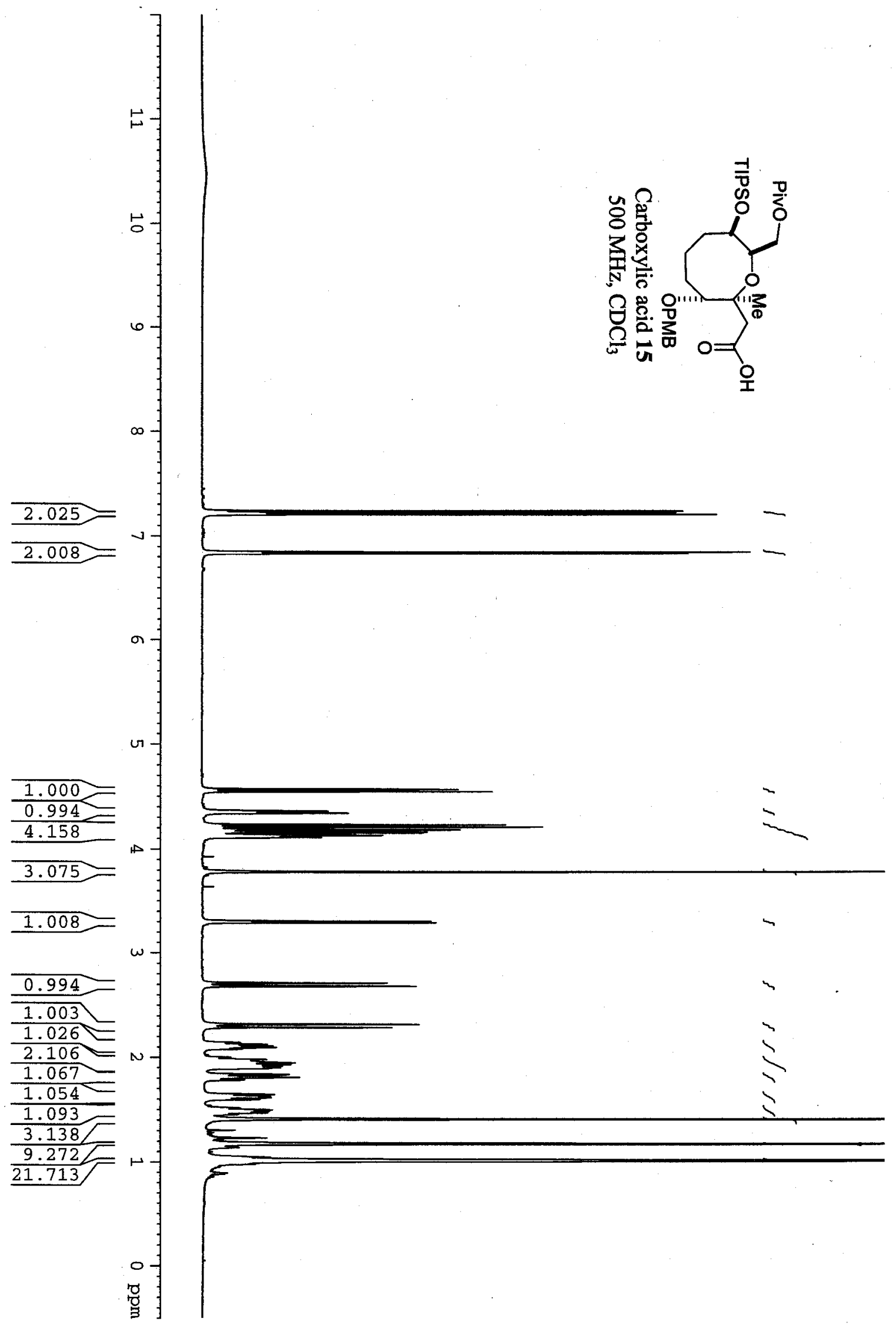




$$
\text { | }
$$




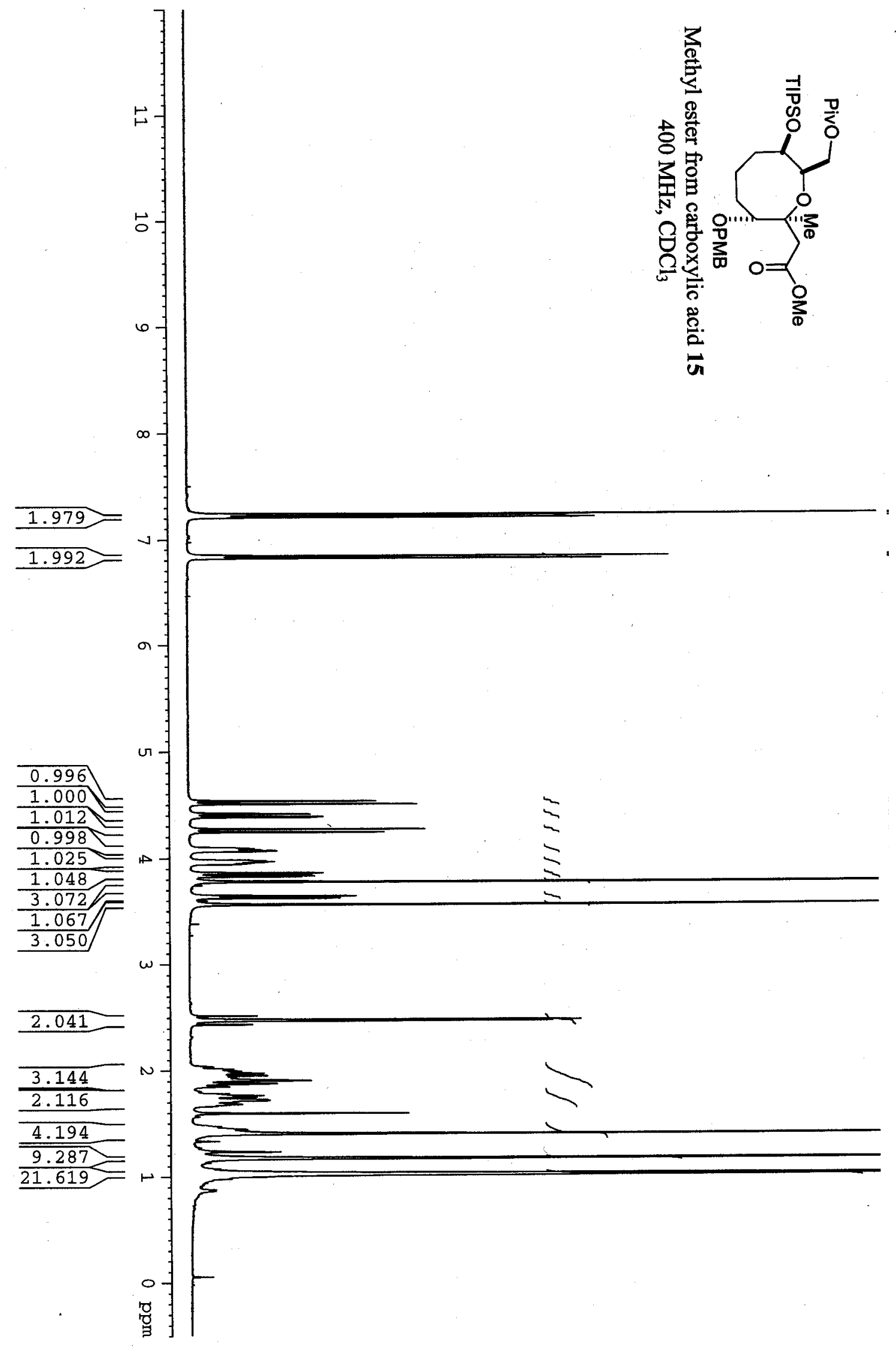




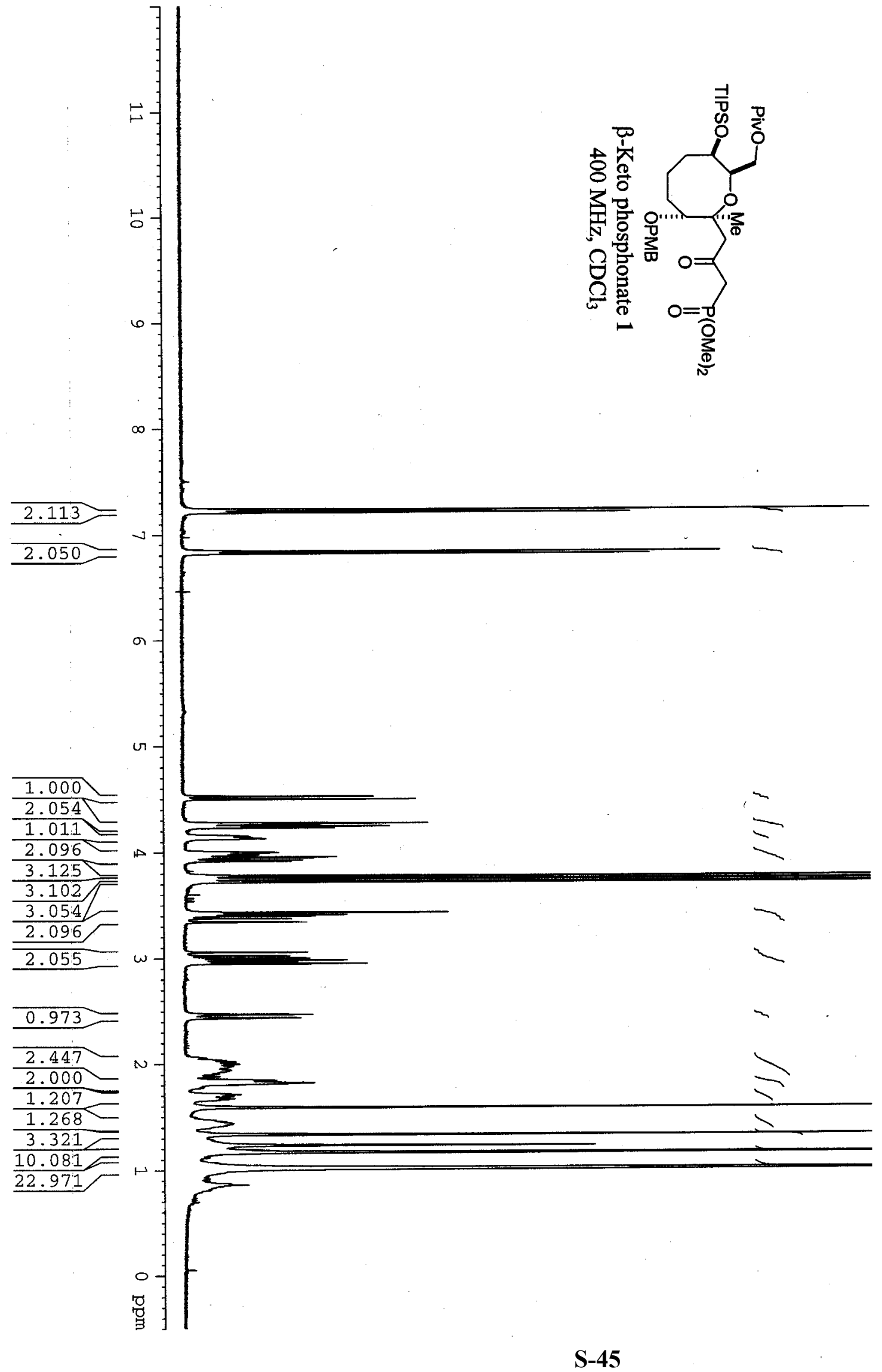




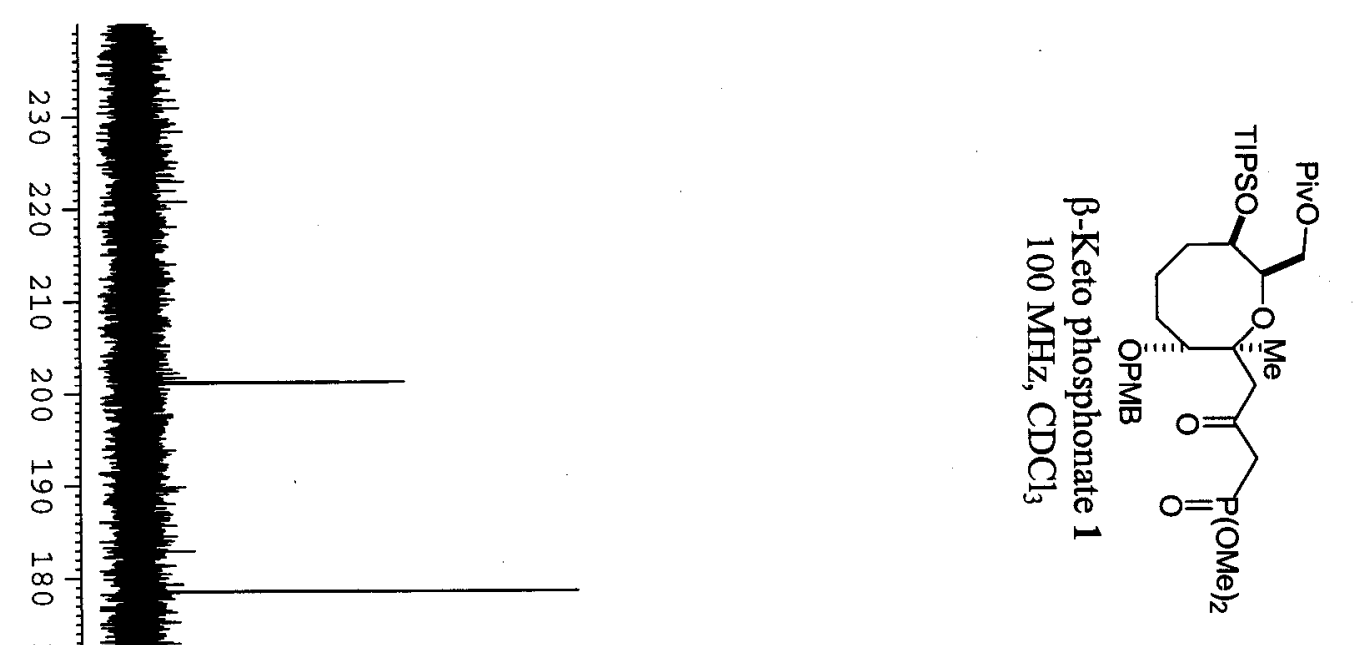




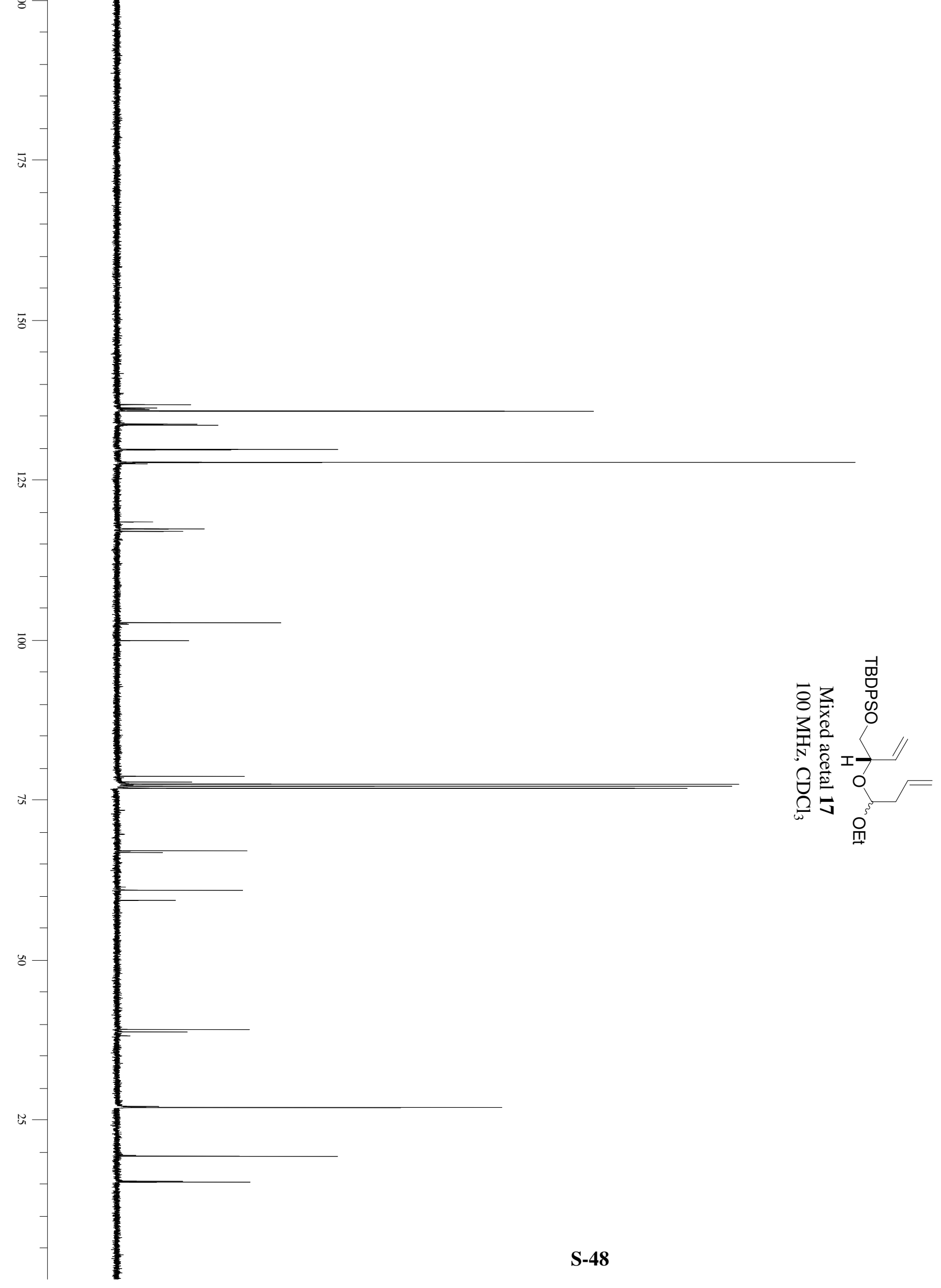




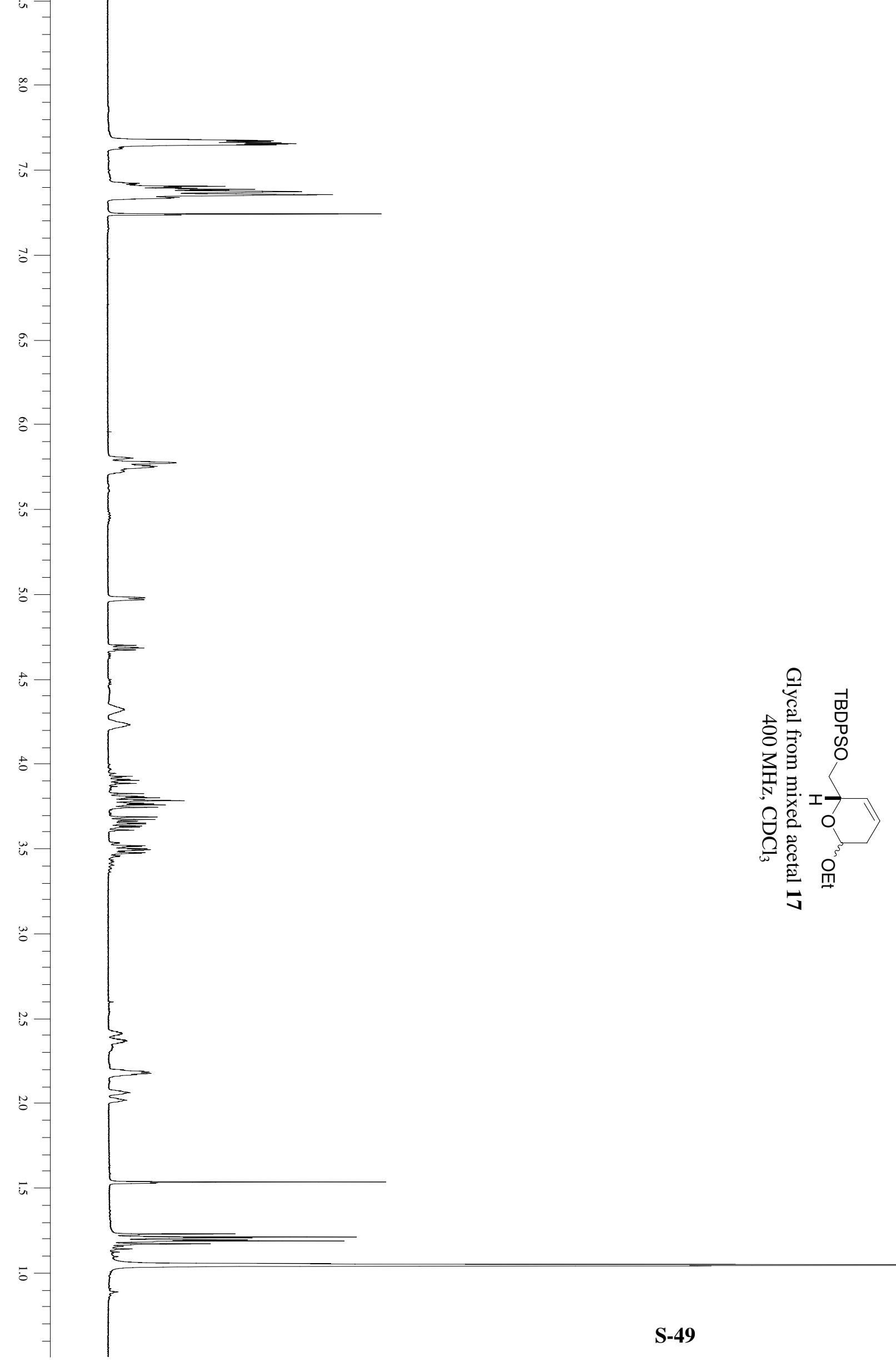




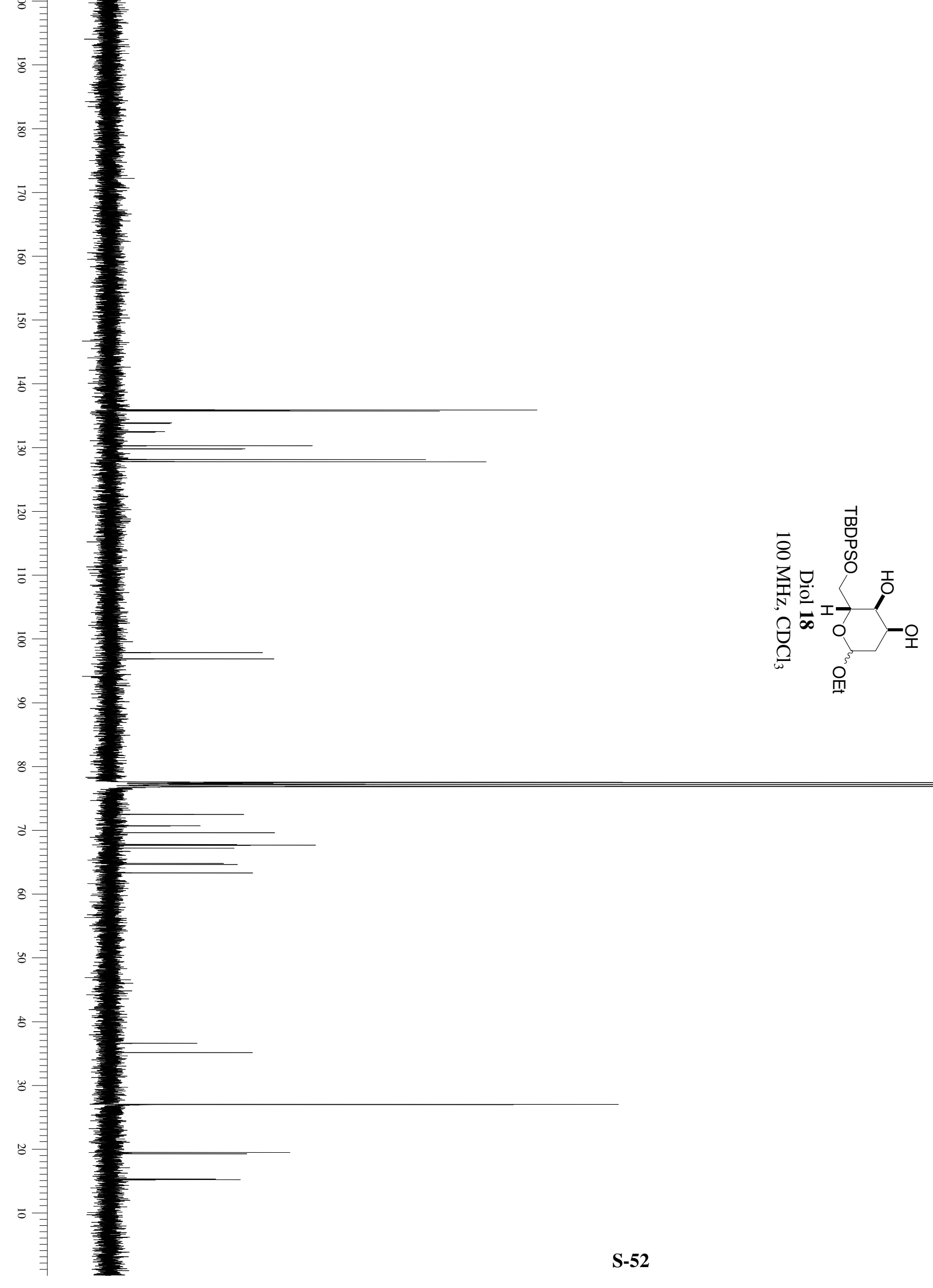




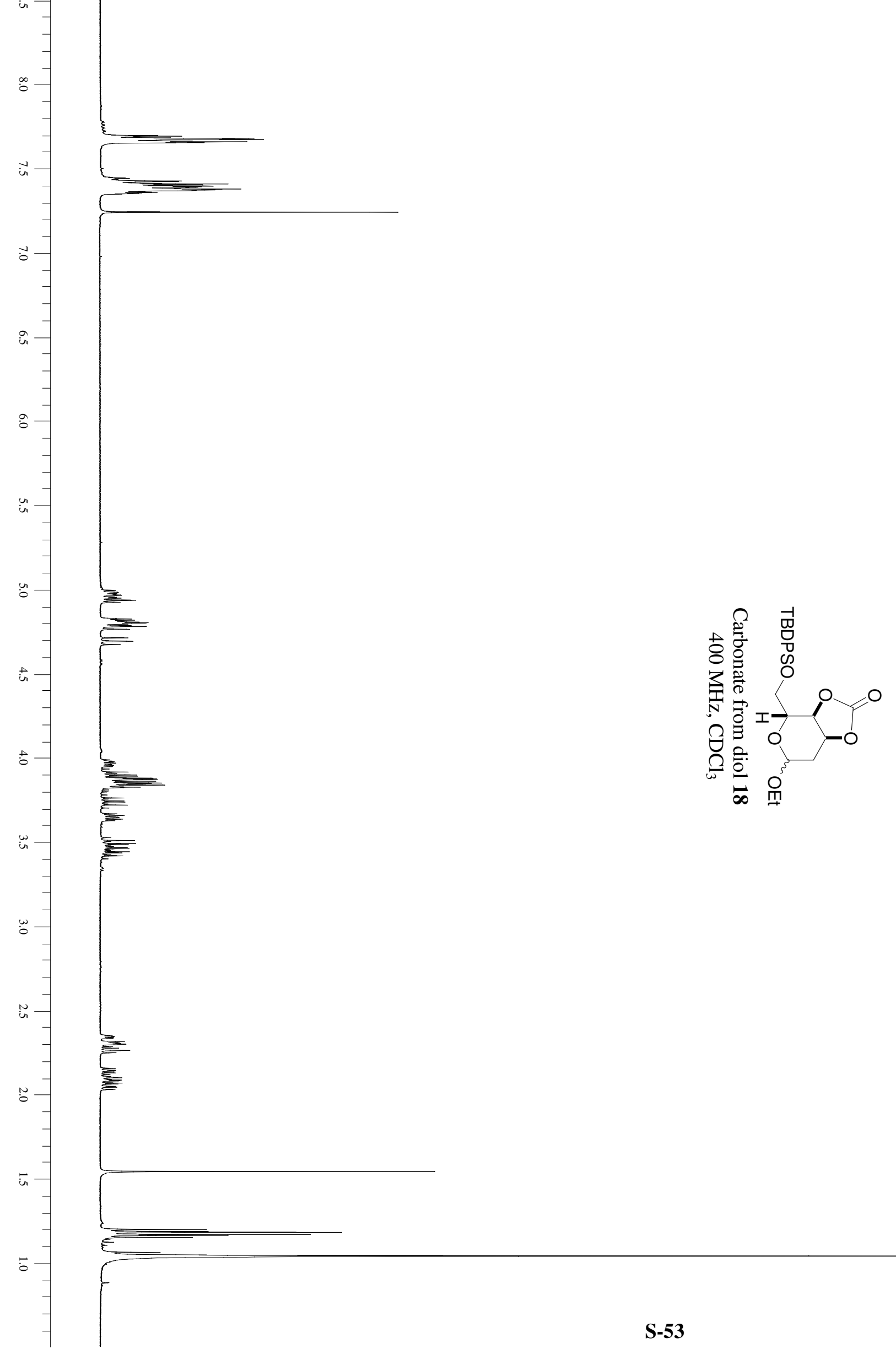




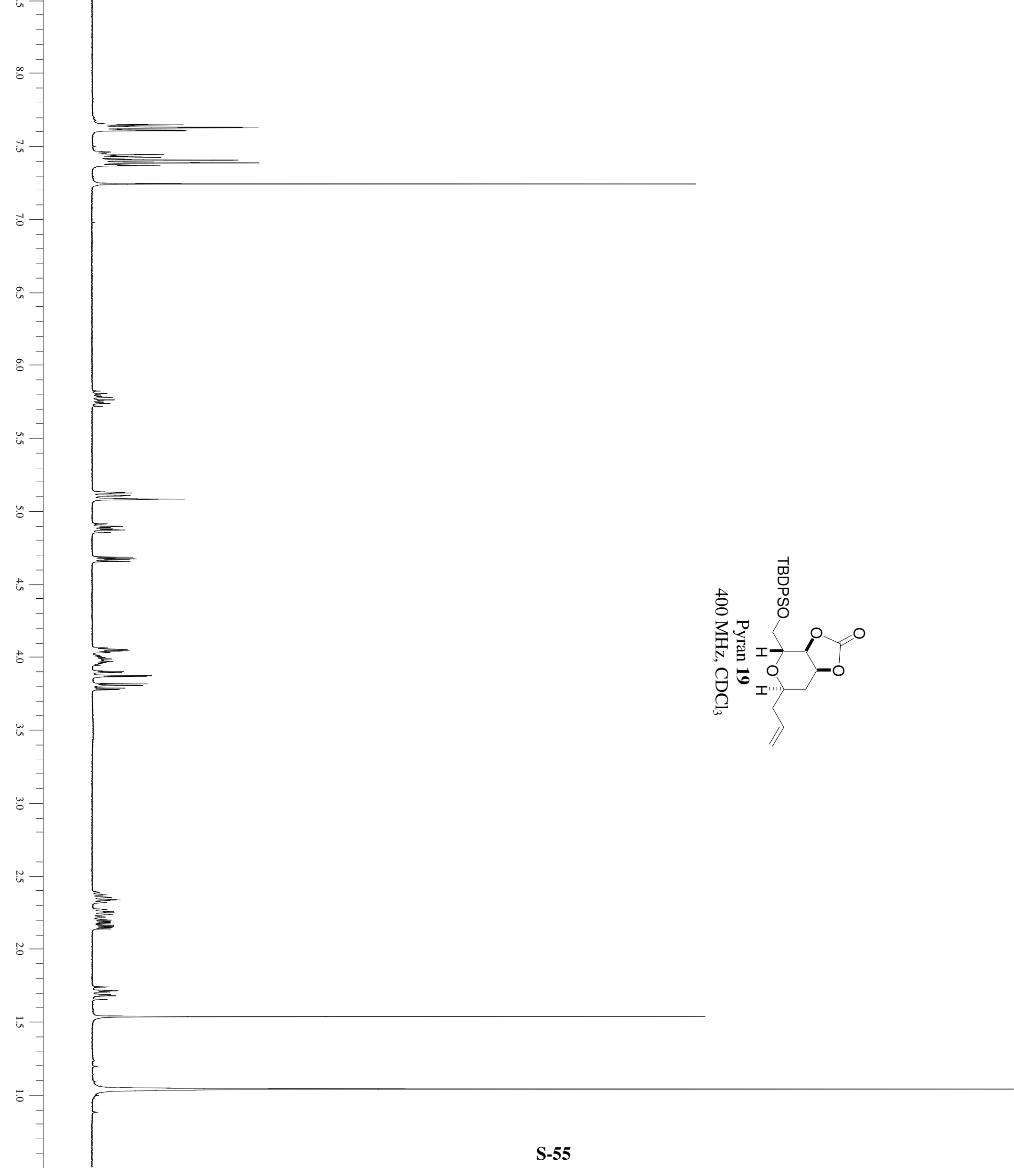




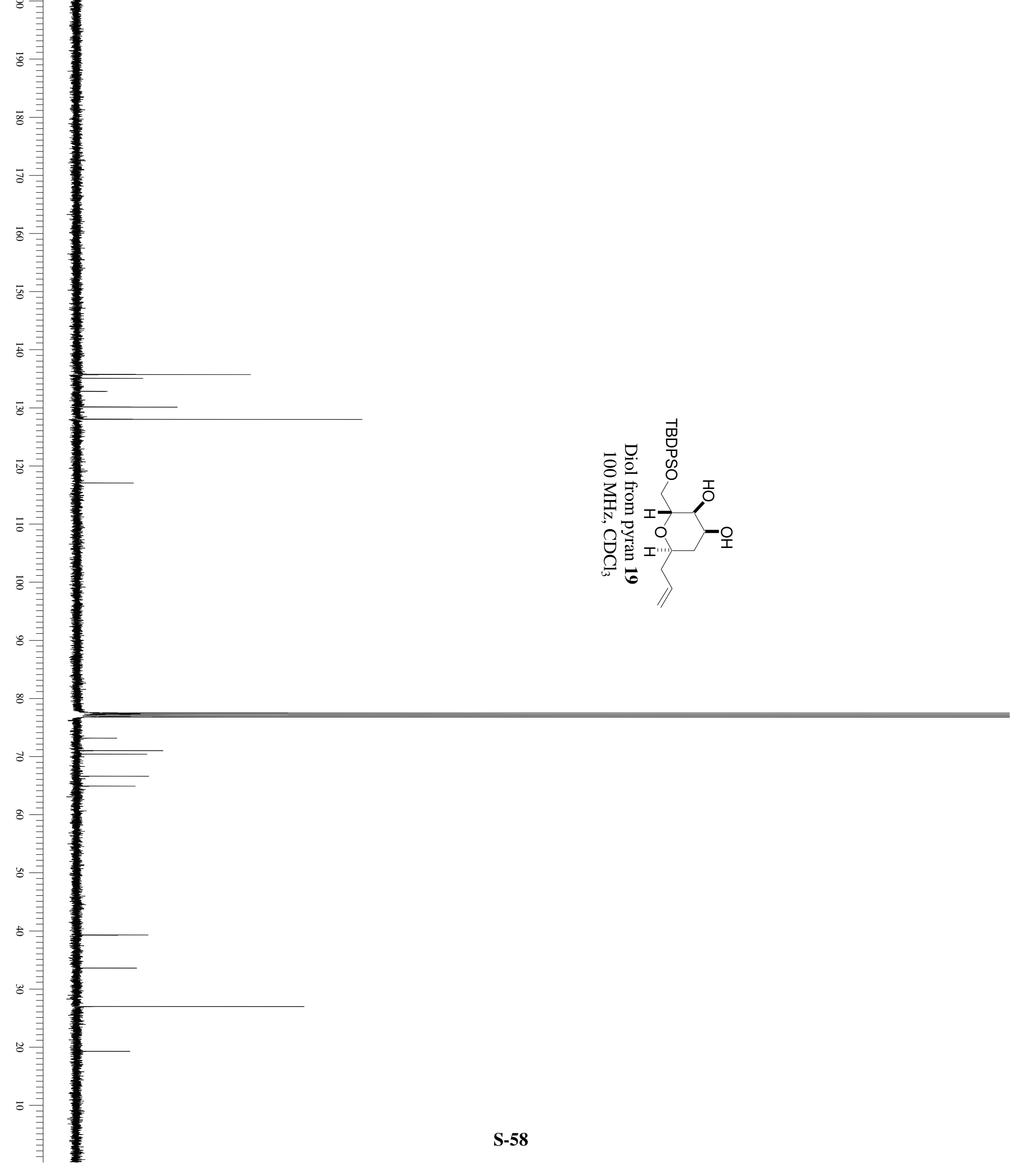




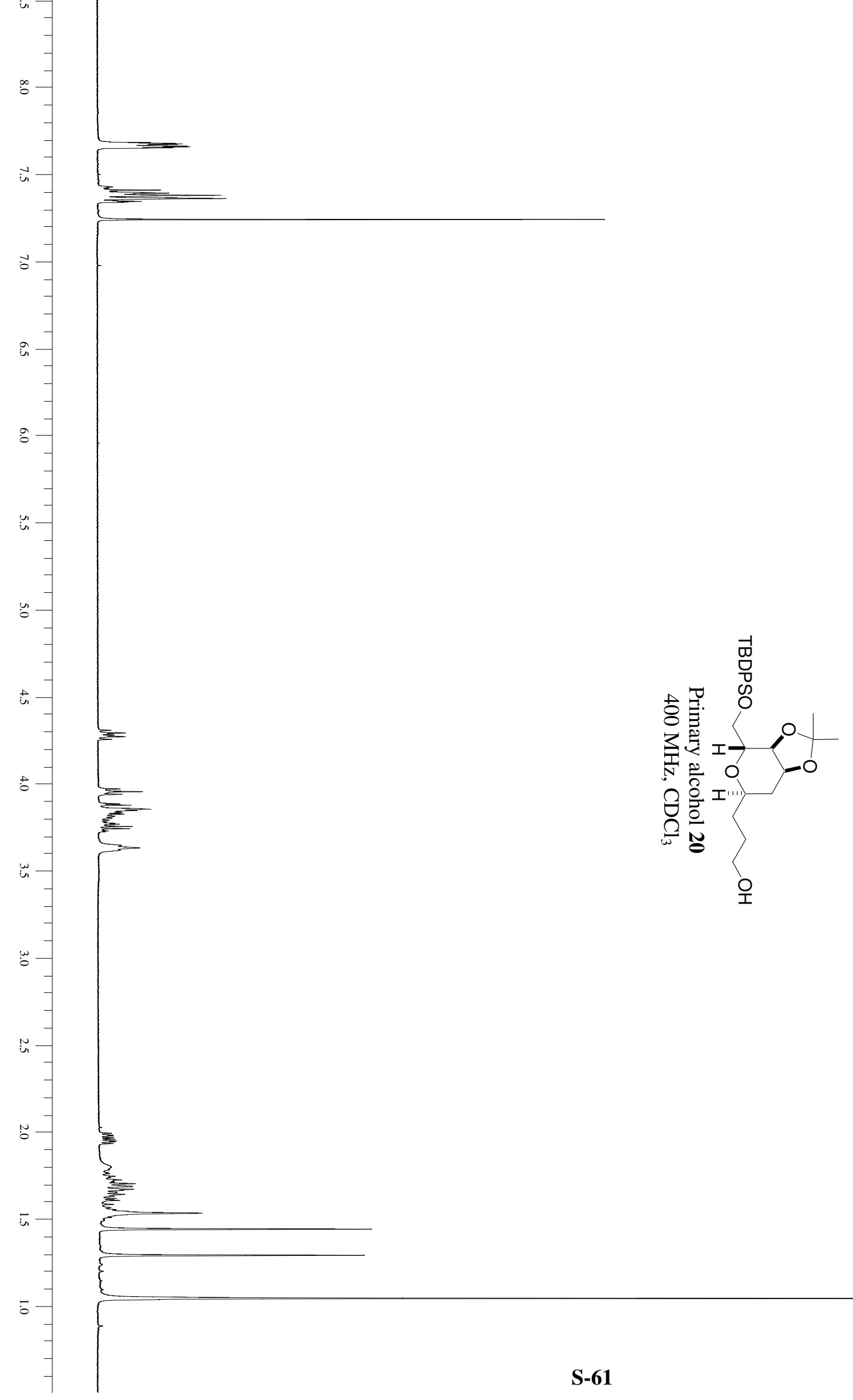




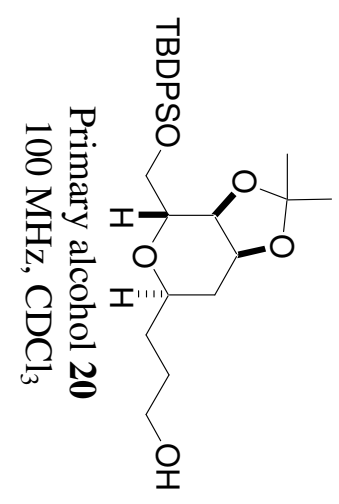




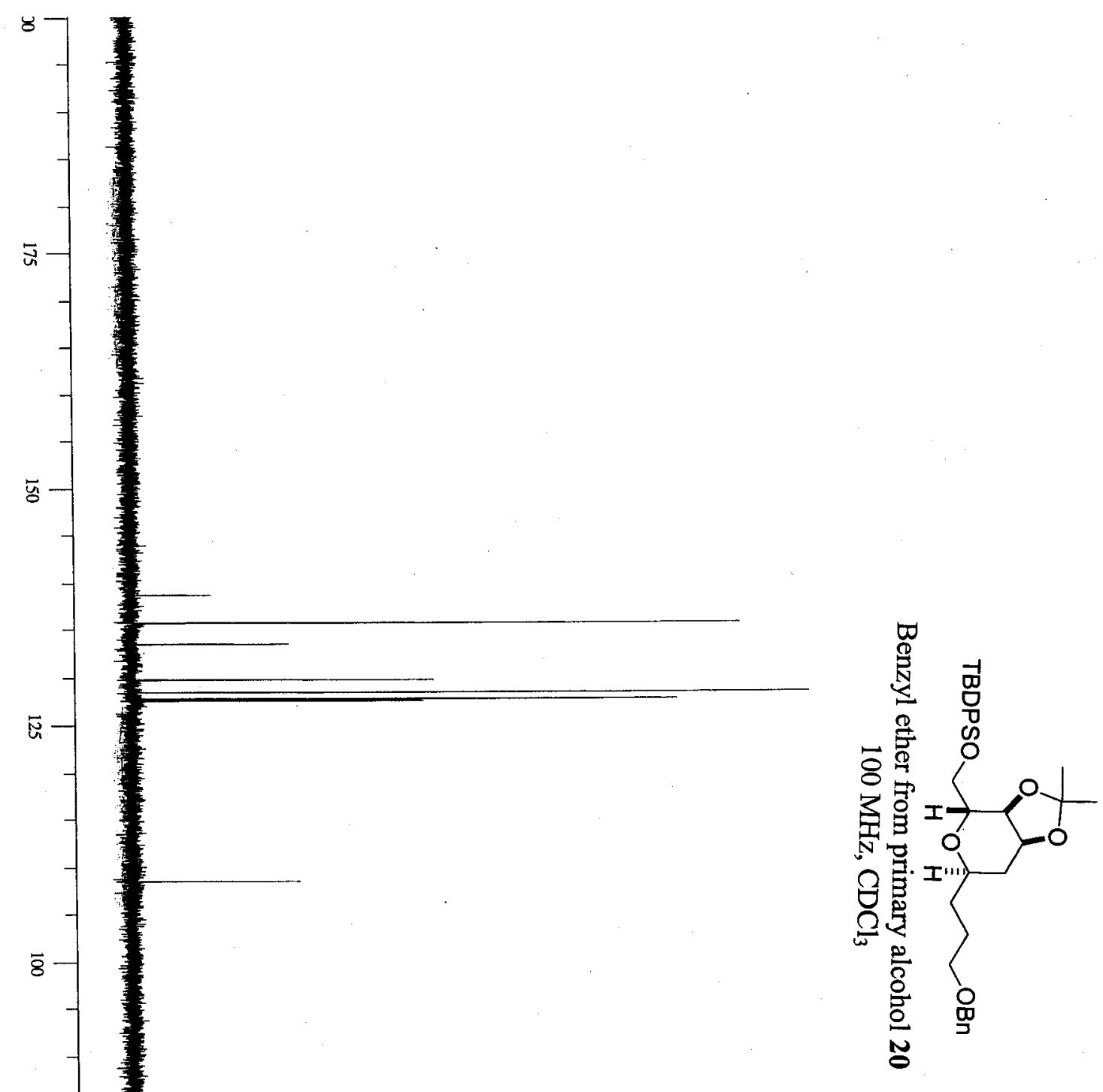




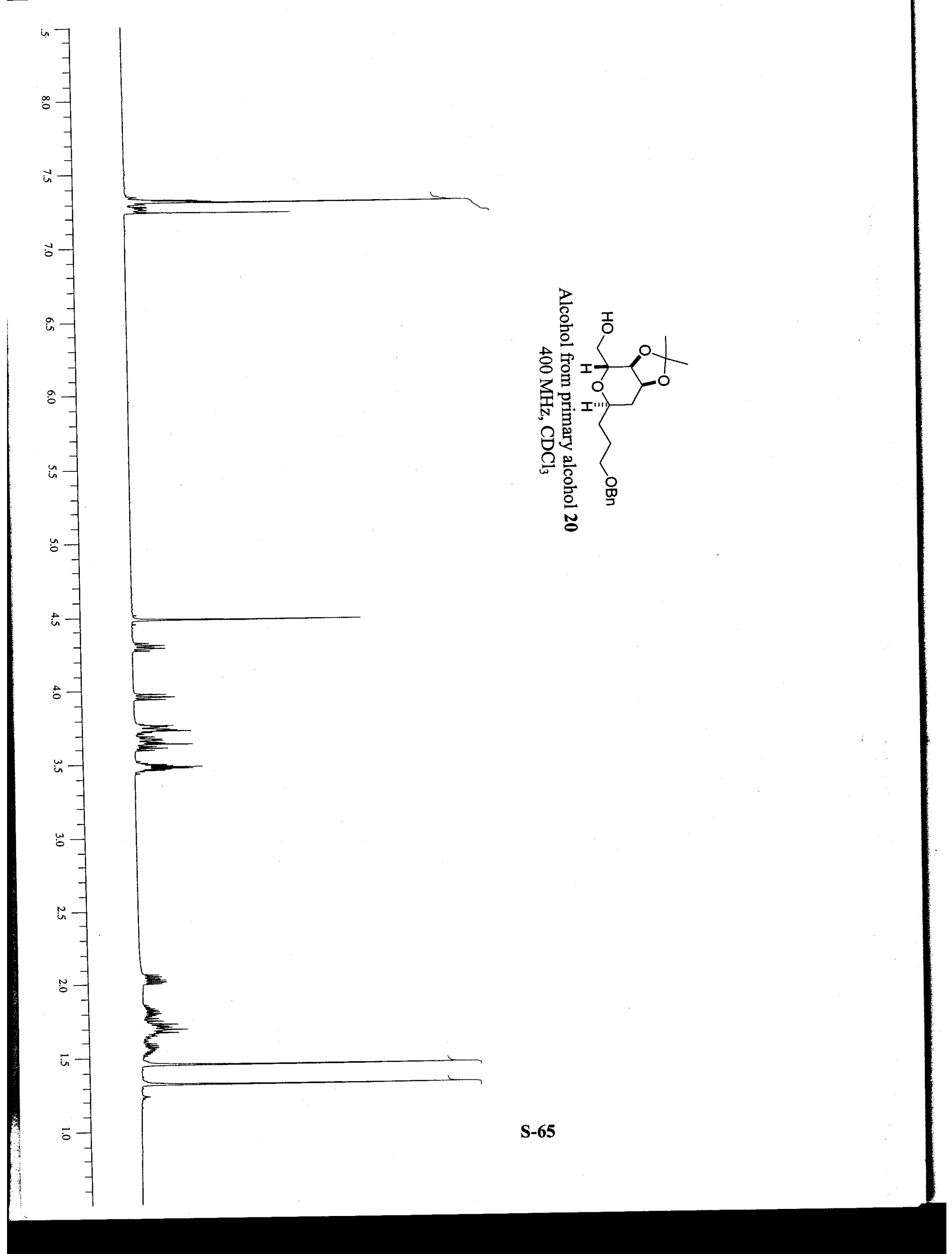




$$
E
$$




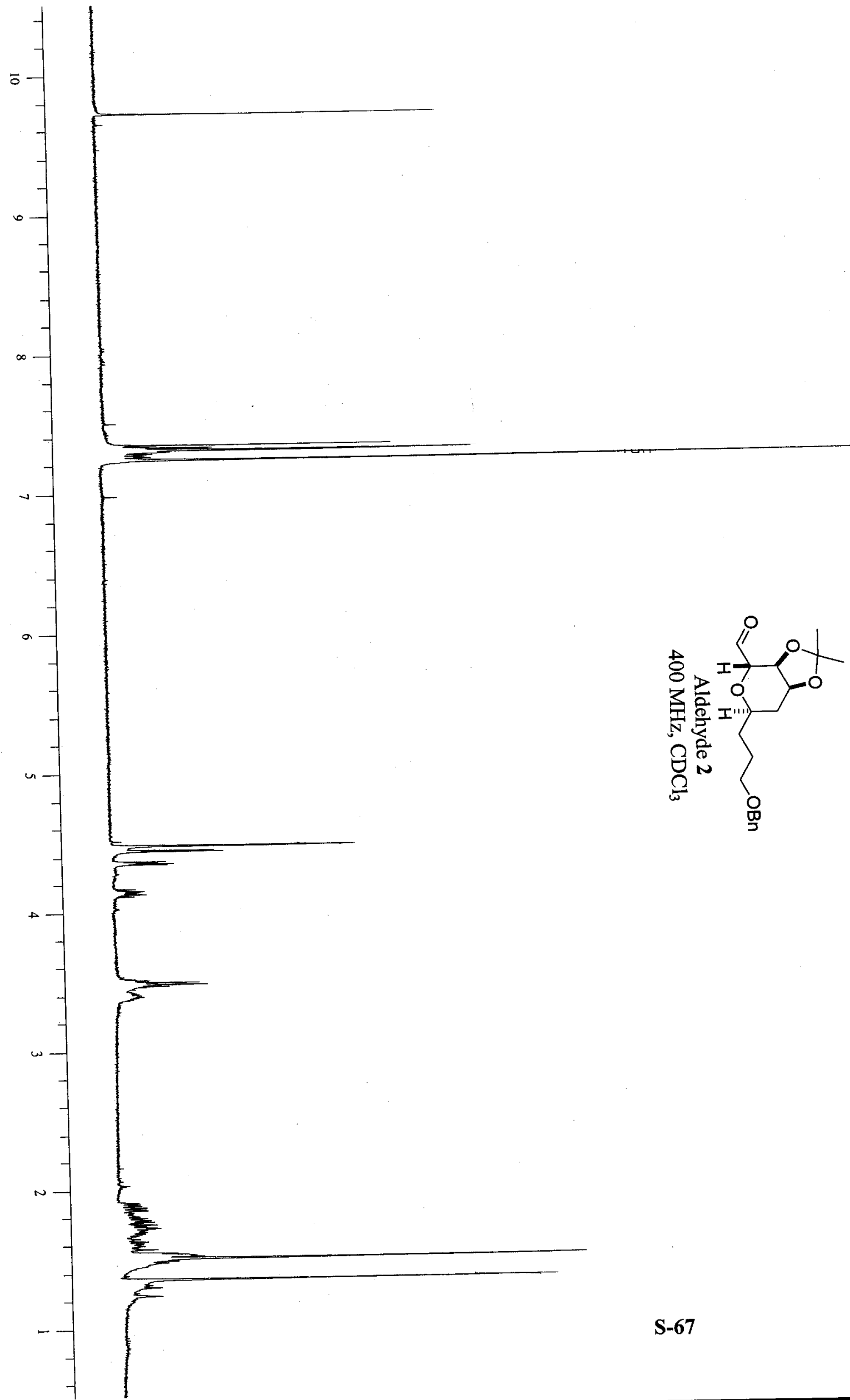




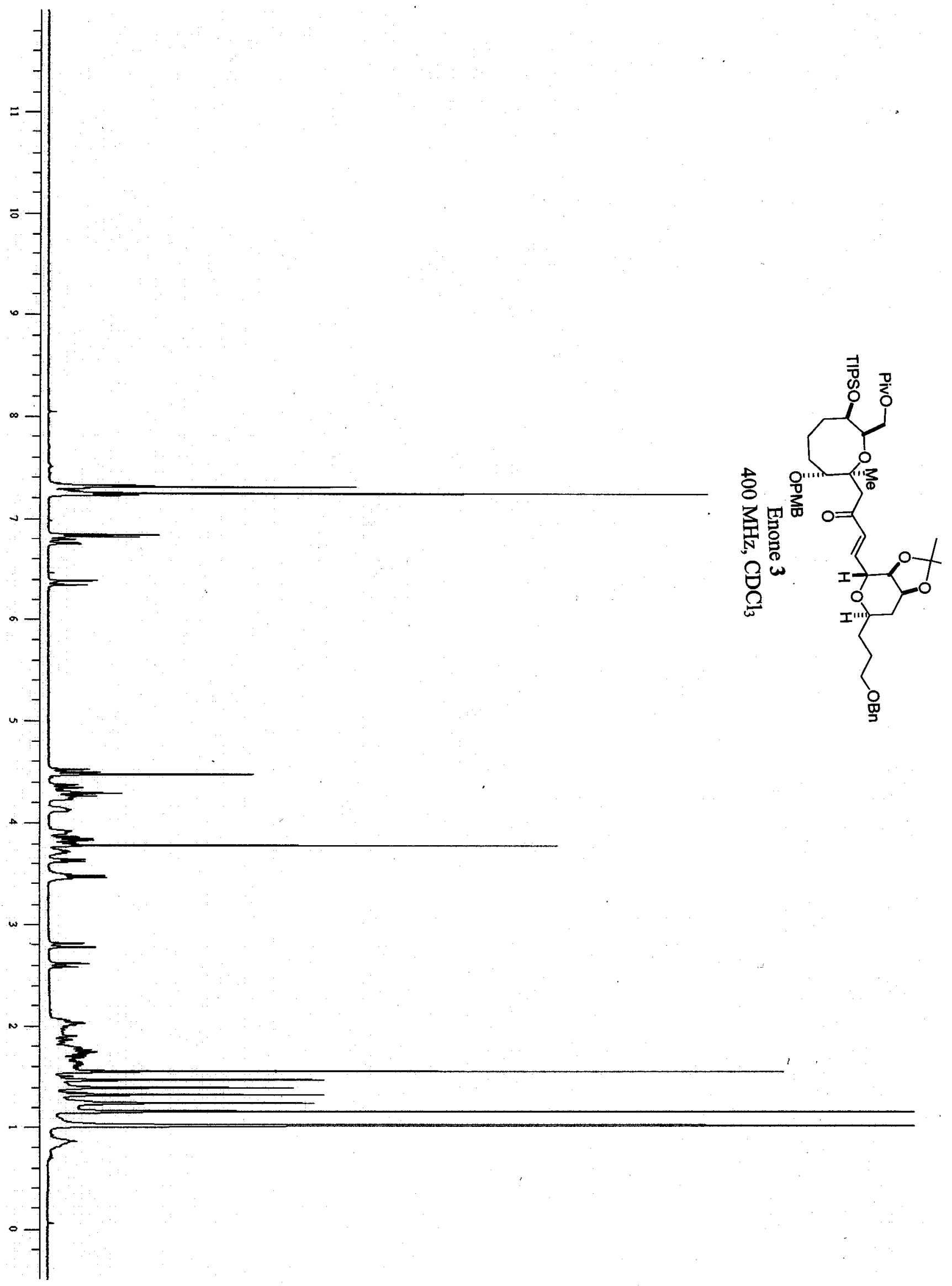




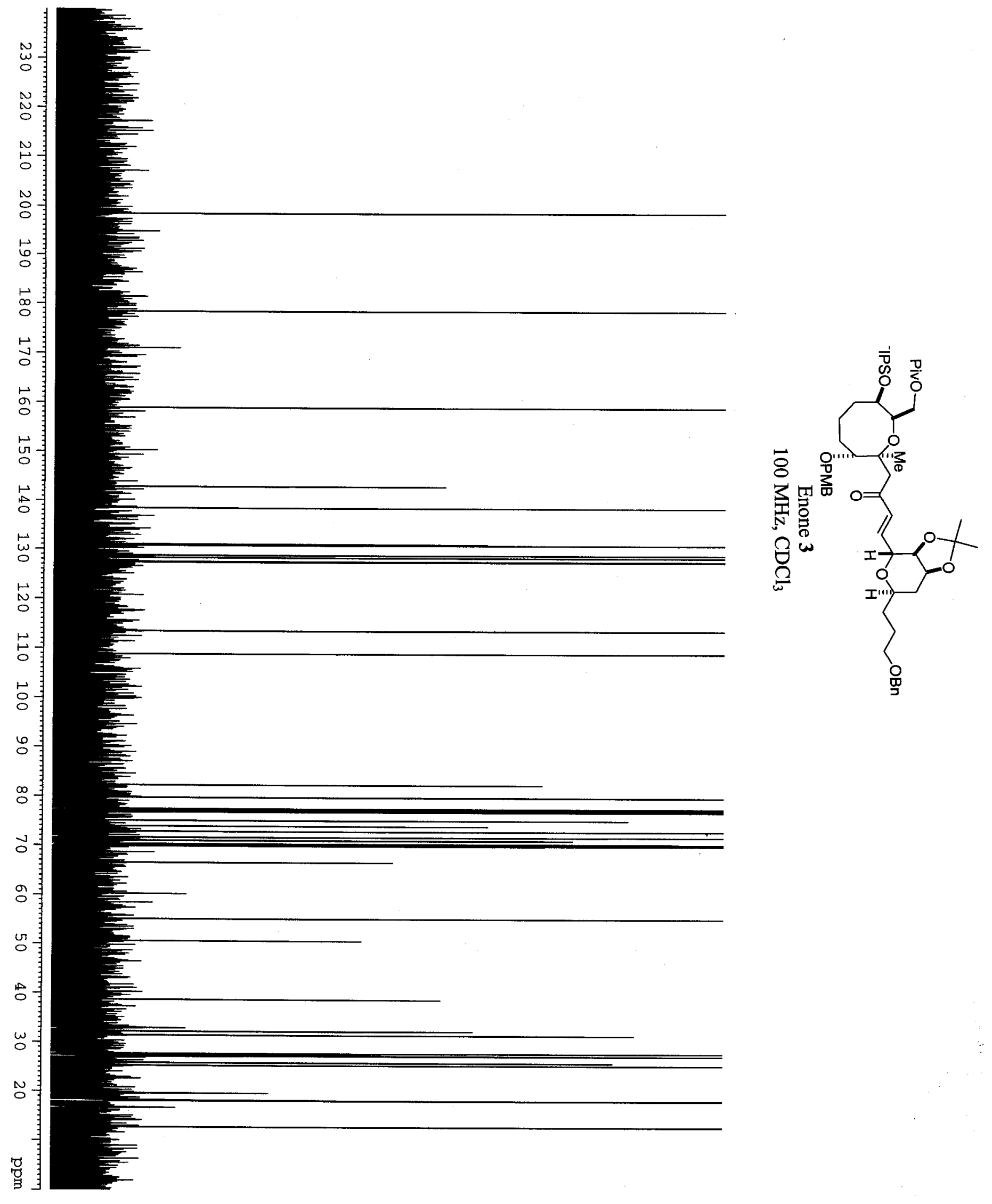




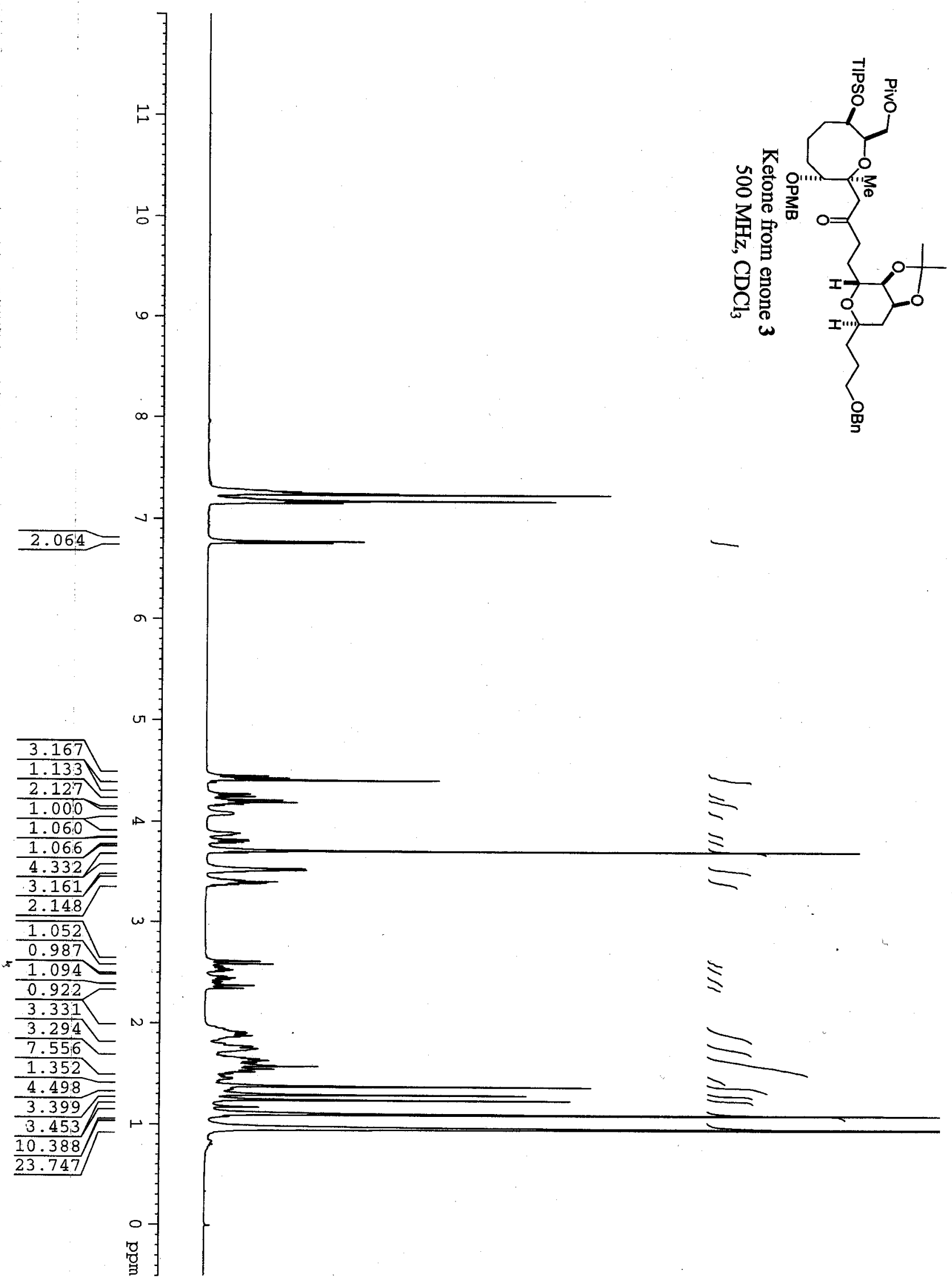




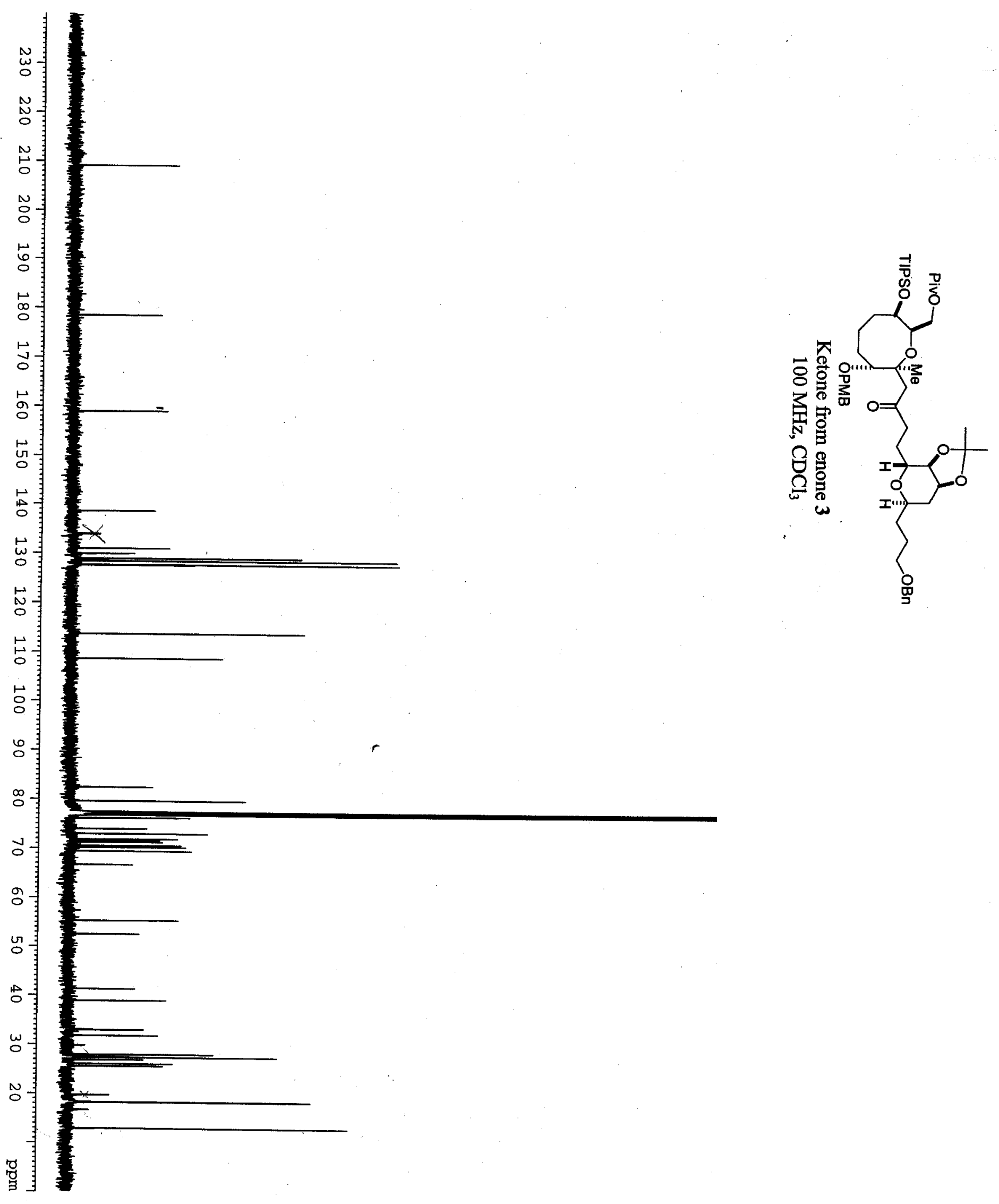




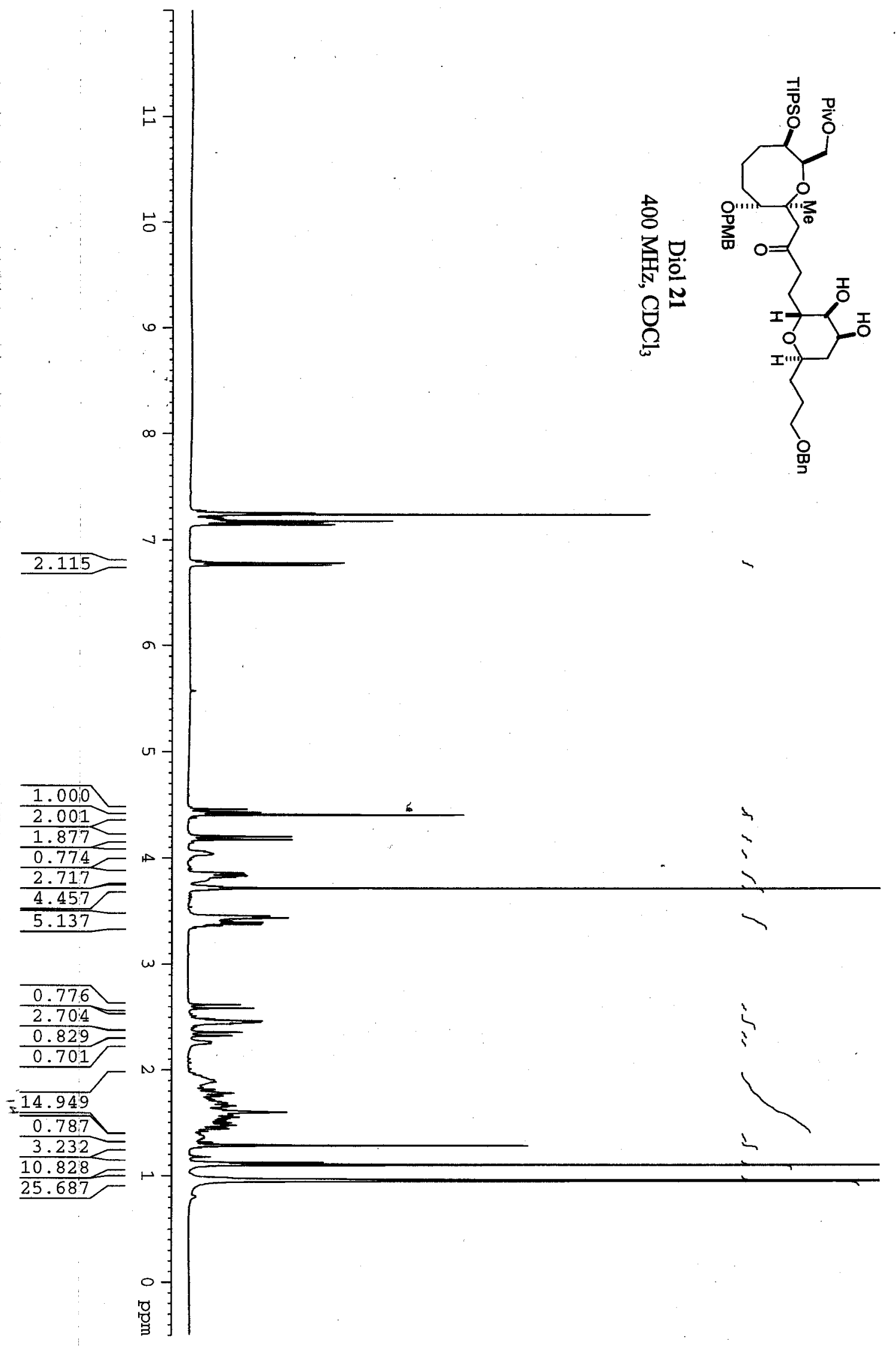




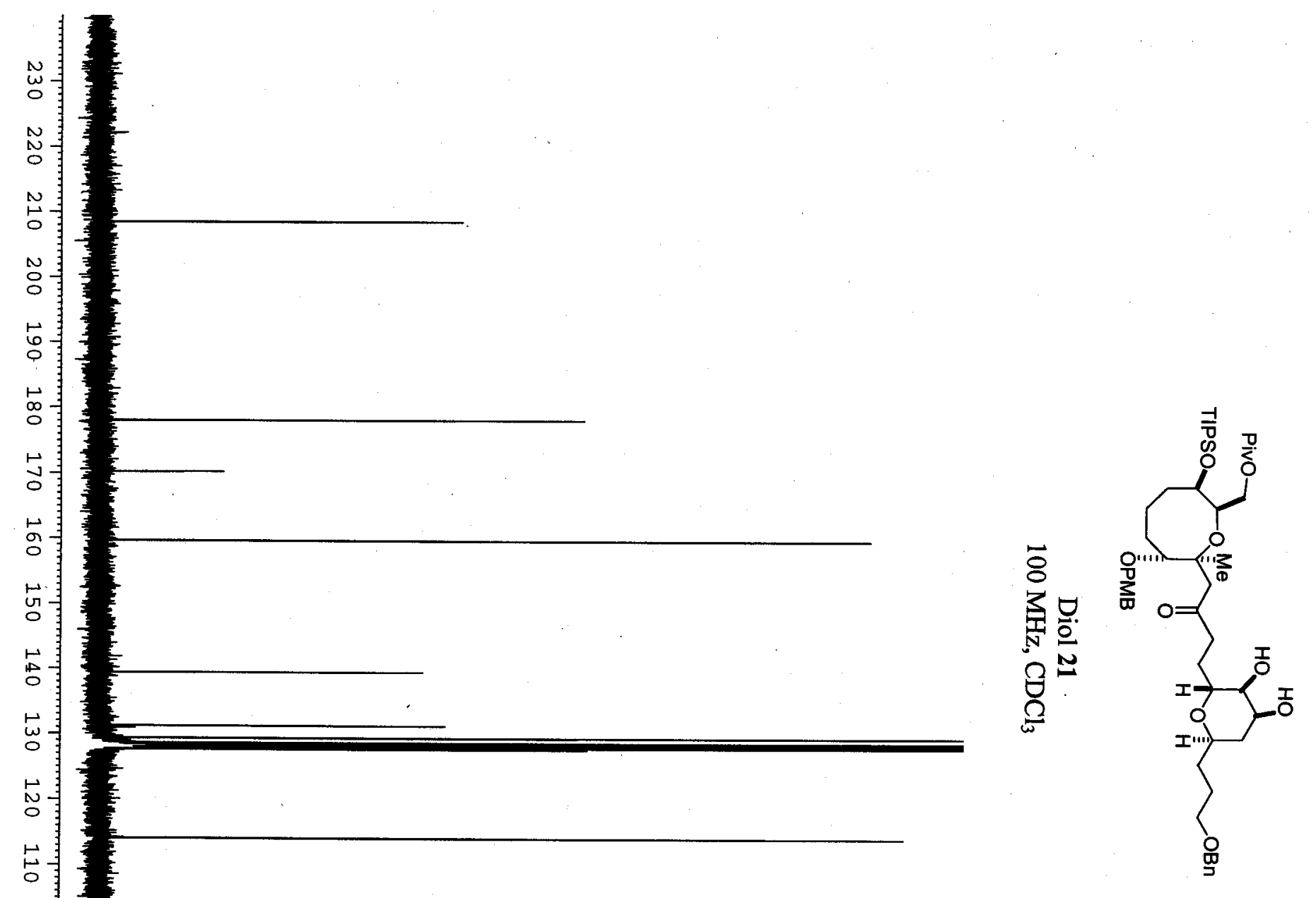




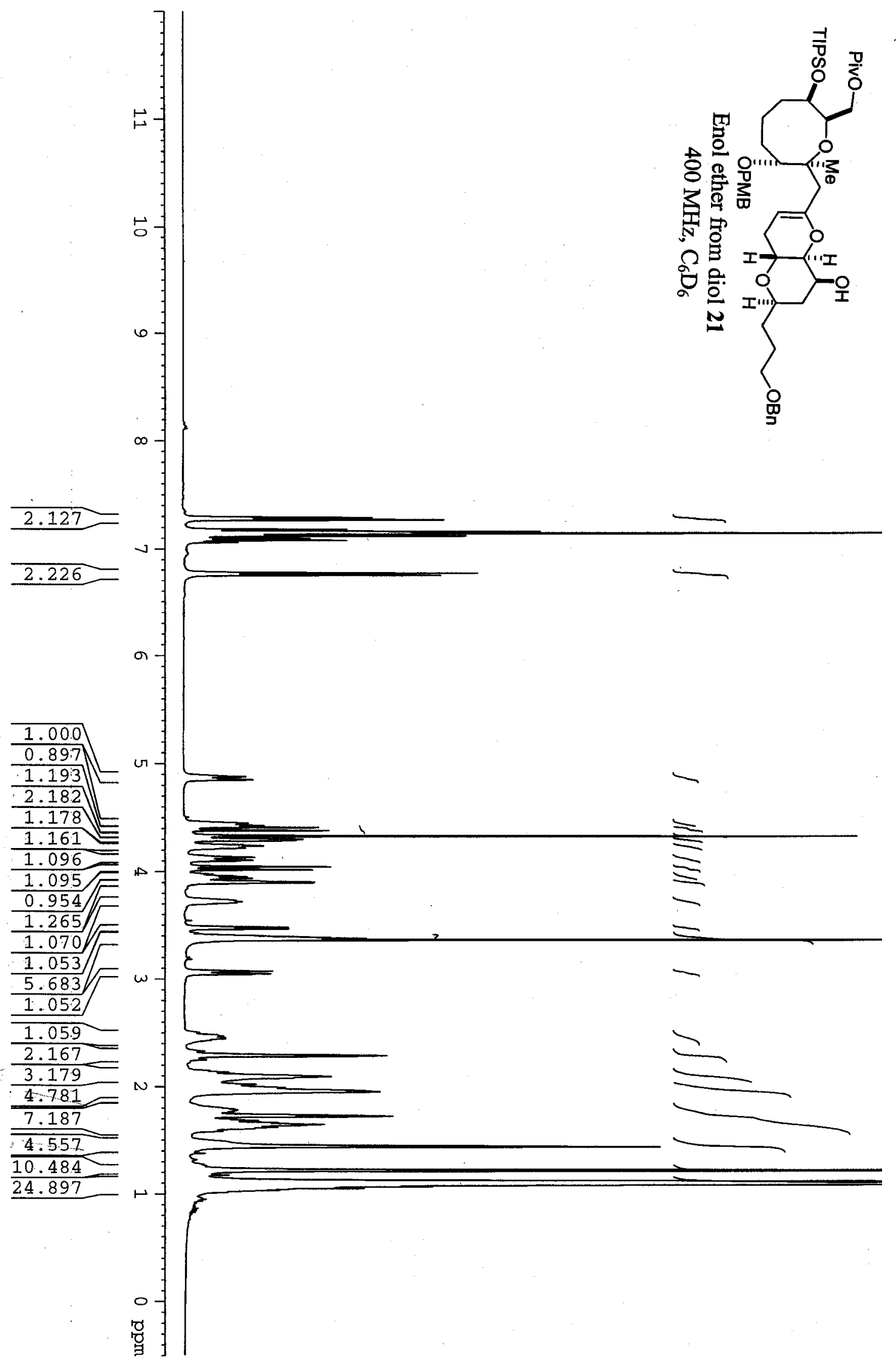




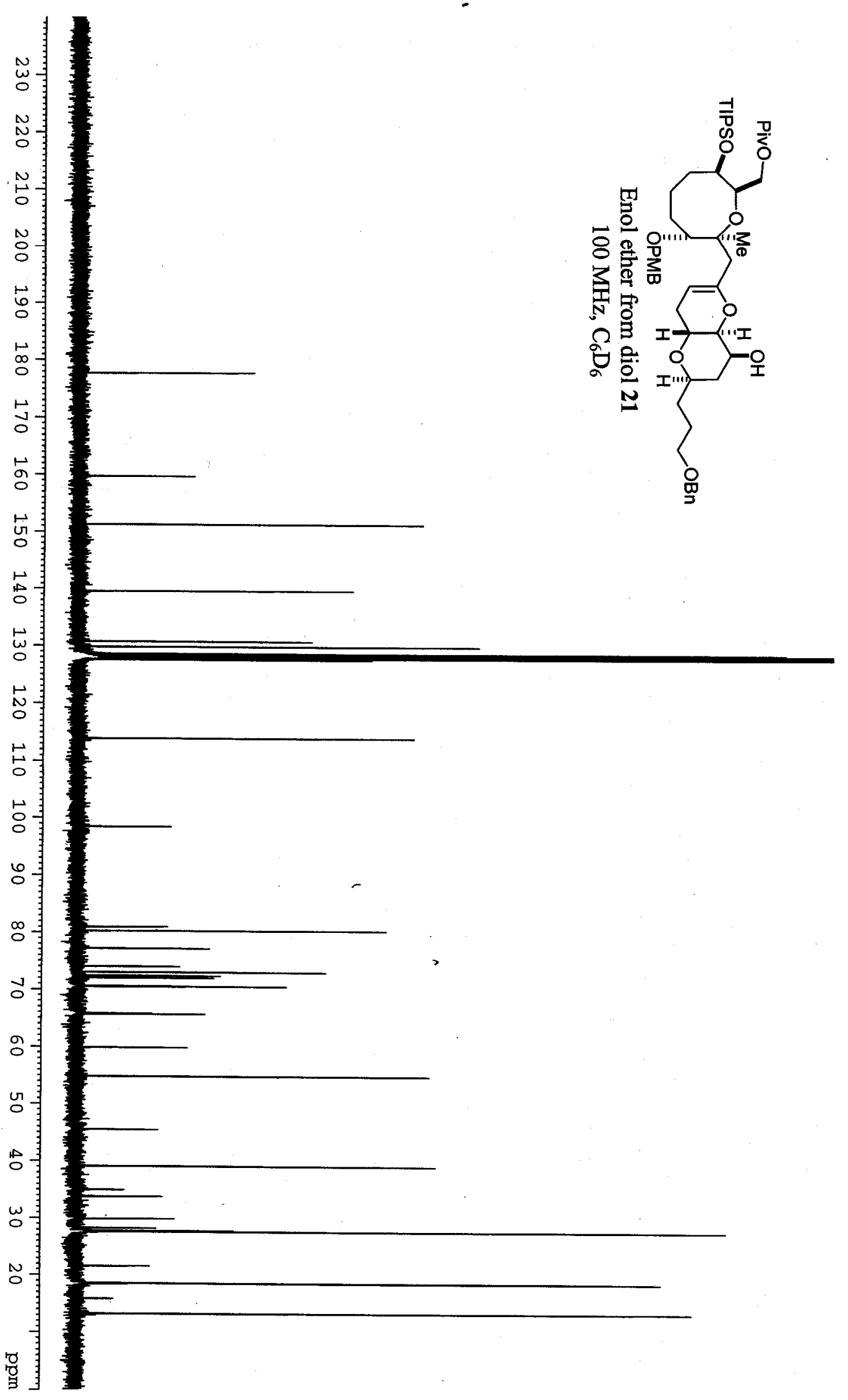




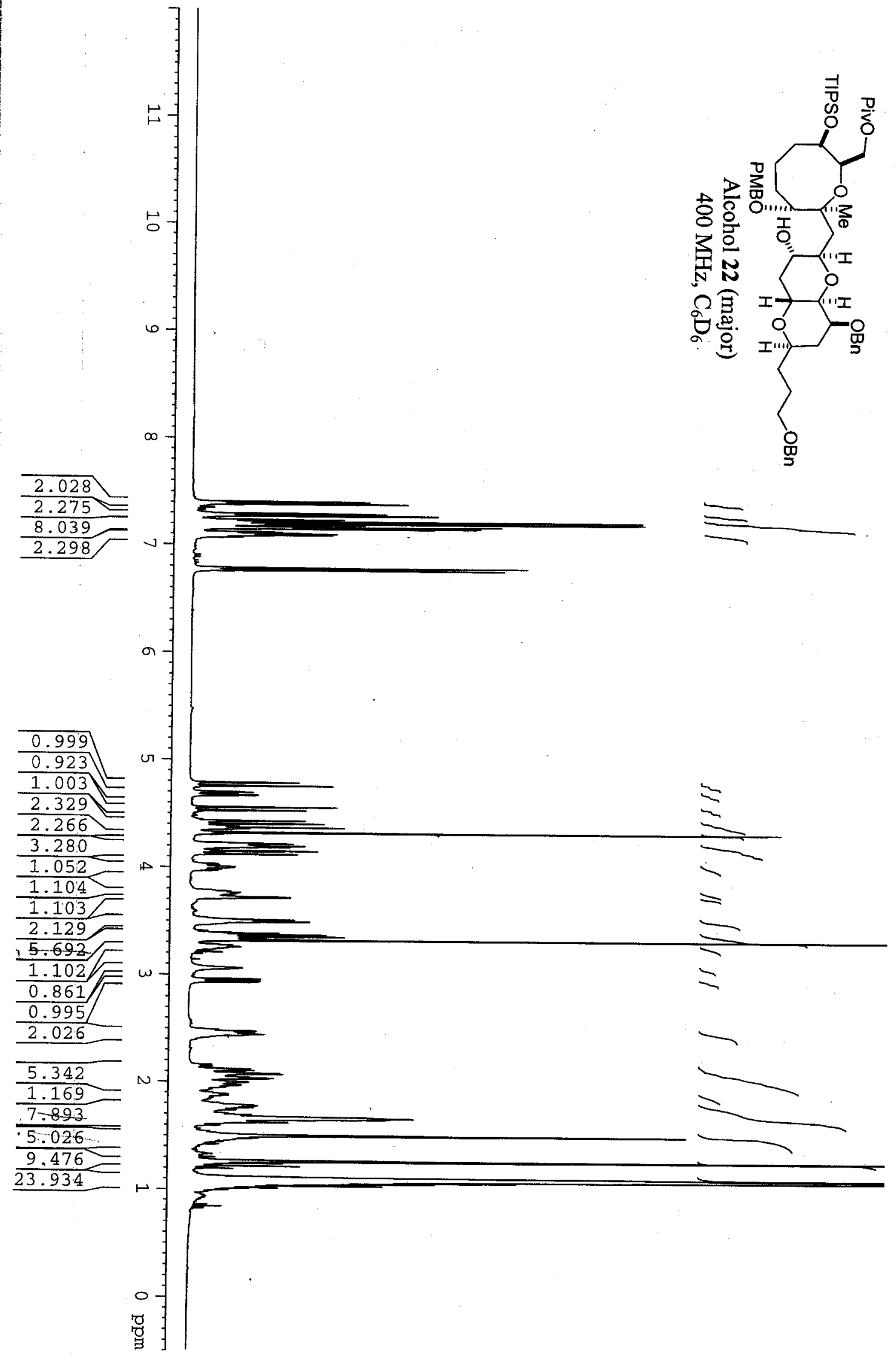




$$
k^{\prime \prime}
$$




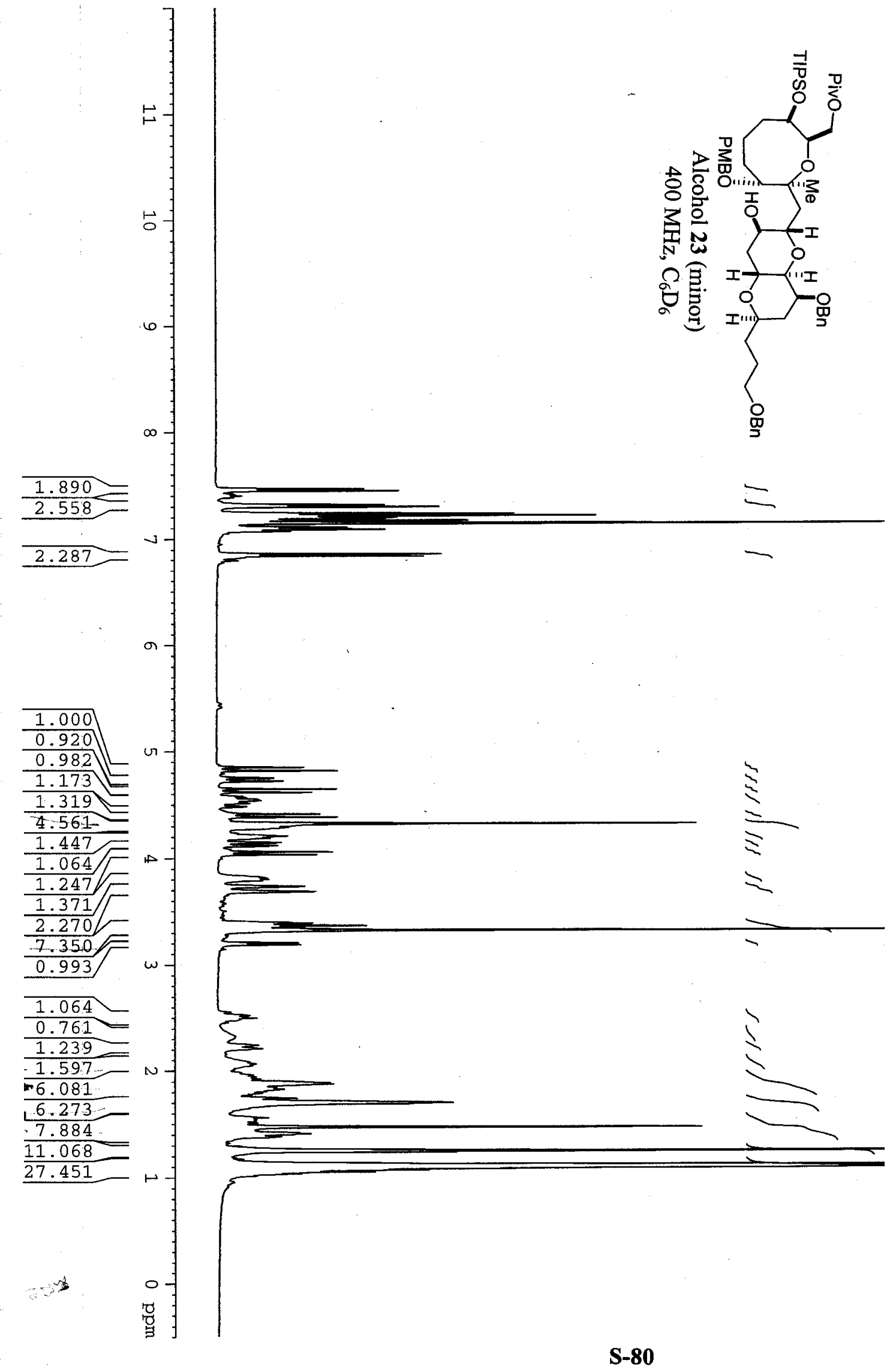




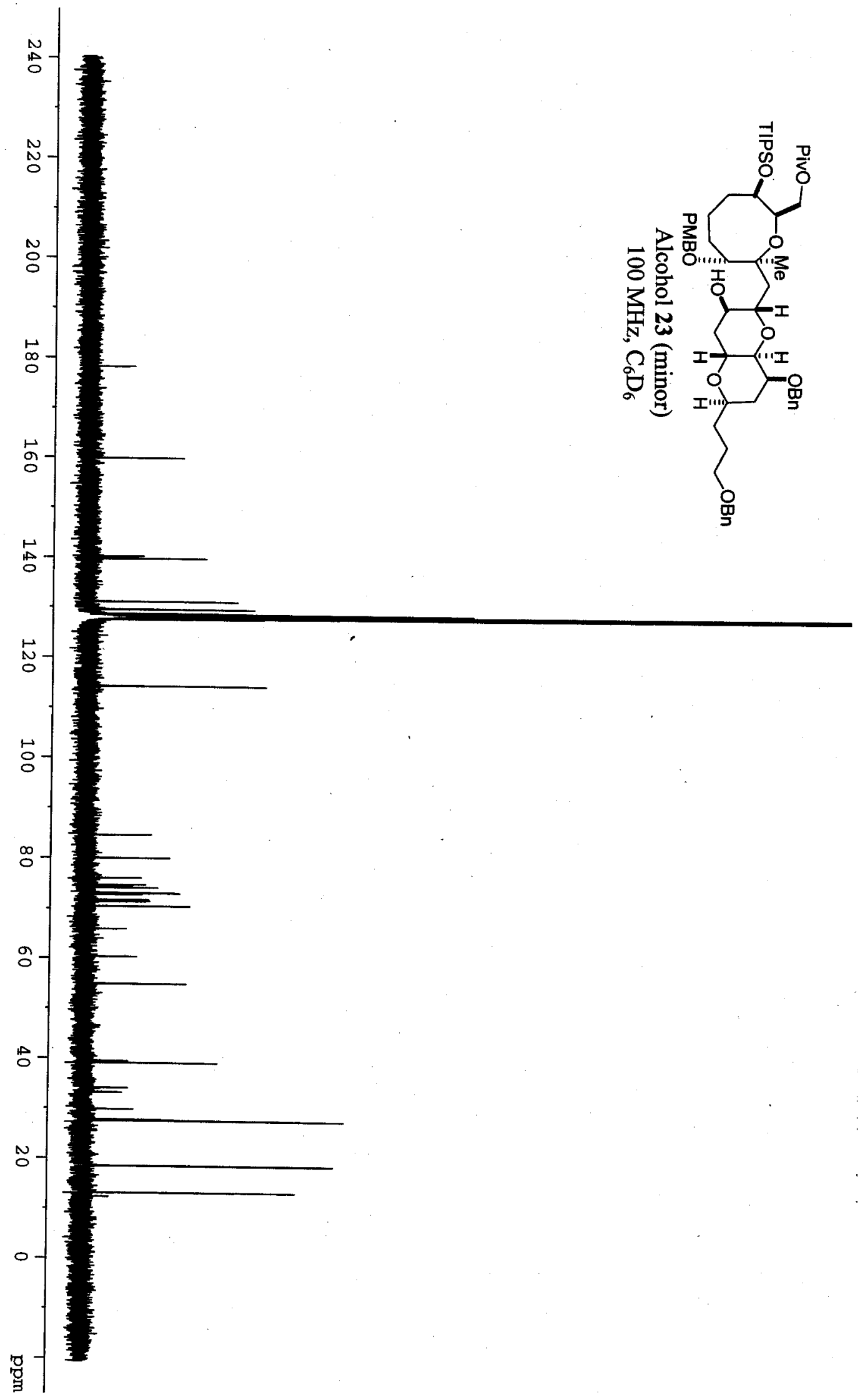



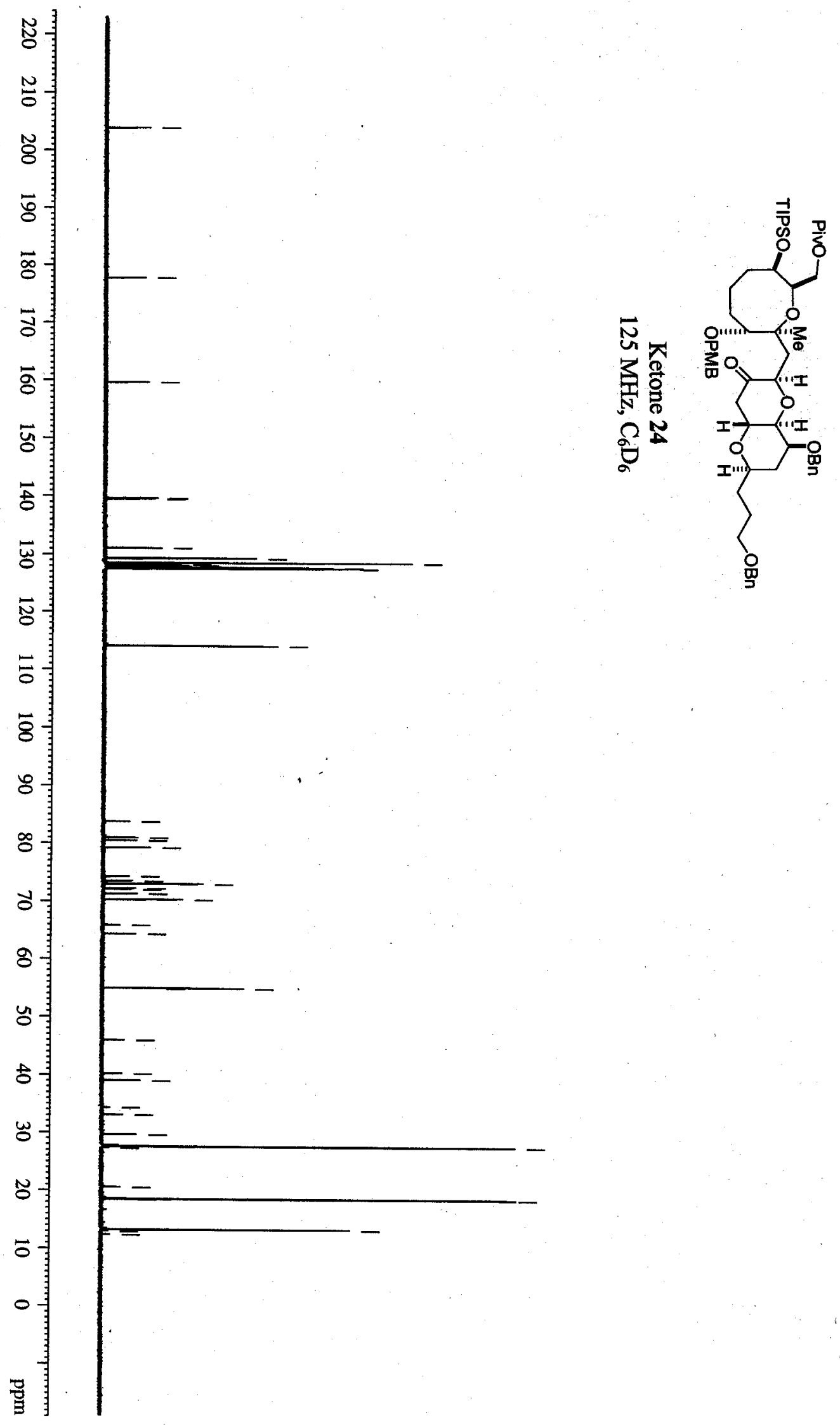


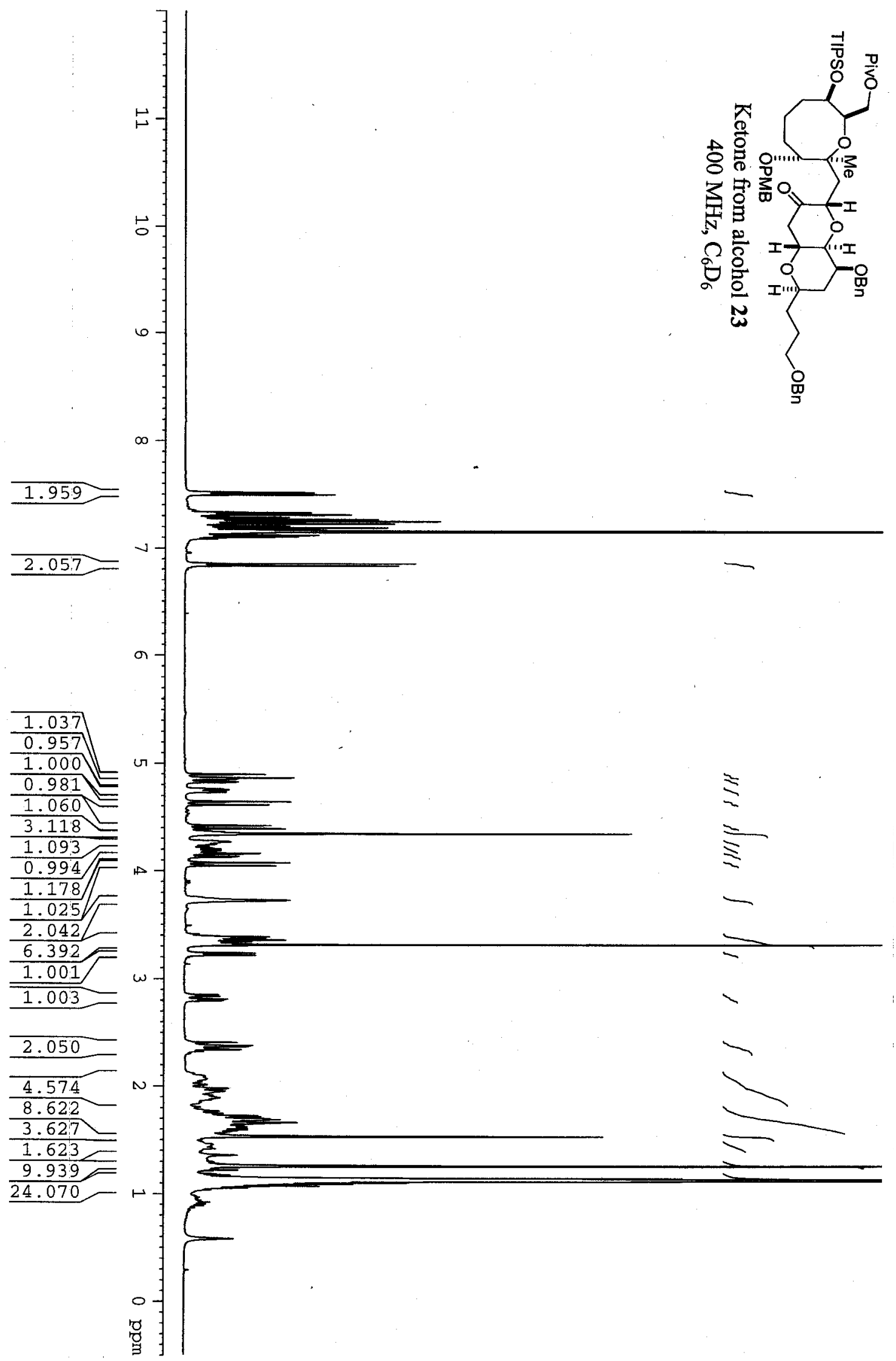




$$
\mid
$$




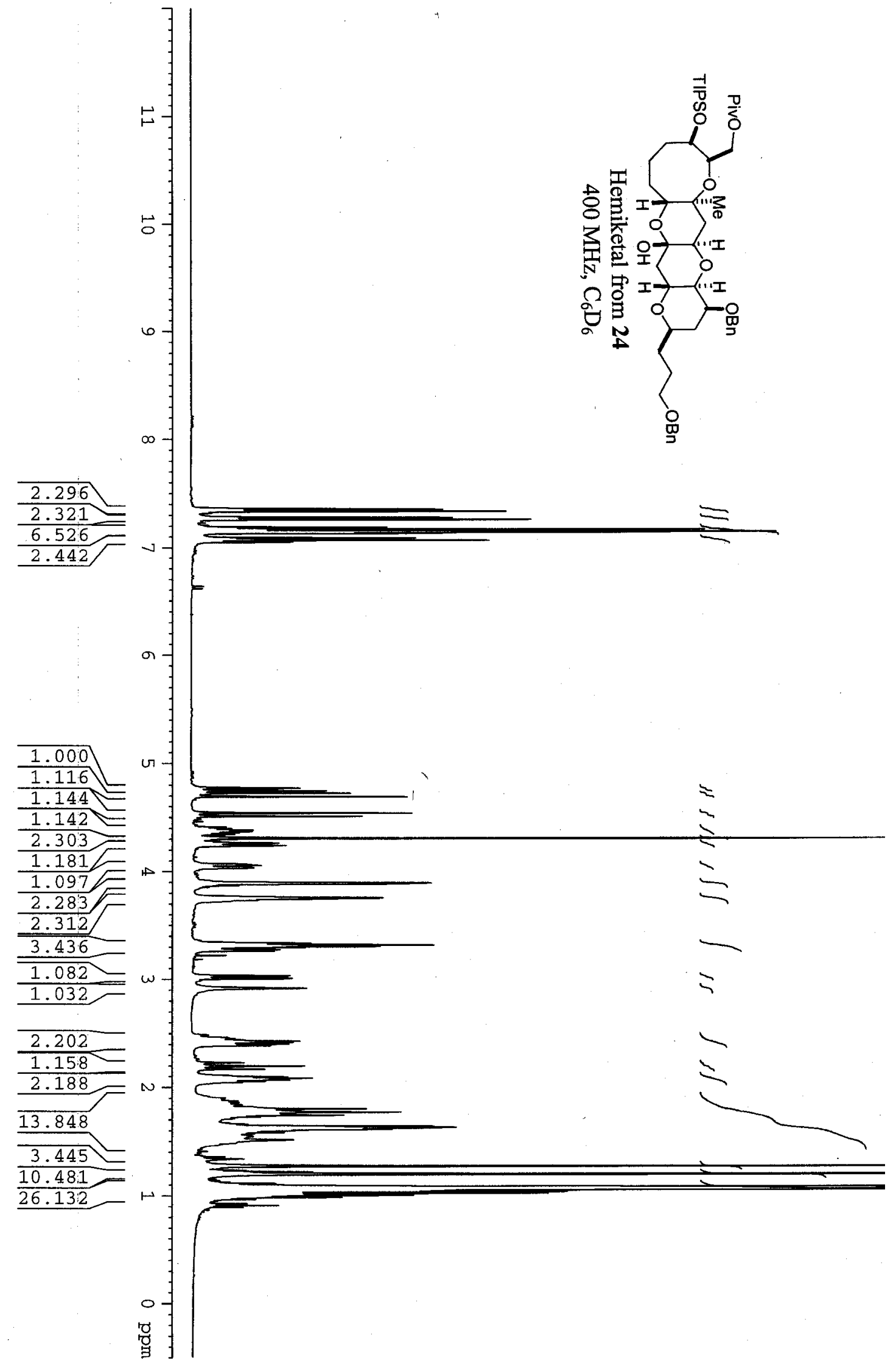



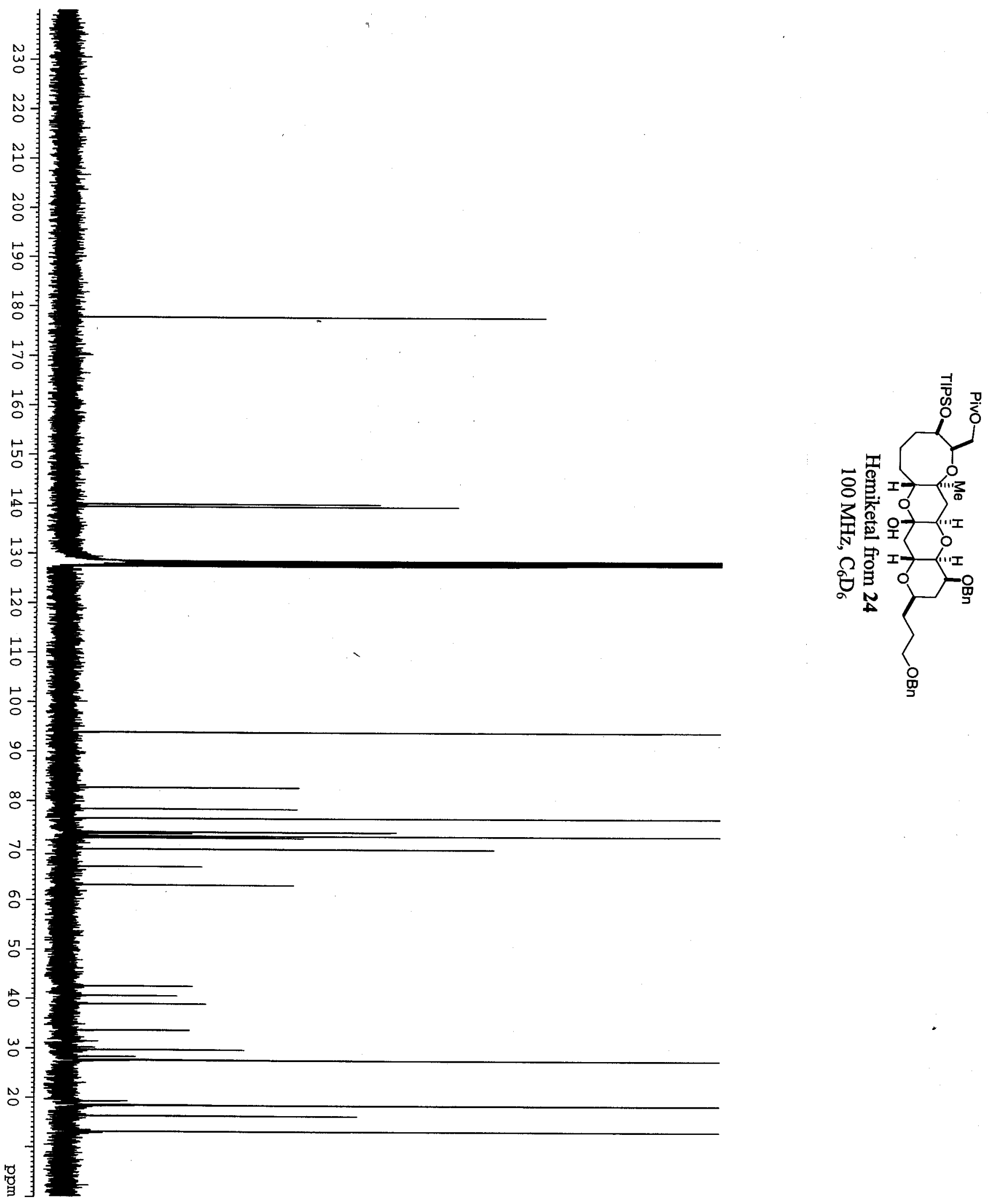

S-87 


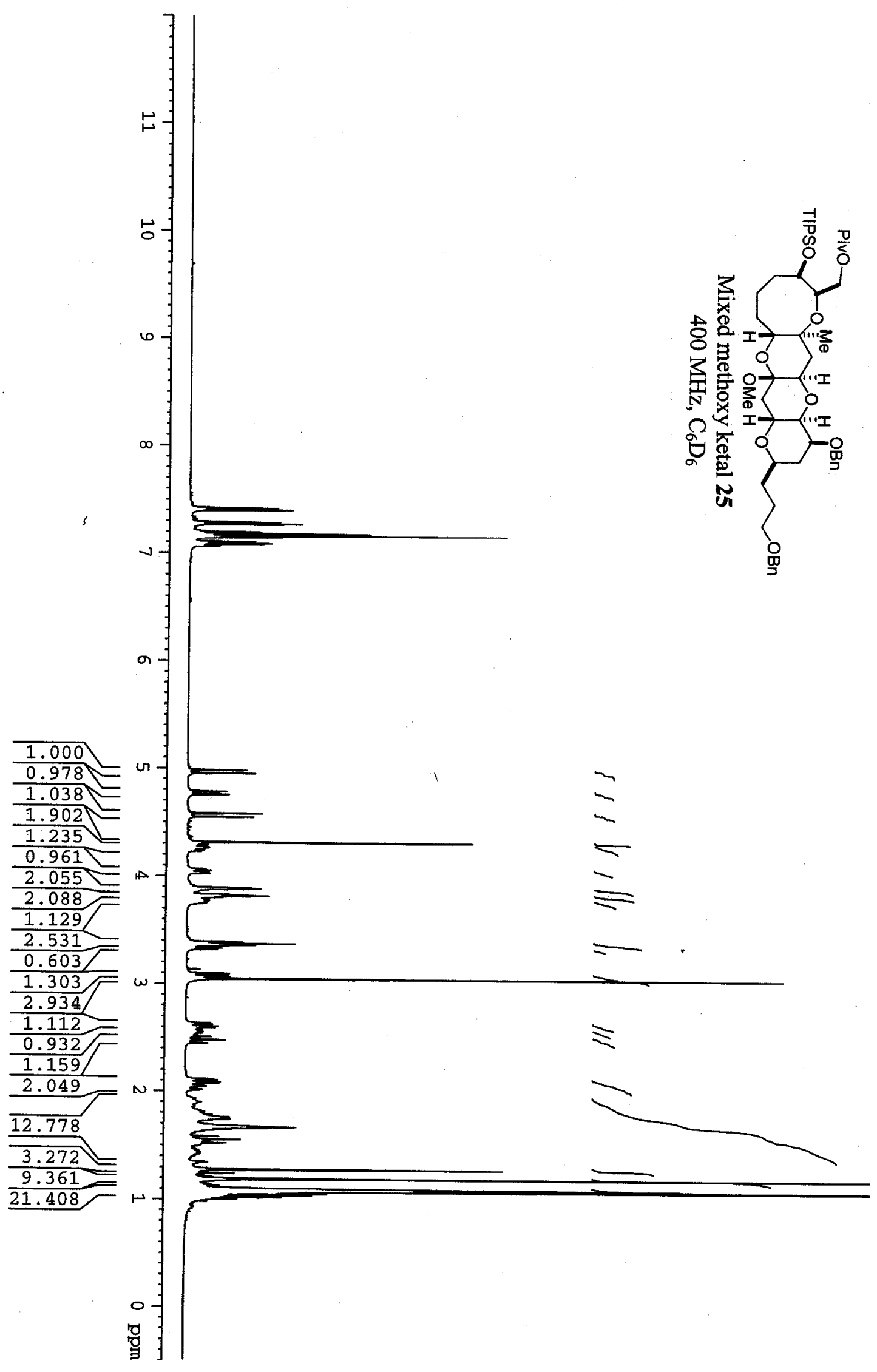



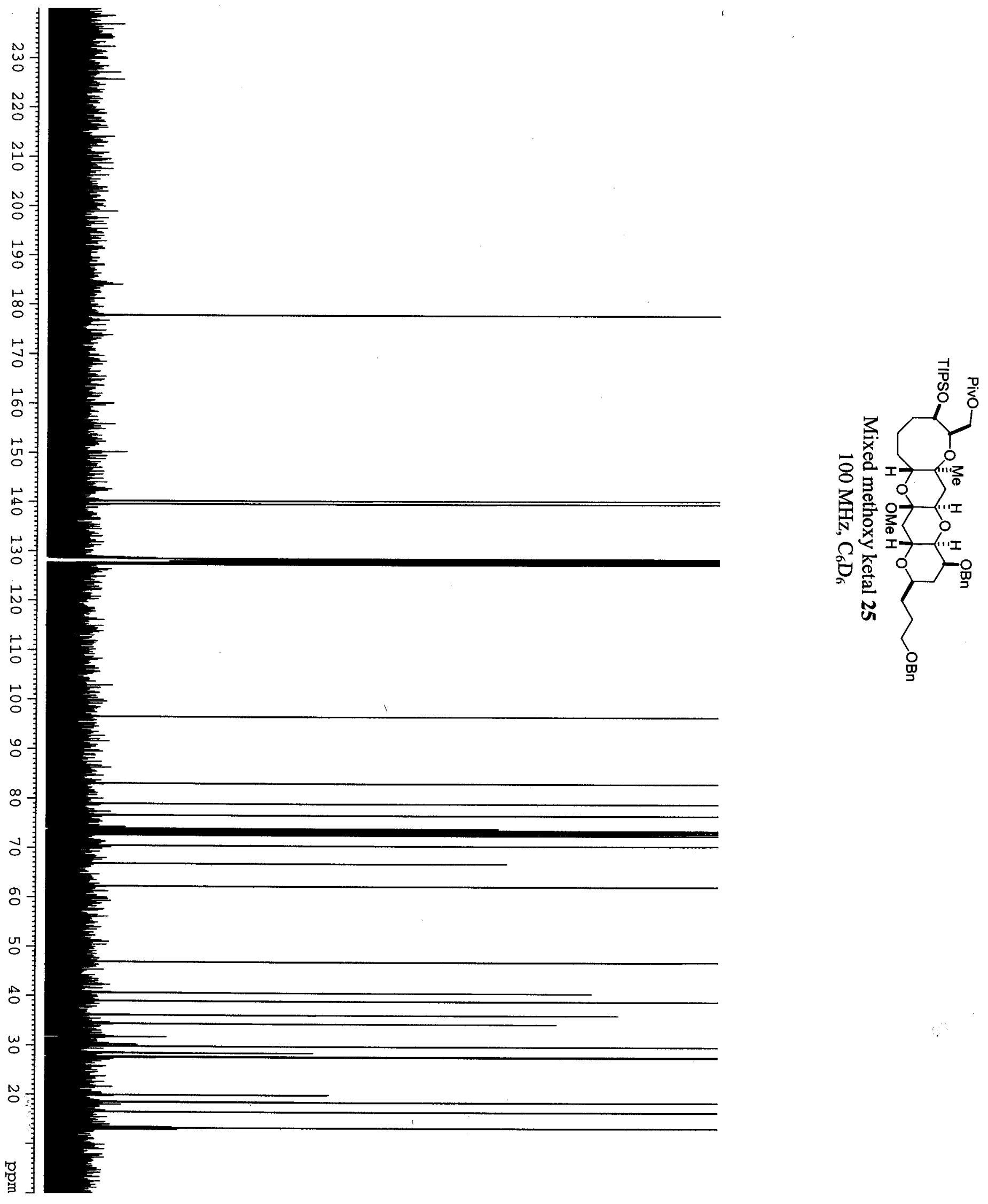


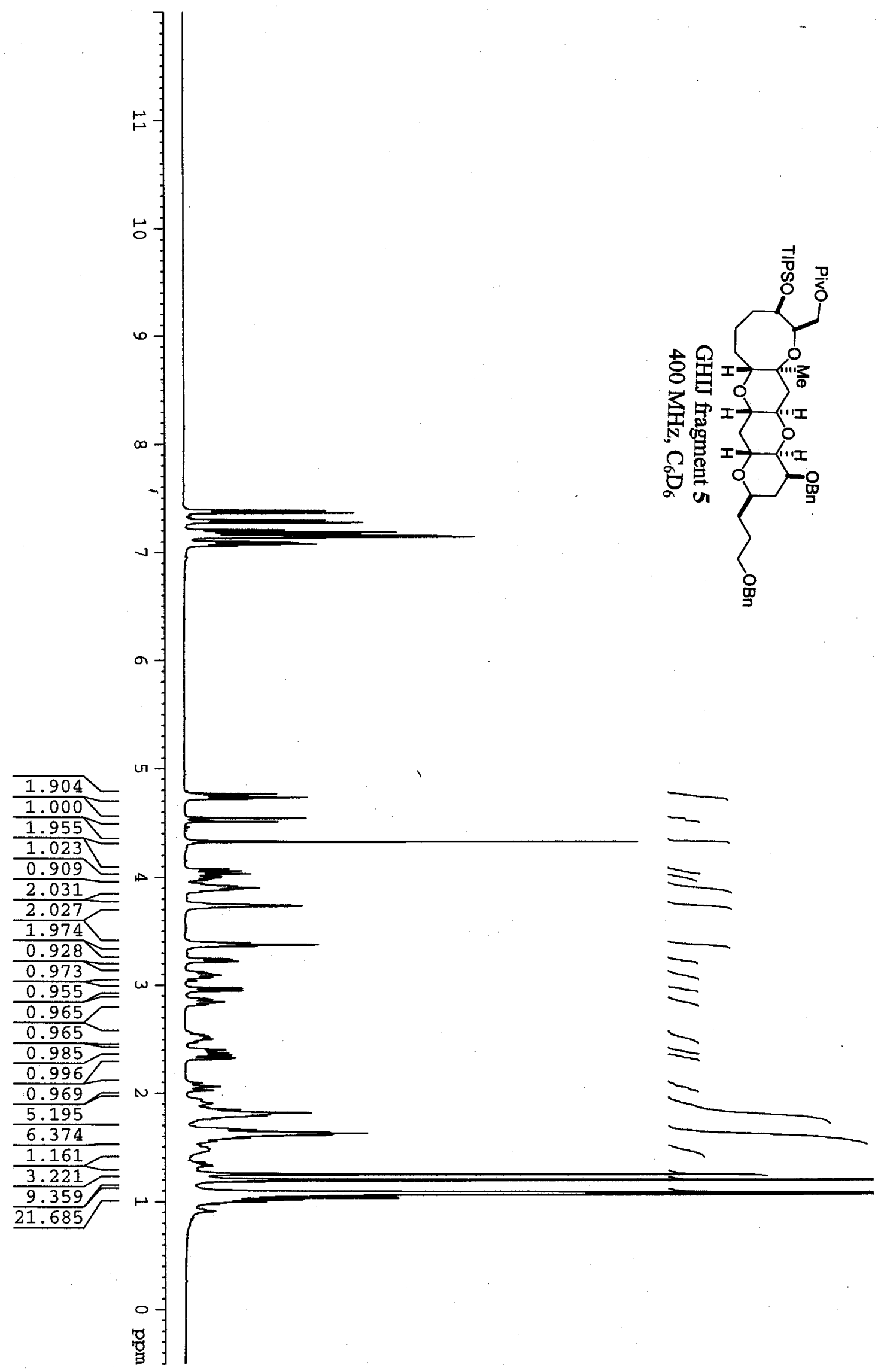




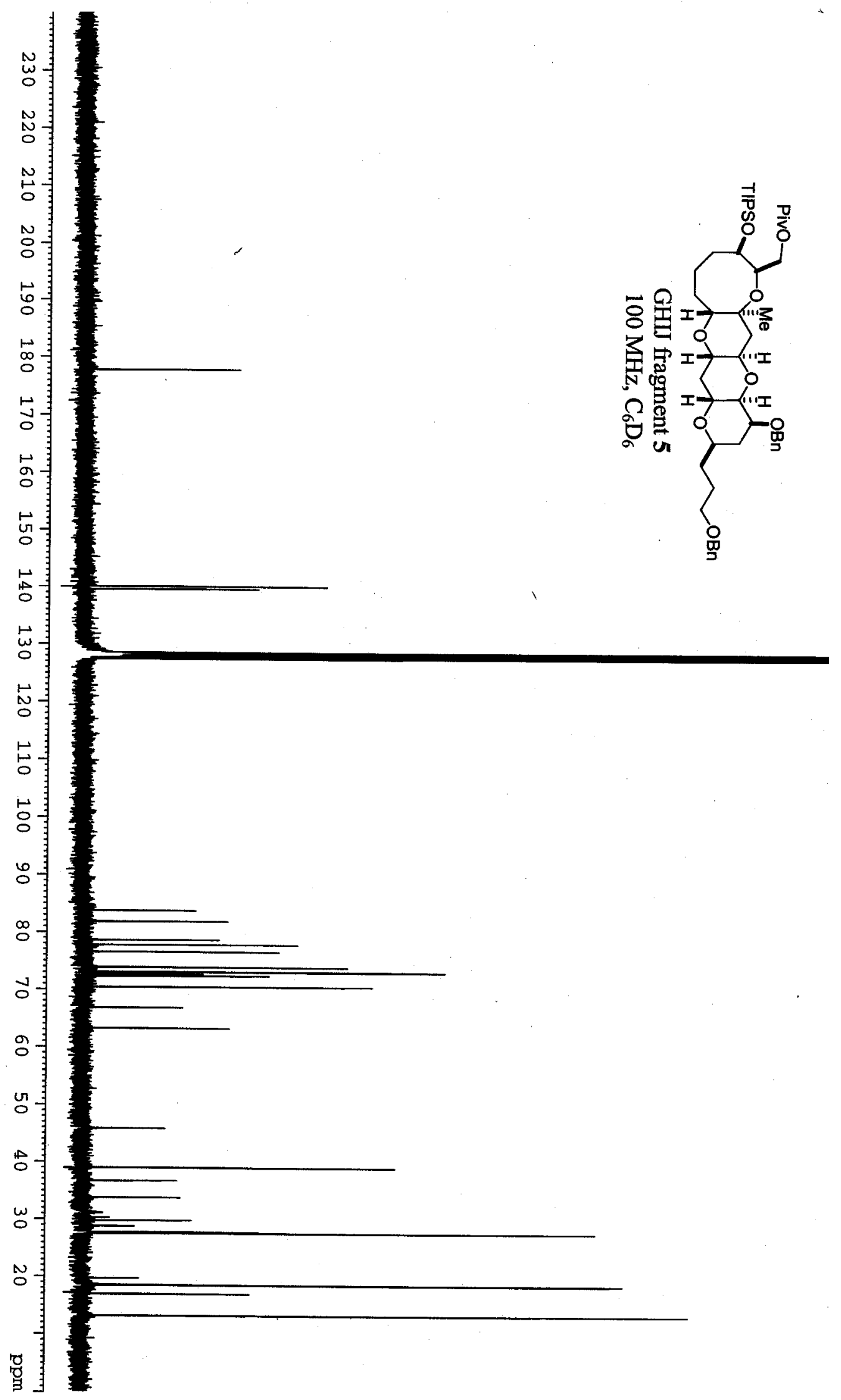




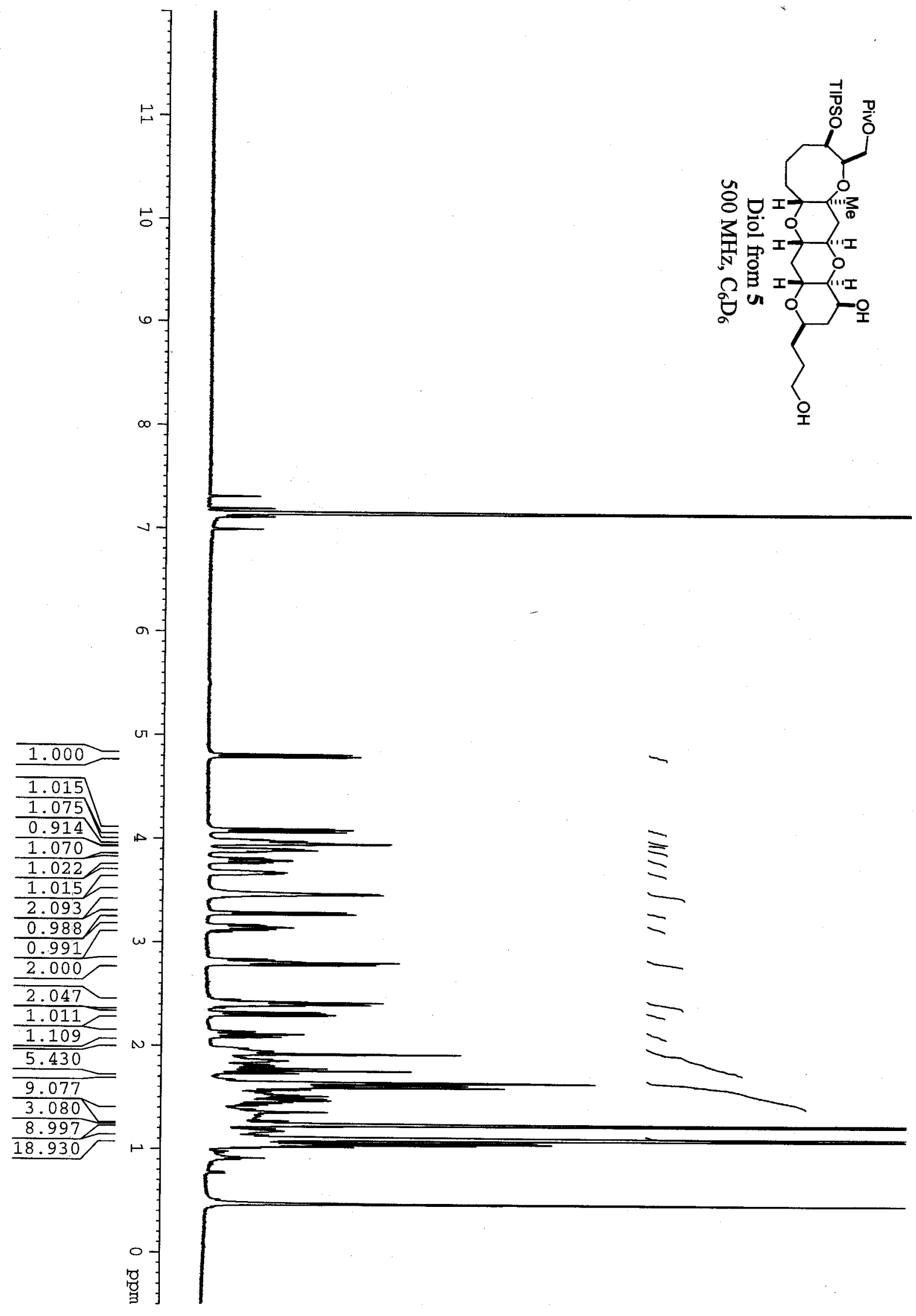




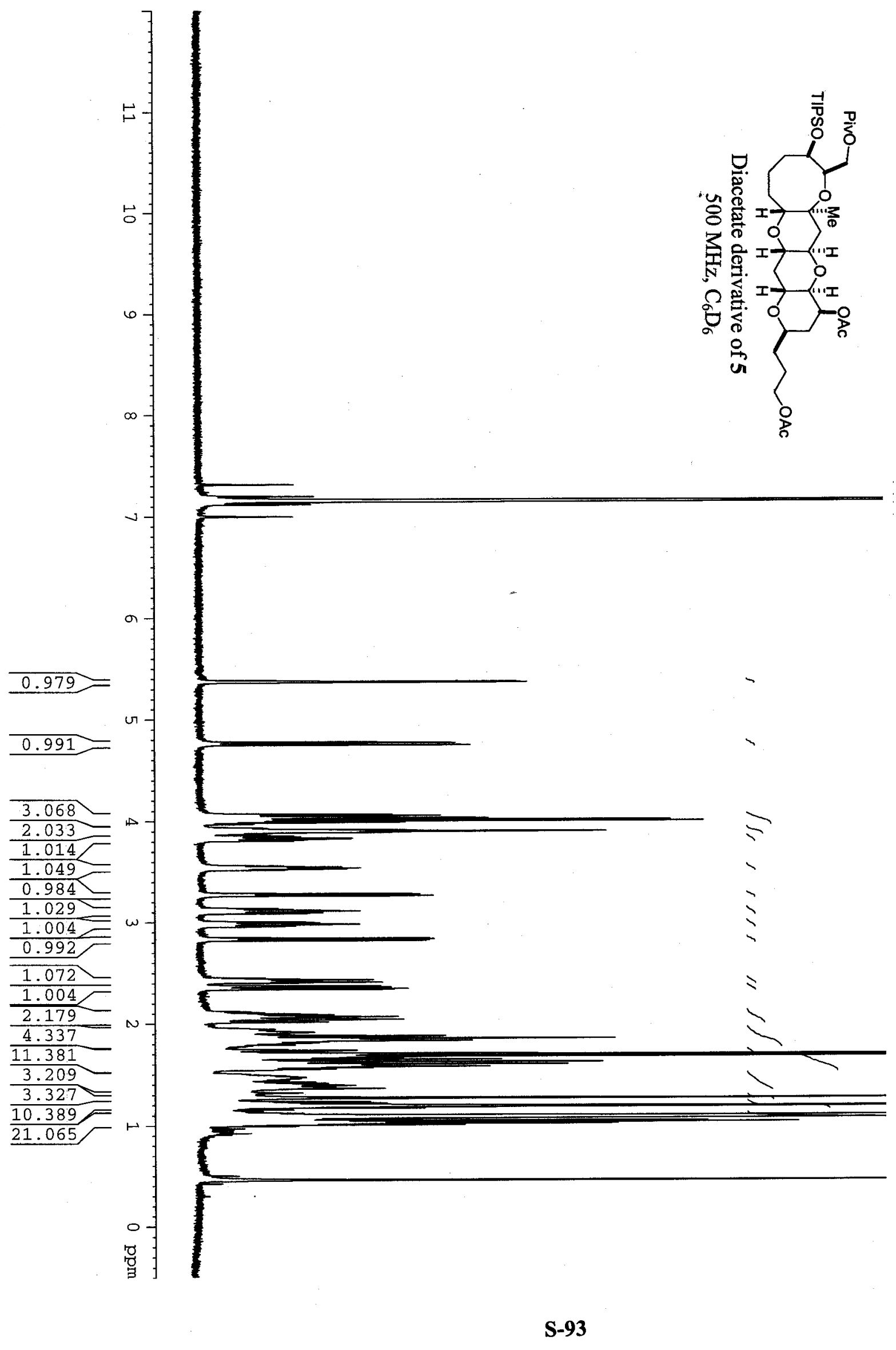




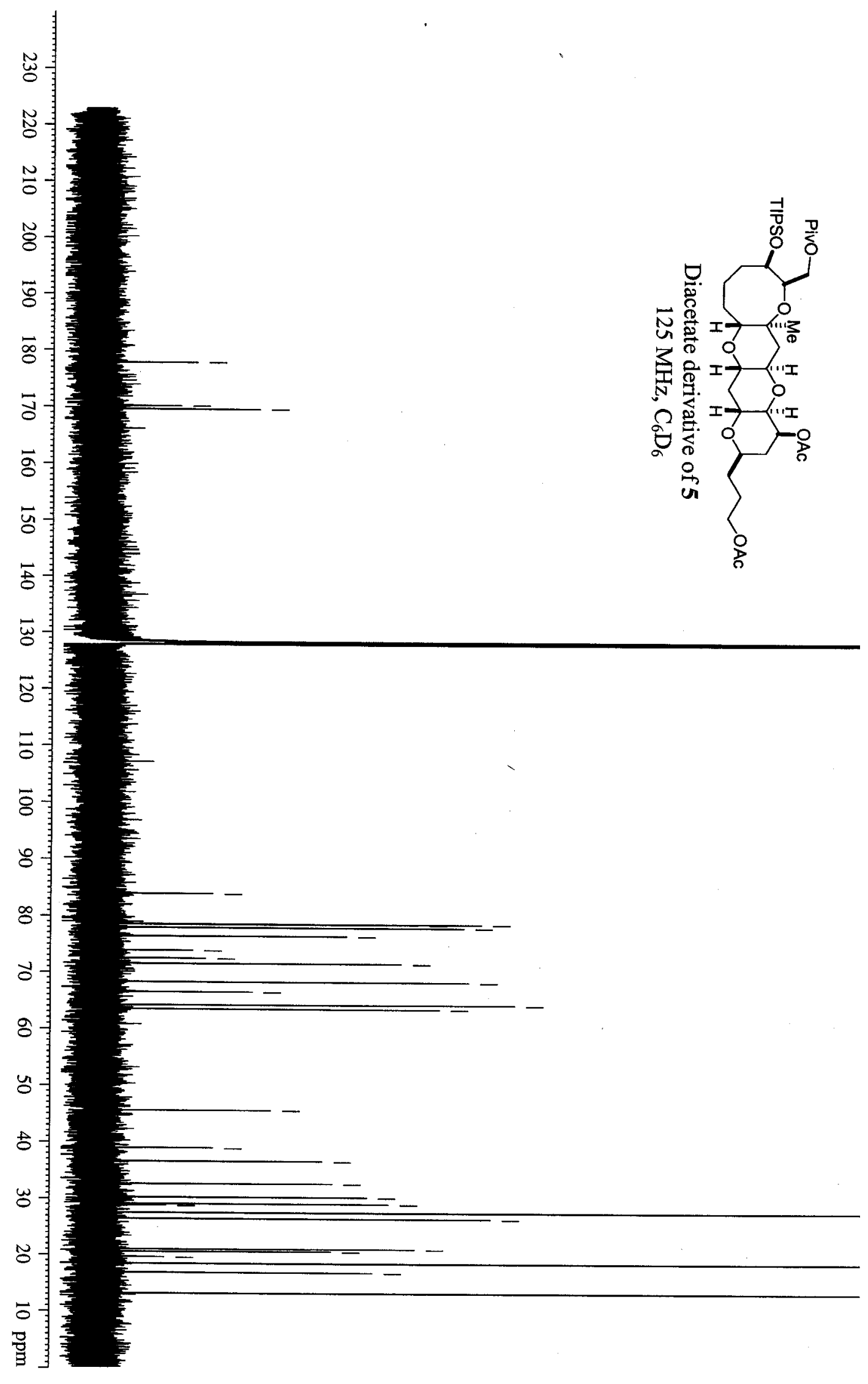




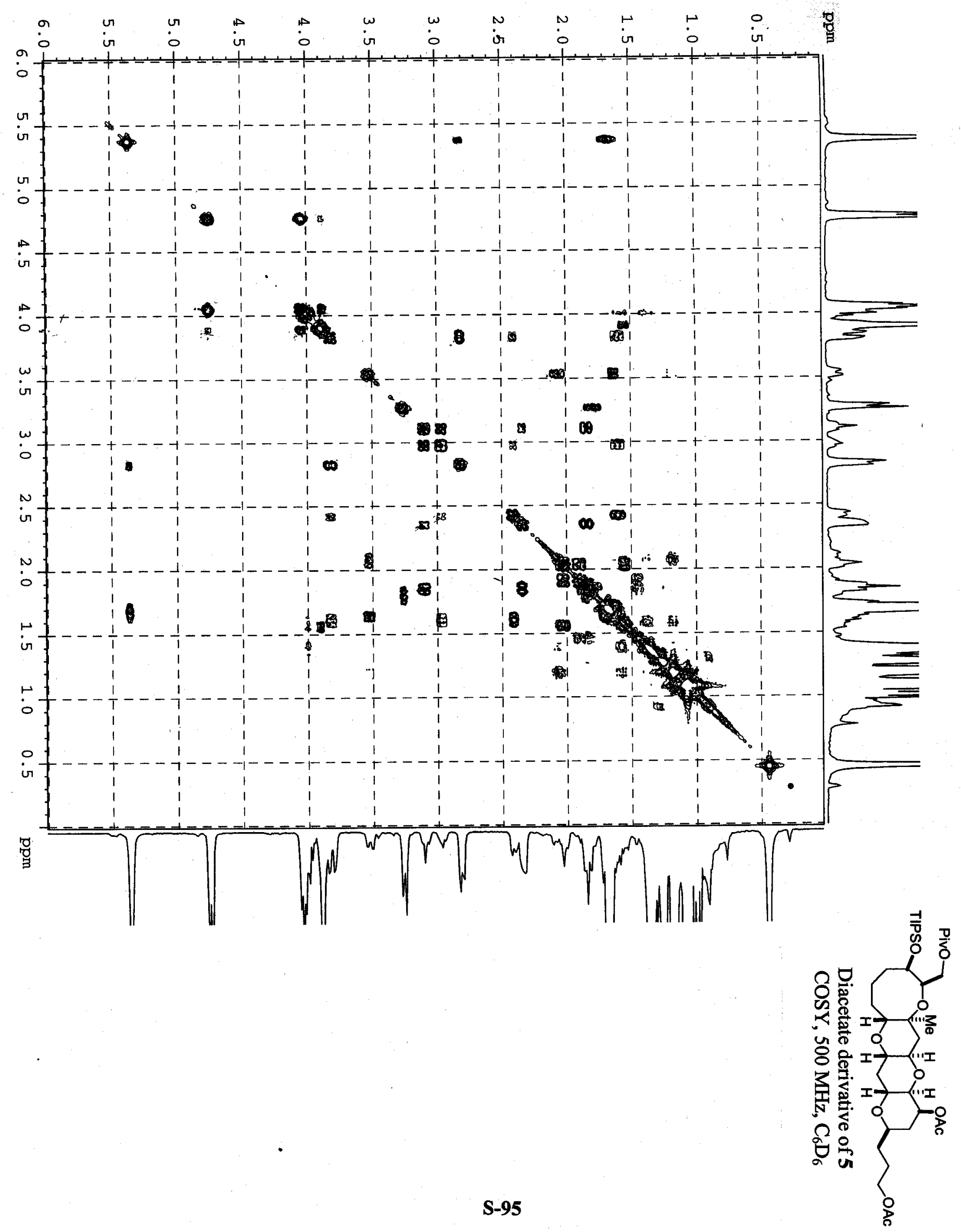



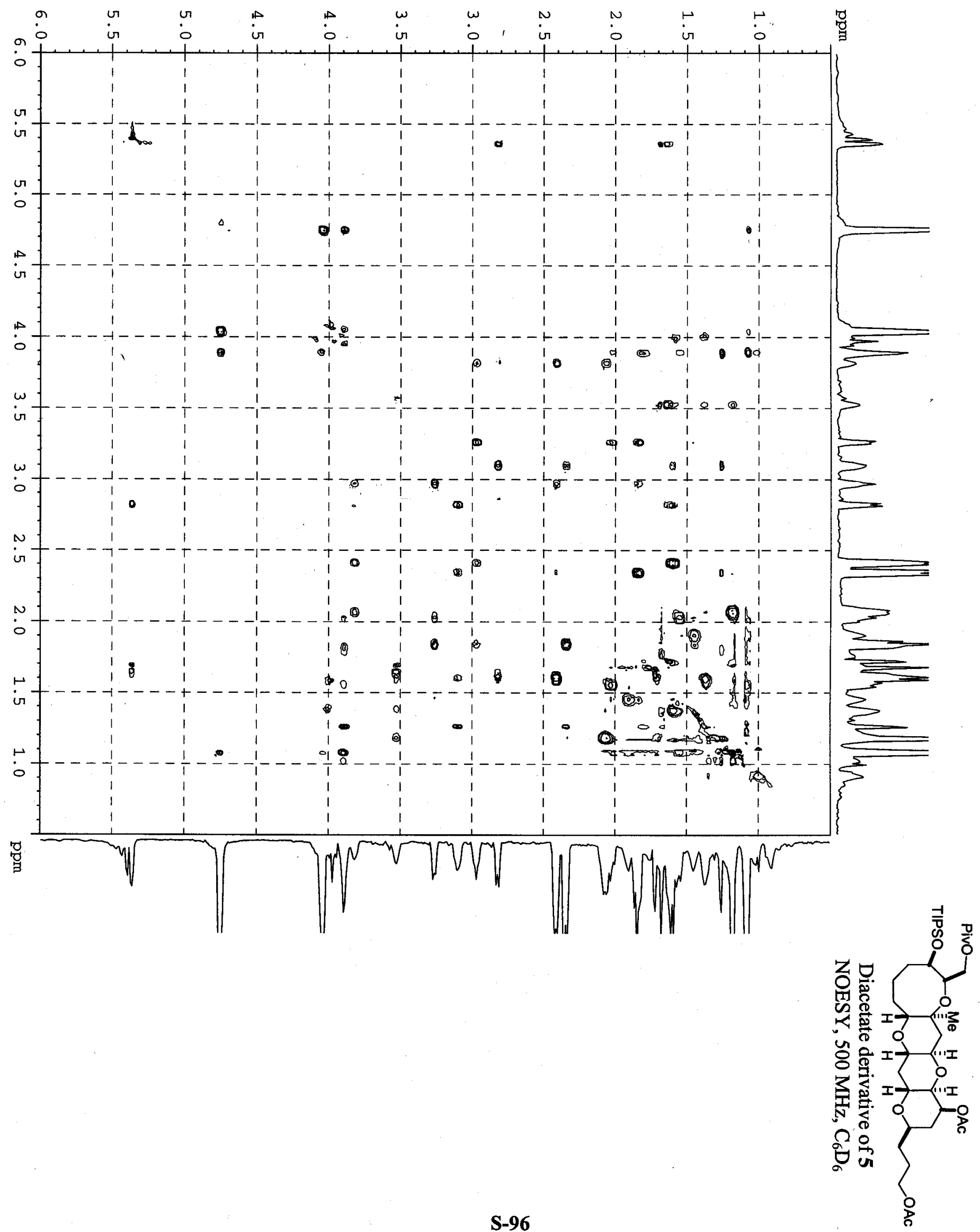